\title{
Archipel
}

ARCHIPEL Études interdisciplinaires sur le monde insulindien

$101 \mid 2021$

Varia

\section{Old Sundanese Inscriptions: Renewing the Philological Approach*}

Inscriptions anciennes en soundanais : renouveler l'approche philologique

\section{Aditia Gunawan et Arlo Griffiths}

\section{(2) OpenEdition}

\section{Édition électronique}

URL : https://journals.openedition.org/archipel/2365

DOI : 10.4000/archipel.2365

ISSN : 2104-3655

\section{Éditeur}

Association Archipel

\section{Édition imprimée}

Date de publication : 30 June 2021

Pagination : 131-208

ISBN : 978-2-910513-85-6

ISSN : 0044-8613

\section{Référence électronique}

Aditia Gunawan et Arlo Griffiths, "Old Sundanese Inscriptions: Renewing the Philological Approach* ", Archipel [En ligne], 101 | 2021, mis en ligne le 02 juin 2021, consulté le 01 juillet 2021. URL : http:// journals.openedition.org/archipel/2365; DOI : https://doi.org/10.4000/archipel.2365 


\section{ADITIA GUNAWAN* \& ARLO GRIFFITHS**}

\section{Old Sundanese Inscriptions: Renewing the Philological Approach***}

\section{Introduction}

Old Sundanese is known to us today thanks to the survival of documents using this language, whether written on leaves of the gebang or lontar palms, on bamboo strips, on tree bark (daluwang), on metal plates or on stone. ${ }^{1}$ The number of such metal or stone inscriptions in Old Sundanese is quite limited, when

* Staff philologist at Perpustakaan Nasional Republik Indonesia (Jakarta), currently $\mathrm{PhD}$ student at the École Pratique des Hautes Études and associated member of UMR 8170 Centre Asie du Sud-Est (both in Paris).

** Professor of Southeast Asian History at the École française d'Extrême-Orient (Paris) and member of UMR 5189, Histoire et Sources des Mondes Antiques (Lyon).

*** The research for this article was begun shortly after we had met each other in Jakarta in 2012, but put on hold again in the course of 2014, and then resumed only in 2019 when Aditia Gunawan came to Paris for his doctoral studies as member of the project DHARMA "The Domestication of 'Hindu' Asceticism and the Religious Making of South and Southeast Asia," funded from 2019 through 2025 by the European Research Council (ERC) under the European Union's Horizon 2020 research and innovation program (grant agreement no 809994). On the project, see https://dharma.hypotheses.org. We gratefully acknowledge the helpful comments on drafts of this article received from Atep Kurnia, Véronique Degroot, Tom Hoogervorst, Wayan Jarrah Sastrawan and Titi Surti Nastiti. 1. Edi S. Ekadjati 1996; Munawar Holil \& Aditia Gunawan 2010; Aditia Gunawan \& Griffiths 2014; Aditia Gunawan 2015; Aditia Gunawan \& Evi Fuji Fauziyah 2021.

1. Edi S. Ekadjati 1996; Munawar Holil \& Aditia Gunawan 2010; Aditia Gunawan \& Griffiths 2014; Aditia Gunawan 2015; Aditia Gunawan \& Evi Fuji Fauziyah 2021. 
compared to the material available in the other epigraphically attested languages of Indonesia, viz. Old Malay, Old Balinese and especially Old Javanese. But the documentary situation is in a way more favorable than the case of Old Malay (where very few non-epigraphic texts survive to complement a small, though ancient, epigraphic corpus) ${ }^{2}$ and by comparison with that of Old Balinese (for which no non-epigraphic texts survive at all). Indeed, besides the tiny corpus of epigraphic Old Sundanese texts, there is a much more sizable corpus of texts transmitted on perishable materials in a variety of genres (belles-lettres, outlines of religious doctrine, chronicles, technical treatises). At the same time, it should be noted that, by comparison with the other mentioned languages, the Old Sundanese material is several centuries younger, as the oldest dated manuscript was copied in $1518 \mathrm{CE}$, while the oldest inscription may date to the 14th century.

The pre-Islamic Sundanese writing tradition was diglossic as well as digraphic, involving textual production and reproduction in the vernacular (Old Sundanese) as well as in a supralocal language (Old Javanese), making use of two rather distinct script types. In manuscripts, we encounter either "Old Sundanese characters," which have never been used outside the Sundanesespeaking region as far as we are aware, or "Old Western Javanese quadratic" characters (slightly adapting the term proposed by Acri 2017: 48), sometimes denoted as aksara buda (literally "Buddhist characters") and also known as aksara gunung ("mountain characters") - the two types are illustrated in figs. 5 and 6 below. The former type was generally used for carving characters into leaves of the lontar palm with a stylus to be inked afterwards. The second type, on the other hand, was written onto leaves of the gebang palm with a kind of pen. There is a strong tendency, in the Sundanese manuscript culture, to use the Old Sundanese script for writing on lontar in the Old Sundanese language, while reserving the Old Western Javanese quadratic script for writing on gebang and in the Old Javanese language, although there are some exceptions to this pattern. The degree to which these script types can be distinguished in the epigraphic context is a question to which we will return below.

The pre-Islamic West Javanese manuscripts only started to become known and studied from the middle of the 19th century onwards. ${ }^{3}$ The existence of inscriptions in West Java, on the other hand, and notably of the Batutulis at Bogor, had already been known to Dutch observers from the late 17th century onward. ${ }^{4}$ While most of the epigraphic corpus assembled in this article had already been published by the end of the 19th century, and post-Independence

2. Waruno Mahdi 2005; Griffiths 2018, 2020a and 2020b, Clavé \& Griffiths forthcoming.

3. See Munawar Holil \& Aditia Gunawan 2010.

4. See de Haan 1910-1912, vol. I, p. 67* and p. 30, for the first explicit reports on the Batoetoelis in 1690 and 1710; see also vol. II, bijlagen XV and XXII. Based on the sources presented by de Haan (which Atep Kurnia has kindly drawn to our attention), Saleh Danasasmita (2006: 11-41) has summarized the early history of Dutch encounters with the antiquities at Bogor. 
Indonesian scholars have continued to make occasional contributions, this field of study can hardly be said to have reached maturity. Some inscriptions are very often referred to in the scholarly literature, not to mention popular publications and schoolbooks, because they contain the dating or mention of the Sundanese kings around whom a Sundanese sense of history and identity has been constructed. Other inscriptions have not attracted much attention at all. There is moreover a very strong tendency for uncritical repetition of received interpretations. And the results of Old Sundanese epigraphic research achieved so far still leave many problems without a compelling solution.

The challenges to interpretation lie, first, in the unsatisfactory quality of the reproductions of the inscriptions that have been used by scholars so far to decipher them, and, second, in insufficiencies in our understanding of the language. In the near-total absence of any study of Old Sundanese grammar and lexicon, most scholars have tended to interpret the ancient language exclusively through the lens of modern Sundanese. A systematic review of Old Sundanese linguistics has only started to be conducted by J. Noorduyn \& A. Teeuw in their 2006 book, but even this seminal work was ignored in subsequent studies of Old Sundanese epigraphy.

Finally, the fact that so little is known about the historical and cultural contexts in which the Old Sundanese inscriptions were produced imposes severe limitations on their interpretation. In this regard, using contemporary external sources, in Javanese, Malay, Sanskrit or even European languages, can yield important new insights - and this is true a fortiori for contemporary sources from the Sunda region itself. As it happens, the development of Old Sundanese philological research in the last few decades has made textual sources in Old Sundanese much more widely available now than they were even as recently as the 1970s. These documents have much to offer as comparative material for the epigraphist's effort to interpret the inscriptions but were either unavailable to previous researchers or remained underutilized.

This article's main objective, therefore, is to present new editions of Old Sundanese inscriptions, based on direct reading from the original artefacts and on newly made photos and estampages, and to interpret the contents of these inscriptions by making systematic use of Old Sundanese sources preserved in manuscripts, along with any other documentation that seems relevant. We believe that this methodological renewal can provide a robust foundation for the further historical and linguistic exploitation of the epigraphic data.

Given this objective, we naturally limit ourselves to the inscriptions written in Old Sundanese, while excluding inscriptions in other languages, such as Old Javanese and Old Malay, although a small number of them have been found in the Sundanese-speaking region. ${ }^{5}$ For the same reason, and others, we also give

5. Non-Sundanese inscriptions are also found in West Java from the 6th century onward, for instance seven inscriptions of king Pūrṇavarman in Sanskrit (Vogel 1925), the Sang Hyang Tapak (Pleyte 1916) and Mandiwunga inscriptions (Hasan Djafar 1991, Titi Surti Nastiti 


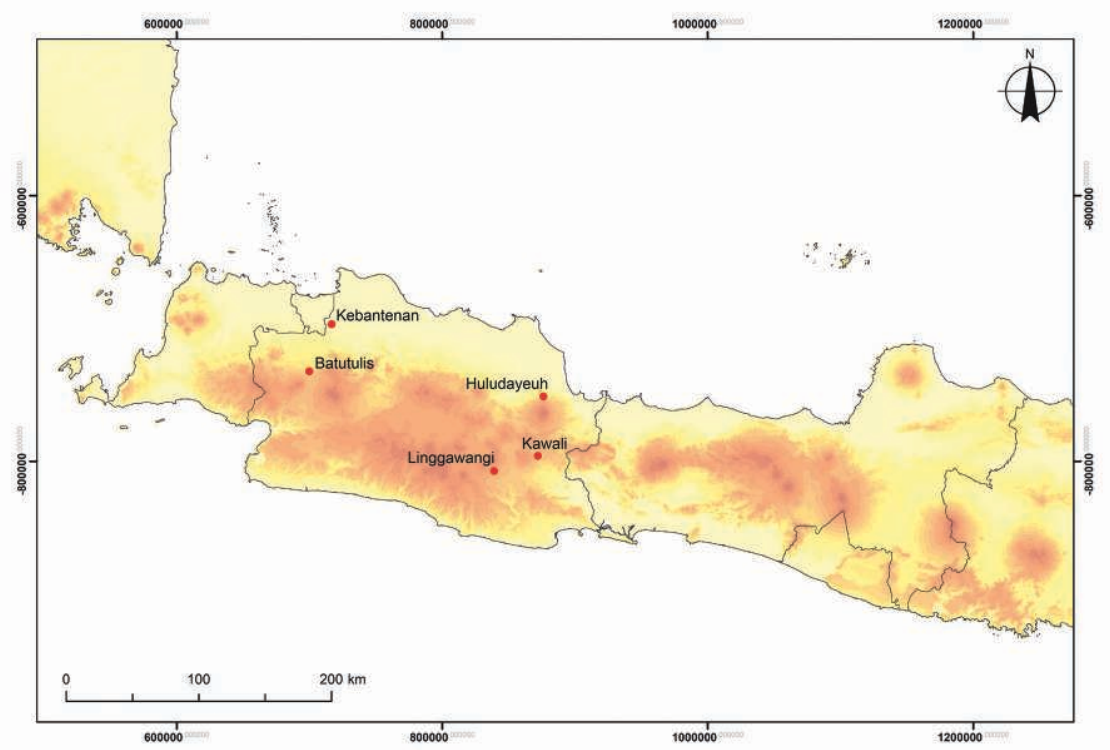

Fig. 1 - Geographic Distribution of the Old Sundanese inscriptions. Map by Chea Socheat.

relatively little consideration here to the archaeological contexts of the inscribed artefacts, although this is certainly a topic deserving systematic enquiry.

\section{Romanization and other philological conventions}

No international or even domestic Indonesian consensus has been reached so far on how to convert the written form of Old Sundanese documents into Roman script, that is, on how to transliterate the originals. This is as true for Old Sundanese epigraphy as it is for texts transmitted in manuscripts. In our discussion of Sundanese script, we will use the current Sundanese (rather than any corresponding Javanese or Sanskrit) terms for the various markers that can be applied to a basic aksara in order to modify or remove an inherent vowel $a$ or add a consonant before or after the vowel, since many Sundanese scholars understand and apply them in an academic context. ${ }^{6}$

\& Hasan Djafar 2016, Hasan Djafar et al. 2016: 99-104) in Old Javanese, the Kebonkopi inscription in Old Malay (Bosch 1941, Hasan Djafar 1991), Buddhist mantra inscriptions found at the site of Batujaya (Hasan Djafar 2010, Griffiths 2014b: 155-156), minor items found at other sites such as the Sadapaingan kentongan (Griffiths \& Lunsingh Scheurleer 2014), and the recently discovered Jambansari inscription, which is an abecedary for the Indian alphabet (one recognizes the sequence ya-ra-la-va, etc.) although its editors do not seem to have realized this (Titi Surti Nastiti \& Hasan Djafar 2016: 111-112).

6. These terms may go back to the time that (modern) Javanese script was adapted and came to be the dominant writing system in the Sunda region, no later than the 16th century. Some of 


\begin{tabular}{|c|c|c|c|}
\hline Sundanese & Javanese & Sanskrit & Sundanese UNICODE \\
\hline panghulu & wulu & & 7 \\
\hline pamepet & pepet & & ? \\
\hline panyuku & suku & & 7 \\
\hline panéléng & taling & & $\mathrm{z}$ \\
\hline panolong & tarung & & z \\
\hline panyecek & cecak & anusvāra & 0 \\
\hline pangwisad & wignyan & visarga & II \\
\hline panglayar & layar & repha & $\mathrm{v}$ \\
\hline panyakra & cakra & & $\sim$ \\
\hline pamingkal & pengkal & & r \\
\hline pamaéh & pangkon & virāma & $z$ \\
\hline pasangan & pasangan & & $\begin{array}{c}\mathrm{C}_{\mathrm{z}} \\
\mathrm{zz}\end{array}$ \\
\hline
\end{tabular}

Table 1 - Correspondences of Sundanese to Javanese and Sanskrit terms for markers applicable to consonant aksaras. Note that we show the only two pasangans so far admitted in the Unicode block for Sundanese script (https://www.unicode.org/charts/PDF/U1B80.pdf).

these terms (pamaihan, téléng, tolong, etc.) already appear for instance in Roorda's preface to the Dutch-Malay-Sundanese dictionary compiled by Andries de Wilde (1841). Subsequently, primers for the adapted Javanese script, better known as Cacarakan, as well as grammar books started to use terms rendered more pedagogical through the application of prefix $p a N-$, for example panéléng (from téléng), panolong (from tolong), pangwisad (from wisad), etc. (see e.g. Oosting 1884, Coolsma 1904, Nita Sasmita 1955). Since the 2000s, the Sundanese script that is taught in schools is no longer Cacarakan, but a standardized set of aksaras modeled after those found in pre-Islamic manuscripts, whereas the terms have been maintained. The terms that were in use at the time of production of those pre-Islamic manuscripts were different. This may be inferred from the terms preserved in the poetological manual Candrakirana, one of the known manuscripts of which comes from West Java. See Lokesh Chandra (1997: 154-156) and Zakariya Pamuji Aminullah (2019, §3.12). 
Early researchers such as K. F. Holle and C. M. Pleyte, for example, did not attempt to maintain a one-to-one correspondence between the graphic elements of the original and the Roman target script. These two scholars did not (or did not systematically) distinguish consonant $\dot{n}$ from panyecek $\dot{m}, h$ from pangwisad $h$, dental $d$ from retroflex $d$. They never gave explicit representation to the pamaéh, took the liberty of ignoring many punctuation marks and of imposing a distinction between the phonemes of Modern Sundanese that are nowadays spelt $e$ and $e u$, whereas the original documents make no such distinction. Post-independence scholars, especially Hasan Djafar and Titi Surti Nastiti, have begun to apply greater rigor in dealing with these phenomena, for example by distinguishing the full consonant aksara $\dot{n}$ from the panyecek (represented by them respectively as $\dot{n}$ and $\eta$ ), the full aksara $h$ from the pangwisad, independent vowels (marked by them with ${ }^{\circ}$ before the vowel in question) from vowels that are part of a consonant-initial syllable, and explicitly rendering the pamaéh (with a closing parenthesis or with a slash). However, these researchers have not remained consistent in their transliteration system from publication to publication, have never distinguished between $d$ and $d$, and have continued to impose on the data a distinction between so-called pamepet $ə$ and paneuleung ə: (see §3.1.1).

In the new editions of the inscriptions offered here, we apply the transliteration conventions formulated by Balogh \& Griffiths (2020), i.e. largely the ISO standard 15919 but with some adaptations, among which the use of capital letters for aksara vowels. Particularly noticeable differences between our system and all predecessors is our use of $v$ and $\dot{m}$, as per ISO 15919, instead of $w$ and $\eta$, our systematic representation of pamaéh with a median dot, our use of : to transliterate cases where panolong is intended as a marker of vowel length (see §3.1.7), and our exclusive use of a for pamepet (not included in ISO 15919). It may not be useless to insist on the fact that these are strictly choices of transliteration, and do not imply any different insight into how Old Sundanese was actually pronounced. When citing readings of previous scholars, we adapt their system of transliteration to ours, although this sometimes involves guessing what their intentions were. Many scholars in the past have, for instance, not indicated the pamaéh, but some have, using other representations than our $\cdot$ If a reading implies that the editor observed a vowel killer, then we represent it in our citation of that reading. Mutatis mutandis, we apply the same method to other instances that pertain solely to differences between the transliteration schemes of previous scholars and our own.

By contrast with our application of strict transliteration to the texts of the inscriptions, we apply a "loose transliteration" to passages quoted from Old Sundanese and Old Javanese transmitted, i.e., non-epigraphic, texts (Balogh \& Griffiths 2020: 8). This implies a normalization of orthography on several points: merging panyecek $\dot{m}$ into $\dot{n}$, pangwisad $h$ into $h$, simplifying non morphemic gemination ( $\dot{m} \dot{n}$ to $\dot{n}, h h$ to $h$, etc.), interpreting any consonant $\mathrm{C}$ 
bearing pamingkal and panghulu as Ciya, interpreting any consonant $\mathrm{C}$ that bears pasangan va as Co depending on the word that is intended, and removing all instances of the pamaéh. When we cite modern Sundanese data, or when Old Sundanese names appear in our English translations, we follow Modern Sundanese spelling norms for the former and adjust the spelling to those norms for the latter. ${ }^{7}$

In our editions below, we use the follow editorial symbols:

\begin{tabular}{|c|c|}
\hline (xyz) & reading unclear \\
\hline [xyz] & lost due to damage to the support \\
\hline $\begin{array}{l}\langle x y z> \\
0\end{array}$ & $\begin{array}{l}\text { omitted by scribe, needing to be supplied } \\
\text { binding hole }\end{array}$ \\
\hline - & $\begin{array}{l}\text { one illegible aksara } \\
\text { panéléng read with first aksar }\end{array}$ \\
\hline
\end{tabular}

In our translations, words in square brackets [...] are our additions to facilitate English sentence construction, while explanatory additions are placed in parentheses (...).

\section{From transliteration to interpretation}

\subsection{Writing system and issues of spelling}

When comparing Old Sundanese inscriptions and manuscripts, it becomes clear that all these documents deploy what is basically a single writing system and follow the same patterns of spelling - this fact probably reflects their production roughly during the same period, about the 14th through 16th centuries, and by the same scribal milieux. It is important to take due account of these features in order to make the pass from the "raw" transliterated textual data to the more abstract level of deciding which words, with which affixes, were intended in which meanings.

\subsubsection{Absence of any spelling distinction corresponding to $M d S$ e and eu}

If one looks at the readings of the inscriptions published by previous scholars, one gets the impression that the authors of the inscribed texts distinguished between $ə$ (generally transliterated as $\breve{e}$ or $e$ ) and $ə$ : (generally transliterated as $\ddot{o}$ or $e u$ ). But in reality only one marker is found in the corresponding passages, namely the pamepet which we transliterate as a (see appendix). Pleyte (1914: 266) and Noorduyn (1962: 376) had already pointed out that the Old Sundanese script used in manuscripts does not distinguish between $ə$ and $ə$ :, and the same issue has been discussed with several further

7. We use Palanggeran Éjahan Basa Sunda, compiled by Jurusan Pendidikan Bahasa Daerah, Universitas Pendidikan Indonesia (2008). 
references by Teeuw in his introduction to the work of Noorduyn on three Old Sundanese poems (Noorduyn \& Teeuw 2006: 19-20). Not all of the authorities referred to by Teeuw are, in our view, reliable, and it must be stated once and for all that Old Sundanese script does not make a distinction corresponding to $\operatorname{MdS} e$ and $e u$. The paneuleung ( ) admitted in the Unicode version of Sundanese script has no basis in the historical documents after which that script has been modeled. The imposition of this distinction is obviously based on the phonology and spelling habits familiar from MdS. However, we do not know how Old Sundanese was pronounced at the time of the production of the documents we have, and it seems better to avoid the risk of anachronistic phonological interpretation by maintaining a one-to-one correspondence between the graphic elements of the original and the target scripts.

\subsubsection{Spelling of /Ciya/ as Cya}

A remarkable spelling feature found both in inscriptions and in manuscripts is the addition of the panghulu to the consonant with pamingkal, so that logically one must transliterate it as $C y i$, although it is quite evident that the vowel is actually to be pronounced before the pamingkal, to yield Ciya. Editors of Old Sundanese texts were aware of this tendency and have generally represented such aksaras as Ciya, without commenting on the resulting inconsistency with general transliteration patterns. However, Undang A. Darsa \& Edi S. Ekadjati (1995) initiated its representation as Cyi in their edition of the Fragmen Carita Parahyanan and Carita Parahyainan, and it is this solution that has subsequently been applied in publications of Old Sundanese texts. Thus, we find spellings like rahyim (BaTu.5) which should be understood as rahiyain, sam hyim (BaTu.7) as sain hiyain, ñyin $(2 \times$ BaTu.7) as ñiyan, syi (Kawa1.2) as siya. Besides such characteristically Sundanese spellings, we also encounter ones that appear more "normal" to anyone familiar with the spelling system found in Old Javanese inscriptions and manuscripts from Java and Bali: rahyam (Keba1.1r1-2), sam hyam (Kawa4), and sya (HuDa.3\&4). One inscription (Kawa4) combines the two in the phrase sam hyim limga hyam, suggesting the arbitrary nature of the choice.

\subsubsection{Spelling of hiatus vs semivowel}

Another feature that seems noteworthy, among other reasons because it is superficially similar to the spelling of /Ciya/ with Cyi discussed in the preceding paragraph, is the scribal freedom to choose between spellings with hiatus ( $\mathrm{Cia}, \mathrm{Cua}$, etc.) or with semivowels (Cya, Cva, etc.). In the epigraphic corpus, we only find two minimal pairs: the same toponym Pakuan is spelt either with hiatus (pakuAn, Keba1.1r4) or with semivowel (pakvan, BaTu.3\&4, Keba2.1r2, Keba4.1, HuDa.3); likewise, we find both ia (nahəriAnan, Keba4.3\&5, Keba5.4\&5) and ya (nahrryanan, Keba1.1v2, Keba2.1r4, Keba3.1r4), but we also have niahrriyanan 
(Keba4.4 \& Keba5.6). The same kinds of variation are commonly observed in Sundanese manuscripts. The semivowel $y$ is commonly used to bridge the hiatus between a front vowel and $a$, as in ea (papakeyan for papakean, SD.46) or ia (siyan for sian, CRP.508). On the other hand, the semivowel $v$ is commonly used to bridge the hiatus between a back vowel and $a$, as in ua (luvar for luar, CP 66). We also, though rarely, find the use of $y$ to bridge the hiatus ua, i.e., uya instead of ua/uva/va in karatuyan (Keba4.7), a phenomenon of which we know just one other occurrence, viz. in a lontar manuscript belonging to Abah Cahya from Bandung (fol. 3r), which contains the words kəbam kakaduyan, i.e. kəmbain kakaduan "flower of the kakaduan tree." We also exceptionally find iva (Kawa6.4) for MdS ieu, more commonly spelt iyz in OS manuscripts. Thus it seems that there was a certain interchangeability between the semivowels $v$ and $y$.

\subsubsection{Notation of consonant clusters}

Old Sundanese script tends to give the impression that characters were engraved between parallel horizontal lines. Only very rarely do scribes take recourse to the subscript consonants - pasangan in the broad sense - that are such an important feature of Javanese and Balinese scripts. The only ones which are common in Old Sundanese script are the panyakra $(r)$, the pamingkal (y), and the pasangan $v$. Nevertheless, Sundanese is not and has never been a language free of consonant clusters. Rather than making use of the device of pasangan, Sundanese scribes generally preferred to express consonant clusters by writing their constituents sequentially from left to right and applying pamaéh to the first. A relevant example from the inscriptions is nis.kala vas.tu (BaTu.5) instead of niskala vastu. We have only found the following pasangans in the epigraphic corpus: $c$ in pañca (BaTu.6) and kañcana (Keba1.1r2, 1r3), $n$ in Avighnam (Keba1.1r1), b in sambava (Keba1.1v1, Keba2.1r3) and timbam (Keba1.1v3), and $k$ in niskala (Keba1.1r2). ${ }^{8}$ We refer to the appendix for the respective shapes.

\subsubsection{Gemination and degemination}

It is frequently observed that consonants are doubled with or without morphological trigger. Gemination of the velar nasal $\dot{n}$ is expressed by adding $\dot{m}$ to an aksara preceding $\dot{n}$, as in bənaminim (Keba2.1v4), laraminan. (Keba2.1v3); likewise, gemination of glottal fricative $h$ is expressed by inserting $h$ before $h$, as in palulurahhan (2×, Keba4.3 and Keba5.3), paLLmahhhan (Keba4.3), dipaEhhhan. (Keba3.1-2), maḥharaja (HuDa.2) rah̆hayu (Kawa1a.9). Gemination of other consonants requires use of pamaéh on the first, as in sugan'n aya (Keba4.2), mipatikan'n ikam kala (HuDa.10-11),

8. Based on his study of the manuscripts held in kabuyutan Ciburuy, Rahmat Sopian (2020: 133, table 8 ) shows that every consonant in that corpus has a pasangan form. 
devasasan·na (Keba1.2r3) and bvan'na (HuDa.6). As these examples show, there is a strong propensity for gemination to occur at morpheme boundaries both within and between words, but the examples of gemination within words of Sanskrit origin illustrate that the phenomenon may occur even when there is no real morpheme boundary. This phenomenon seems to have been inherited by the Sundanese writing tradition from the Javanese, where it occurs from the oldest inscriptions onward, right down to the Balinese manuscript tradition of recent centuries. By contrast, we find only one occurrence of the opposite phenomenon, degemination, in the small corpus of OS inscriptions, namely disusuku for di-susuk $k u$ in LiWa.3. But this phenomenon is rather widespread in the OS manuscript tradition, for instance nəbukaram for nəbuk karain (BM.1005), sacuduka bukit for sa-cu<n〉duk ka bukit (BM.705), natvahkəna sabda for natvahkən na sabda (KP.597). Nevertheless, even in manuscripts, it is the exception rather than the rule: it seems to occur with relatively greater frequency in the case of consonants $k$ and $n$, and much less so with other ones, although instances are by no means unknown: $l$ (mañcaluhur for mañcal luhur, SD.67), $m$ (patimtimaneh for patintim maneh, KP.368), $p$ (pet hdapet sabda for pet hdap pet sabda, KP.470), s (titisovara for titis sovara, PR.67v), $t$ (kasabutumgal for ka-sabut tungal, JMP.3).

\subsubsection{Non spelling of syllable-final nasals}

A pervasive feature of OS spelling, no doubt related to phenomena observed in Javanese, is the very frequent absence in spelling of a nasal in intervocalic clusters of homorganic nasal plus palatal, dental or bilabial stop; absence of velar nasal before intervocalic $s, g$ or $k$ due to omission of expected panyecek; or, also due to panyecek omission, absence of velar nasal at word end. These phenomena have been recognized by the editors of Old Sundanese texts. ${ }^{9}$ We follow our predecessors in supplying unspelled nasals that are expected on philological and/or linguistic grounds. In some cases, the epigraphic corpus itself contains minimal pairs supporting the assumption that a nasal is to be supplied: e.g., hagat (Keba4.4) compared to hamgat (Keba2.1r4\&5), kaca:na (BaTu.6) to kañcana (Keba1.2\&3), metaAn (Keba4.6) to mentaAn (Keba1.1r4-2v1). In other cases, the need to supply a nasal can be inferred from spellings found in manuscripts: e.g., nahali<m>pukən (HuDa.5-6) with reference to halimpu (SKK.3) or nirñ cak. (Kawalb.4) to katiñcak (BM.221). If no such OS supporting evidence is available, we have to assume that comparison with MdS vocabulary as recorded in dictionaries is a reliable guide

\footnotetext{
9. For instance, Atja (1970) in his edition of the Carita Ratu Pakuan states that "Ejaan yang dipergunakan oleh penulis naskah tentu saja belum sempurna, hal-hal yang menonjol antaranya bahwa konsonan nasal pada akhir suku pertama jarang ditulis." Atja \& Saleh Danasasmita (1981b: 5) state: "penghilangan huruf sengau dalam naskah Sunda kuno merupakan gejala umum. Juga dalam prasasti-prasasti." See also Noorduyn \& Teeuw 2006: 20.
} 
to the phonological structure of the Old Sundanese antecedent: e.g., ${ }_{0}\langle m\rangle p a g$. (Kawa1b.4) is suggested by MdS rempag. We also supply nasals in toponyms, if the base word is identifiable in a dictionary, as in the cases of $r u<\dot{n}>s \partial b$ that we presume to correspond to MdS rungseb, mu<ñ sjul to munjul, cihorñsje to honjé, cimu<ñ $>$ cam to muncang. A particularly evocative example is $s u\langle n\rangle-$ dasambava (Keba1.1v1, 2.1r3, 3.1r1 and 1v1) which all scholars so far have assumed includes the ethnonym Sunda. But certain cases of doubt remain: should we, for instance, edit cibakekem or cibakern் kem (Keba2.1r5-6)? Examples showing loss of velar nasal due to omission of panyecek at word end include $s a$ for $s a\langle\dot{m}\rangle$ (BaTu.3\&5), rahyi for rahyi $\langle\dot{m}\rangle$ (BaTu.4), sam hyi for sam hyi $\dot{m}\rangle$ (BaTu.7), and ditudi for ditudi ìm (Keba1.4).

\subsubsection{Notations of the vowel -o and other uses of panolong}

A recent study by Aditia Gunawan $(2019, \S 1.5)$ shows that in the writing system of pre-Islamic manuscripts from West Java, there is a marker that, in terms of its position, can be identified as the panolong, but which has more than the single function that is recognized for panolong in the Unicode block for Sundanese script, which is to apply the vowel $o$ to a consonant. ${ }^{10}$

First, regarding the representation of the sound /o/, in the manuscripts we find four notations, which are, in descending order of frequency, (1) with lone panolong, (2) with application of pasangan va, (3) with the combination of panéléng and panolong around the basic aksara, (4) with spelling -ve (consonant with pasangan $v$ plus panéléng). ${ }^{11}$ The gebang manuscripts, which are less numerous and generally seem older than the lontar manuscripts, tend to use the third notation, while the latter mostly use the first. ${ }^{12}$ Notation (4) reflects how thoroughly premodern Sundanese scribes had come to confound the two markers that, from a paleographic point of view, must be identified as panolong and pasangan va, evidently because these markers were able with equal adequacy to represent the same sound..$^{13}$ Thus, we do not only encounter free variation in manuscripts between the use of panolong and $-v a$, but even find the fourth notation where the - va clearly takes over the role of the panolong in notation (3). Noorduyn \& Teeuw (2006: 21) have given some examples of this last phenomenon from Bujanga Manik: hoe "cane" is spelled as hvae or

10. See the Unicode table referred to in the caption for Table 1: $1 \mathrm{BA} 7=$ "SUNDANESE VOWEL SIGN PANOLONG $=0 "$.

11. We note here that while our transliteration system is able to distinguish (1) and (3) from (2), it is not able to distinguish (1) from (3).

12. As exception we may mention the manuscript of the Bujanga Manik (Bodleian Ms.Jav.3), whose scribe uses notation (3).

13. Although it seems to be relatively more pronounced in West Javanese manuscripts, this phenomenon is not limited to the Sundanese writing tradition, but also found in Balinese manuscripts for Old and Middle Javanese (prose) texts. See Acri 2017: 56-57. 
even hvee, bogoh "adore" as bogveh or bvegveh. The inscriptions clearly line up with the gebang manuscripts, (3) being by far the most common epigraphic notation of vowel /o/, only one example each being found for notations (1) and (2), both in a single line of a single inscription (Kawa6.6), ${ }^{14}$ and not a single instance of notation (4). The fact that notation (3), which corresponds to the combination of taling with tarung to transcribe /o/ in Balinese and Javanese scripts, has come to be replaced by the notation with a lone panolong (i.e., tarung) in the stage of its development reflected in the lontar manuscripts, is a major structural innovation upon received Indic and Javanese usage in the Sundanese tradition.

Second, besides the panolong's use in transcribing /o/, we also find vestiges of the function commonly observed for the tarung in Old Javanese documents, namely as a marker of vowel length (cf. Acri 2017: 49, 637). A third and most frequent function, which as far as we know is unique to the Sundanese tradition, is its use to mark consonant duplication. We transliterate this marker of lengthening or duplication with a colon. However, in the epigraphic corpus, we find no examples of consonant duplication and only two of vowel lengthening, viz. pura:na (BaTu.1) and ka<ñ ca:na (BaTu.6). It is noteworthy that these two examples are both loanwords from Sanskrit, and that the combination $a$ : is obviously intended to represent Sanskrit $\bar{a}$, even if it means that the scribe misspells Skt. kāñcana as kacāna. This tendency to use panolong in loanwords is also observed in manuscripts, more commonly in gebang but also sometimes in lontar, for example in Perpusnas L 630 for the Siksa Kandan Karasian, in words of Sanskrit origin, such as bhayu: (from Skt. vāyu, 4v2) but also in loanwords from Old Javanese, such as ra:ma (4v1) and Aji: (19v2). The form of the panolong in these three functions is normally identical in the gebang manuscripts (e.g. fig. 2a from Perpusnas L 455), but tends to be differentiated in the lontars: in Perpusnas L 623 for the Bhima Svarga, the marker shown in fig. 2b represents /o/ while that shown in fig. $2 \mathrm{c}$ represents both vowel lengthening and consonant duplication; regarding Bodleian ms.Jav. 3 for the Bujanga Manik, it has been observed to use a marker for consonant duplication (Noorduyn \& Teeuw 2006: 22), and we have found that this takes the shape shown in fig. $2 \mathrm{~d}$, while the same manuscript uses the form shown in fig. 2e for the vowel /o/. ${ }^{15}$

14. The form of lone panolong as /o/ marker in this inscription is quite different from the shape that panolong has when paired with panéléng. See appendix, table 4.

15. We do not know whether the same manuscript contains any instances of the marker shown in fig. $2 \mathrm{~d}$ as vowel lengthener - if it does, then this does not seem to have been noted in Noorduyn \& Teeuw (2006), where the table on p. 434 presents an interpretation of the lengthening/ doubling marker different from ours. 


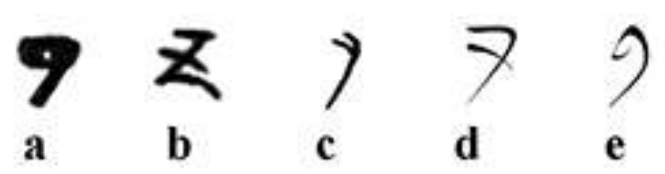

Fig. 2 - Forms of panolong in manuscripts.

\subsection{Grammar and lexicon}

The grammar and lexicon of the Old Sundanese language, as preserved in the available texts, whether in inscriptions or in manuscripts, are generally quite similar to Modern Sundanese. This fact probably explains why there are only very few specific studies of Old Sundanese linguistics. As exceptions, we can mention the work done by Fatimah Djajasudarma et al. (1990), then by Noorduyn \& Teeuw (2006), and very recently by Aditia Gunawan \& Evi Fuji Fauziyah (2021). The reference works we use for Modern Sundanese grammar are Coolsma 1904, Robins 1983, Hardjadibrata 1985, and Müller-Gotama 2001.

Lexical sources for Old Sundanese are minimal. Several dictionaries have been published, although they generally do not distinguish between Old Sundanese and Old Javanese vocabulary attested in texts from the Sundanese manuscript tradition and do not furnish textual references for the sources from which the lexical items are cited (Elis Suryani \& Undang A. Darsa 2003). The only Old Sundanese dictionary that cites the specific textual source for each lemma is the dictionary compiled by Emuch Hermansumantri et al. (1986), but it is based on no more than three texts, namely Carita Parahyanan, San Hyan் Siksa Kandan Karəsian, and Carita Ratu Pakuan. Noorduyn \& Teeuw (2006) have included a glossary based on the three poems edited in their book, Bujanga Manik, Sri Ajñana and The Sons of Rama and Rawana, which forms another useful lexicographical reference. As far as morphology is concerned, we can also rely on Noorduyn \& Teeuw (2006). All morphological features in our epigraphic corpus are also represented in the three Old Sundanese poems on which the two scholars based their grammatical analysis.

Our first step in examining lexical meanings is always to consult the Sundanese-English Dictionary compiled by Radén Rabindranat Hardjadibrata (2003) based on the Soendaas-Nederlands Woordenboek by F. S. Eringa (1984), which is generally very useful to grasp the meaning of Old Sundanese words if they can be matched with a Modern Sundanese counterpart. If this dictionary does not provide a promising avenue for interpretation, we check its consistency with Eringa's and if necessary consult other dictionaries of Modern Sundanese, such as Rigg (1862), Coolsma (1913), Kamus Umum Basa Sunda (1976), and Danadibrata (2006), although the results are often 
disappointing. For more archaic words or words whose Modern Sundanese meanings are not suitable in the Old Sundanese context, we try to assemble any and all occurrences in the corpus of Old Sundanese manuscripts and extrapolate the premodern meaning(s) from the contexts. The translations provided by the editors of these texts are sometimes useful, but most of the time we find that new interpretations are required, based on more rigorous philological analysis. It also happens that the Old Sundanese terms can only be understood by comparing them with their counterparts in Old Javanese or even in Sanskrit.

\subsubsection{The definite article na and the sentence particle ma}

These two morphemes require special discussion, because both are of considerable significance in interpreting texts and our predecessors have tended not to be aware of their respective functions.

First, regarding $n a$, the analysis offered by Noorduyn \& Teeuw (2006: 53-60) is very useful for interpreting phrases containing this morpheme, which can be either an enclitic pronominal suffix, in which case we shall edit it attached to the preceding word (cf. Old Malay -ña, Old Javanese -nya), or an independent word. In the second function, $n a$ can be considered as a definite article (cf. Old Javanese $\dot{n}$ ), always placed before the noun to which it applies (which may be a common noun, a proper name, or a toponym). Eringa (1984, s.v. na 5), followed by Hardjadibrata (2003), records $n a$ in this function in Modern Sundanese. Let us consider the phrase ya nu ñusuk na pakvan (BaTu.4). All predecessors have, by their non-insertion of a space between ñusuk and na, implied that $n a$ is a pronominal clitic, but it seems more convincing to take it as the definite article in its use before toponyms (cf. BM, lines 60, 750). In the phrase mahayu na kadatuAn (Kawa1a.5), Friederich, Holle, and Pleyte considered na to be a suffix, while subsequent scholars have interpreted it as an article. However, we think that all occurrences of $n a$ in the entire inscription should be interpreted as articles, not suffixes. Thus, in the phrase mahayu na kadatuAn, na applies to the noun after it and comes after the transitive verb mahayu, so the meaning is "beautifies the palace." And a few lines further, in pake na gave rahhayu (Kawa1a.8), where all predecessors have interpreted $n a$ as a suffix, and thus edited pakena, we rather assume that $n a$ applies to the noun gave rahayu while the base pake serves as an imperative. The last occurrence, in di na (Kawa1a.10), is problematic inasmuch as the word dina is recognized as a preposition in Modern Sundanese. However, as Noorduyn (1976) suggested in his reading of this inscription, and as suggested again by Noorduyn \& Teeuw (2006: 56), these two syllables can be considered separate words, viz. the preposition followed by the article applying to the following noun.

The second morpheme, ma (cf. Modern Sundanese mah), has been analyzed in a recent article by Aditia Gunawan \& Evi Fuji Fauziyah (2021). 
This particle is found especially in nominal sentences and conditional clauses. In the first case, $m a$ serves as a copula, connecting the subject and predicate. In both cases, $m a$ has a function as a topic marker. An example of a problem of interpretation which involves both $m a$ and $n a$ is found in Keba2.1r2-3, in the phrase $n u$ dipitzkətan. ma na lomah devasasana. All predecessors have read one word, mana, which Boechari and Hasan Djafar suggested to require emendation to nana (so dipitzkatannana). However, in this phrase $m a$ has the function of connecting the subject nu dipitzkstan "that which is made the object of decree" and predicate na lomah devasasana "the land of divine ordinance." Another interesting case involving $m a$ and $n a$ is found in the phrase Aya ma nu pa〈n〉dori pake na gave rahhayu pakən. həbəl. jaya di na buAna (Kawa1a.8-10). In this sentence, the particle ma marks its clause as conditional: the protasis is "if there is" (aya ma) a successor of the King mentioned in the inscription. This hypothetical successor receives an order, marked by imperative verb pake, to perform an action, marked by article $n a$ as a definitive noun modifying gave rahayu "good works."

\subsubsection{Uses of preposition di}

The uses of $d i$ (also spelt $d i$ ) in Old Sundanese have never been discussed so far. In the published translations of OS texts, the preposition di is often treated as though its range of meanings were exactly the same as that of $d i$ "in, at" in MdS (cf. Malay di). In our experience, this preposition has a broader usage in OS, comparable to the use of i/ri/iri in OJ (Zoetmulder 1950: 137-141). Like i/ri/iri in OJ, OS di can also mean 'to, toward," as seen in Keba3.1r1 Ini pitakat(·) nu (s)eba di pajajaran. "this is the decree of the one who renders service to Pajajaran" and Keba2.1v4-5 kenaIm heman, di viku "because I have affection for the hermits," but also in SKK.2 anak bakti di bapa, eve bakti di laki "children are devoted to [their] father, the woman is devoted to [her] husband." An important but often disregarded feature is that OS $d i$, like $r i$ in OJ, can also mark the direct object. We do not find any example of this category in the epigraphic corpus, so offer an example taken from manuscripts: BM.328-330 varuh di na asi tantu, lapat di tata pustaka, varuh di darma pitutur "knows the content of the scriptures, is conversant with the arrangement of the books, knows the law and the admonitions." Finally, di can be used to indicate that the following noun is a toponym, and in such cases loses any prepositional value. ${ }^{16}$ Our first example involves $d i$ placed before a toponym within a transitive construction, obscuring the difference between marking of object and of toponym: mantasin di cihalivun "I crossed the river Cihaliwung" (BM.684, passim with verb mantas). In the

16. This usage, common in OJ, has also been observed in Old Malay. See Griffiths 2020b: 241 n. 79. Tom Hoogervorst points out to us that Literary Javanese ing works the same, e.g. nagara ing Surakarta "the land Surakarta," but nagara ing Éropah "a country in Europe." 
epigraphic corpus we find two examples probably belonging to the category of toponym marking: Keba1.1v1 dayzhan di jayagiri, dəm dayzhan di su<n>dasambava "inhabitants of Jayagiri, and inhabitants of Sundasembawa," and Keba2.1r2-3 lomah devasasana, di su<n>dasəmbava "the land of the divine ordinance, [namely] Sundasembawa."

\section{The Inscriptions}

\subsection{The Batutulis at Bogor}

According to De Haan (1910-1912, vol. II: 364-354, §85 n. 3), the first efforts toward a scientific study of the Batutulis are reflected in a letter from C. F. Reimer to Nicolaus Engelhard dated April 8, 1794. It mentions, among other things, that Reimer asked the president of the Bataviaasch Genootschap for assistance in collecting publications needed for his investigation of the inscription. The first published decipherment is that by Friederich (1853: 442468), who read the inscription through an eye-copy by E. Netscher included in the article. Friederich's interpretation was obviously the work of a pioneer. Later, Holle $(1869,1882 \mathrm{a}, 1882 \mathrm{~b})$ produced a series of articles dealing specifically with this inscription, improving Friederich's readings in many ways. Holle's work represents a methodological leap because he supported his readings by comparison with similar sources such as the Kebantenan plates and lontar manuscripts that were just becoming known in his day. Holle makes use of one of the famous archaeological photographs produced by Isidore van Kinsbergen. ${ }^{17}$ This photo was more reliable than Netscher's facsimile, although Holle acknowledged that the stone having been painted white may have entailed an unfaithful representation of some characters. Pleyte then offered a new reading in 1911, especially emphasizing a different interpretation of the numeral for the hundreds in the chronogram. Hoesein Djajadiningrat (1913) discussed the chronogram in connection with the fall of Pakuan at the hands of Banten. Poerbatjaraka (1919-1921) presented a new reading and interpretation of the chronogram. Noorduyn (1959) discussed the inscription but without proposing a new reading. Saleh Danasasmita $(1973,1975 b, 2006)$ devoted two articles to the study of this inscription, discussing the problems of interpretation in the historical context of early Sunda. The most recent reading was published by Hasan Djafar (2011). It is only from this last edition that we record variants in our apparatus below. Our reading is based on direct inspection of the stone in October 2010, and subsequent study of the estampage made on that occasion, which has since entered the collection of the EFEO in Paris. ${ }^{18}$

17. Theuns-de Boer \& Asser 2005: 226-227. The photo in question is no. 15. It is available online through permalink http://hdl.handle.net/1887.1/item:87820.

18. Among other visual documentation that is consultable, we refer to the photo taken by 


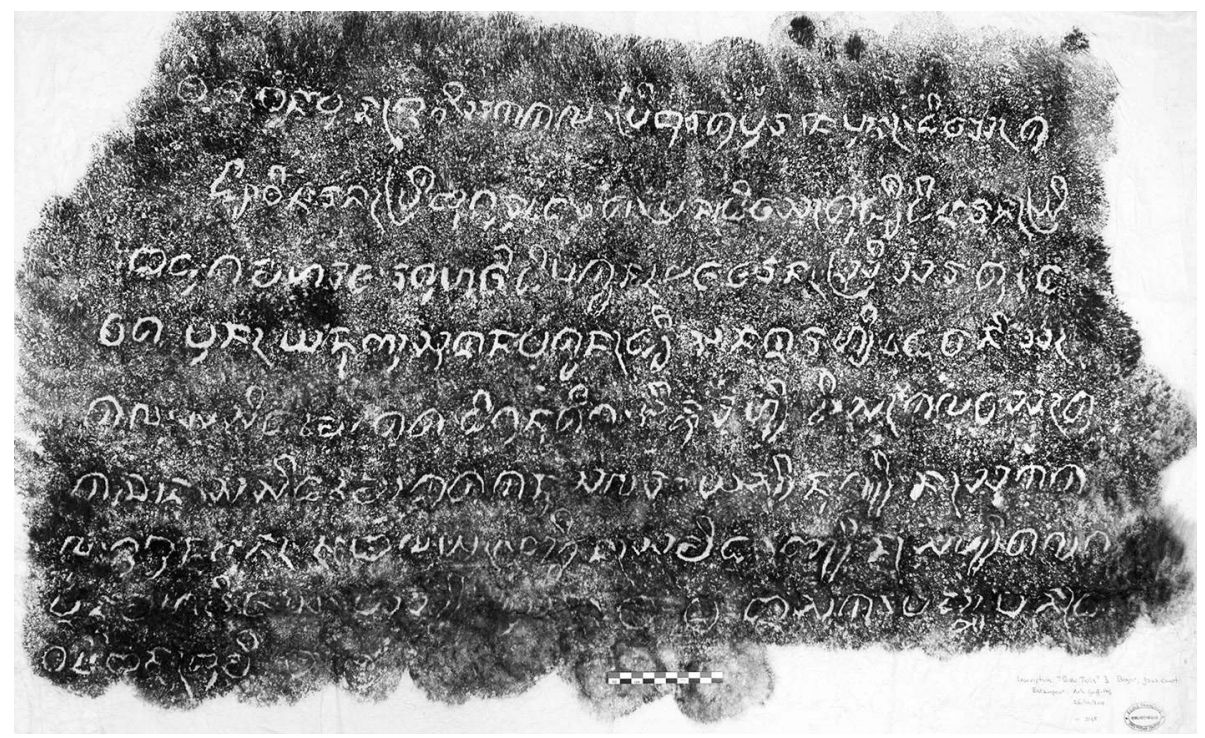

Fig. 3 - The Batutulis inscription (estampage EFEO n. 2148).

\subsubsection{Palaeography}

Generally, the form of aksaras on the Batutulis stone is very similar to what we will see in the Kebantenan plates. For example, the vowel $o$ is written with symmetrical pairing of panéléng and panolong. Another prominent characteristic is the form of $k$. where the pamaéh takes the shape of a stroke below, as shown in fig. 4a. This feature is quite common in manuscripts, irrespective of whether the script type is Old Sundanese or Old Western Javanese quadratic. Another feature which is important to notice is the way the scribe represents the independent vowel a by adding pamepet to aksara A (fig. 4b), a combination we transliterate as $q \partial$. Previous editors read it as $I$. Indeed, the difference in the form of panghulu and pamepet in this inscription is not very clear, but we see a short line that juts to the lower right in the middle of the panghulu. Moreover, the combination of the independent vowel $A$ with the vocalization $i$ would be unusual. What is more common is that the independent vowel $i$ is represented by a distinct glyph containing the glyph for $b a$ with a slanting stroke below it (fig. 4c). However, the form of qa with independent vowel comprising $A$ and pamepet is common in the OS writing system in manuscripts (see figs. 5 and 6 ). Finally, we point out that the scribe uses a character that seems palaeographically to be retroflex $d$, in order to transcribe what is generally written with a sign that palaeographically represents dental $d$. Since there is no phonological distinction between $d$ and $d$ in any form of

Isidore van Kinsbergen; the plate in Pleyte 1911, facing p. 160; the plate in Hasan Djafar 2011. 
Sundanese, it is understandable that Sundanese scribes familiar with the full range of characters available in the Indic script types that were traditionally used for transcribing Old Javanese texts, and this includes the Old Javanese manuscripts produced in ancient West Java, could have chosen the one or the other of the two Indic $d$-s. For palaeographic reasons, we transliterate as $d .{ }^{19}$

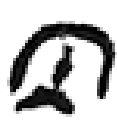

a

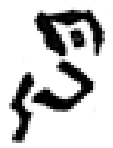

b

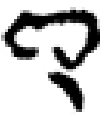

c

Fig. 4 - Palaeographic features of the Batutulis.

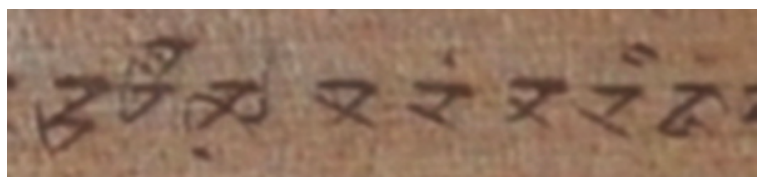

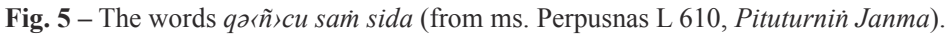

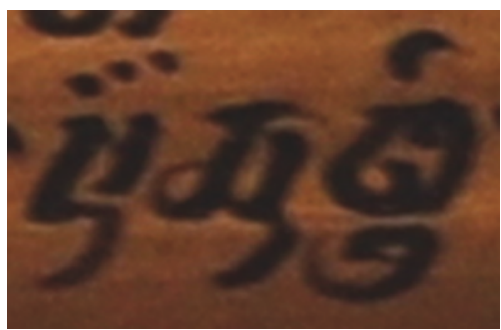

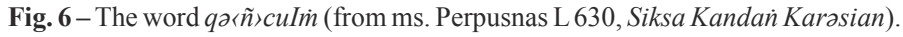

\subsubsection{Text and apparatus}

(1) $\varnothing \varnothing$ vam((n) a`m`(p)un· I(n)i sakakala, pr(ə)bu ratu pura:na pun', divas ·tu

(2) ḍi, vinaran · prəbu guru ḍe(va)ta $\mathrm{p}(\mathrm{ra}) \mathrm{n} \cdot$ ḍivas tu ḍyə ḍinaran· sri

(3) baduga maharaja, ratu ha(j)i di pakvan· pajajaran· sri sa〈m» ratu ḍe-

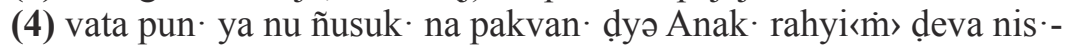

(5) kala, sa〈m〉 sị̣a mok $(\cdot)$ ta ḍi gunum tiga, qəरñ >cu rahyim (n)is $\cdot k a l a ~ v a s \cdot t u$

(6) ka<ñ ca:na, saṁ siḍa mok·ta ka nusa laram, ya syi nu (ñ)yin· sakaka-

(7) la, gugun(un)an·, (na)balay•, ñyin· samiḍa, ñyin· sam hyi<m〉 talaga [va-]

(8) Rna mahavijaya, ya syi pun',, ØØ I saka, pañca pan·̣̣a-

(9) va $\dot{\mathrm{n}}($ ()) $\mathrm{m}$ ๖ban· bumi $\varnothing \varnothing$

19. See Holle 1882c, table p. 4, section B, columns 38-44; van der Molen 1983: 293 (column A). Note that specimens of two different characters, $d a$ and $d a$, have been presented under the label $d a$ in Table 1 in Acri 2017: 49. 
1. The two opening circle-shapes are not clearly visible from a distance but clear on the estampage. - vam( $\dot{n}) a\langle m\rangle(p) u n \cdot \diamond v a \dot{m} n a$ pun. HD. For the shape of $\dot{n} a$, see nabalay in 1. 7. - pura:na $\diamond$ purane HD. There is a vertical stroke between $r$ and $n$, which has been interpreted as panéléng by Pleyte and Hasan Djafar, but we think it is a panolong, for panéléng has a different shape in this inscription. See the panéléngs in mok·ta (11. 5 and 6) and in deva nis·kala (1.4) - they are all different from the shape we see here in line 1. It seems that the marker in line 1 is intended to be the same as the panolong we have identified in kaca:na (1. 5). There is a horizontal stroke on top, but it could be accidental. - 2. dyi, vinaran $\diamond$ diya vinaran $\mathrm{HD}$, with emendation of the second word to dinaran. We accept the emendation and add that $d y i$ needs to be emended to $d y$, the word we also find further on in this line and in 1. 4. $p(r a) n \cdot \diamond$ prana HD. This reading seems impossible to us, for there is unmistakably a sign between the $n$ and the following $d i$, and this sign can only be pamaéh or punctuation. Since the word pran (even if interpreted as paran) does not seem to exist in Sundanese, we propose to emend this to pun', as in lines 1 and 4. - 4. nusuk na $\diamond \tilde{n} u$ suk.na HD. See $\$ 3.2 .1$. — rahyi $\dot{m}\rangle \diamond$ rahiyam HD. We do not see the panyecek.

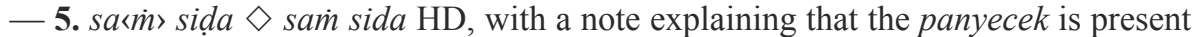
although hard to read. We are inclined to assume that it is absent. Cf. the cases of sa ratu and rahyi for sam ratu and rahyim (= rahiyam) above. - mok(·)ta $\mathrm{HD} \diamond$ We cannot clearly see the bottom stroke expected as pamaéh, but there is a trace of a small stroke to the right and bottom of the aksara $k$. - gunum $\diamond$ guna HD. There can be no doubt about reading with panyuku and panyecek. See the toponym Gunun Tiga in the CP as

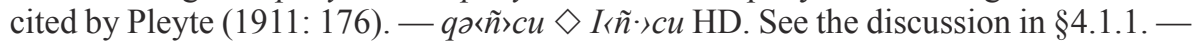
(n)is.kala $\diamond$ nis kala HD. The first consonant is very hard to read as $n$, but that is what it must be. - 6. ka<ñ>ca:na $\diamond k a<\tilde{n}>c a n a$ HD. The vertical stroke after $c a$ is a panolong as vowel-lengthener (see §3.1.7). - 7. (ía)balay. HD $\diamond$ The first aksara is unclear. If we are to follow HD who reads nabalay, then this means that at the beginning of line 1 , we also need to read $\dot{n} a$. Another possibility would be to read (A)balay. Whether we read it as $\dot{n} a$ or $A$, the aksara seems slightly deviant from the other instances of the same aksaras in this inscription. - 7-8. talaga [va]Rna HD $\diamond$ Cf. Pleyte 1911: 172, citation from FCP.6a: ti san hyan் talaga varna miñak hanət sago〈m〉bon் uyah salave kəlek lilitan salave təktək ... "From Talaga Warna: essential oil one gombong, salt 25 kəlek, waist band 25 təktək ..."; cf. also BM 1352-1355, a passage which locates Talaga Warna somewhere around Bukit Ageung (presumably the ancient name of present-day Gunung Gede in Bogor):

sadatan் ka bukit Agən, eta hulu Cihalivun, kabuyutan ti Pakuan, san hian Talaga Varna.
When I arrived to the Mount Ageung, that is the upstream of Cihaliwung, sacred place of Pakuan, the holy Talaga Warna.

\subsubsection{Translation and commentary}

$\mathrm{Om}$, pardon [any errors]. This is the memorial of his majesty the former king, inaugurated here with the name Prabu Guru Déwata, (and also) inaugurated here with the name Sri Baduga Maharaja, king of kings in Pakwan Pajajaran, 
Sri Sang Ratu Déwata. He is the one who demarcated Pakwan here, (being) the child of Rahyang Dewa Niskala, the one who vanished at Gunung Tiga; grandchild of Rahyang Niskala Wastu Kancana, the one who vanished to Nusa Larang. He, that one, produced the commemoration monument, artificial hill, cladded [it] with stone; he produced the ritual ground (samida); he produced the holy Color Lake. Greatly victorious was he! In the year: "the five Pandawas guard the earth" (i.e. in 1455 Śaka).

The contents of the inscription allude to the nature of the site on which it was placed, namely a terrace of the type known as punden berundak, not only in West Java but also in Central and East Java, ${ }^{20}$ whose features were still clearly recognizable to a visitor in 1770. See fig. 7.

1. $\operatorname{vam}(\dot{n}) a\langle m>(p) u n \cdot \diamond$ We interpret this problematic sequence as two words, vamin as an equivalent of $o \dot{m}$ (cf. $\$ 3.1 .7$, although the cases of $-o /-v a$ are there always postconsonantal), the usual invocation at the beginning of texts (seen also at the start of Keba1), followed by ampun "pardon, forgiveness, remission" (Hardjadibarata 2003, s.v. ampun; cf. Malay and OJ "id"). We have not found the word ampun in any other OS texts, but it is found in Carita Pantun Lutung Kasarung (Ajip Rosidi 1973: 49): ampun-ampun sadumuhun (i.e. sang rumuhun), sabeunang-beunang kujang potong "I beg your pardon, $\mathrm{O}$ ancestors, for all the results [achieved merely] with a broken machete (kujang)."

An almost certainly related word that is more commonly used at the beginning of a sentence is pun, as we find in Keba2.1 and Keba4.1. In the manuscript corpus, we find this pun used in a variety of manners. A first example comes from the opening verses of PJ.5-8: pun kami sadu, nitiskan para san hyain, ti luhur satunitun rambut, $t i$ handap sausap dampal "Pun, please allow me to send down the gods, from above as far as the tip of the hair, from below as far as the tip of the foot"; a second comes from the beginning of a mantra in VL.4: ajina, on paksama guru pun, pasaduan kami di na linga si jaja "Its mantra is: 'On, I beg the Guru's pardon, I ask permission to the linga called Jaja".." But it occurs most commonly in dialog, as in BM.445-447: santabe namasivaya, pun kami titahan taan [ti kadatuan], taan uran ajun laran "I beg your pardon! Homage to Siwa! I am instructed by the Lady [from the palace], our Lady Ajung Larang." Noorduyn \& Teeuw tend not to translate this word, except if it occurs in the more extensive form samapun, in which the element sama can be explained as a borrowing, through OJ, of Skt. kșama "patience, forbearance, forgiveness." The word santabe in the previous example is derived from the same Skt. base (see OJED, s.v. sañtabya and kșāntawya). An example of samapun occurs in BM.959: samapun mahapandita, kami nema panividian "My respects, wise man, I accept your gift."

20. On punden berundak sites, which form a kind of link between Indianized culture and megalithic tradition, see Schnitger 1939-1942, Haris Sukendar 1985, Agustijanto Indrajaya \& Degroot 2012. 
In the epigraphic corpus, however, pun appears more often at the end of a sentence. See, e.g., Keba1.1-2: nihan' sakakala rahyam niskala vas'tu kañcana pun. "This is the record of Niskala Wastu Kancana pun." In this usage, one might be inclined to speculate that pun is an abbreviation of sampun "finished, already," as attested in TB.38v4: sampun ñion bəran pətin, nagavay trəna, taru, lata, guluma "[Darmajati] has created the day and night, producing grass, trees, creeping plants, shrubs." This idea might then be felt to find confirmation in the colophon of the PJ manuscript: pun tzlas sinurat, rin vulan kalima pun "pun The writing was finished in the fifth month pun" (cf. OJ sampun "completed, finished; already; after," OJED, s.v. sampun, also pun II). But the word is not used in this meaning in MdS where sampun or sapun means "pardon." We are rather inclined to attribute the same function to both initial and final pun, namely that of lending a ceremonial or polite nuance to the sentence. This nuance seems to survive in its use in MdS, as explained by Coolsma (1904, $\S 165)$ : “[pun] serves the speaker or writer merely to give expression to his humility or politeness". Coolsma's examples show how pun was used in his time, by people speaking or exchanging letters in a respectful manner, using the appropriate lemes register. Cf. also the use of pun in OJ as "a personal demonstrative particle and personal pronoun for the third person, used of so. in a position lower relative to another (usually the addressed)" (OJED, s.v. pun), and the use of pun as a formative element in pronominal and deictic elements of the krama register in Modern Javanese (-ipun, dipun-, punika). In the light of this understanding, we will not translate pun whenever it occurs below. But here, at the beginning of this first inscription, we consider that the formula vain (i.e., on) ampun expresses a meaning analogous to that of on avighnam astu at the start of Keba1. Cf. also the opening of RR.1 on karana santabean.

1. sakakala $\diamond$ Apart from this inscription, the word sasakala also occurs in Keba1.1 and LiWa.2. There is no doubt that it is from the Sanskrit śakakāla which literally means "Śaka-era" but practically comes to mean "chronogram." 21 This definition is suitable if its occurrence coincides with a dating element, as is the case of the Linggawangi inscription. However, this sense is not suitable in Kebantenan 1, where it occurs to designate the decree of a deceased king and we translate it as a "record." Regarding transmitted OS texts, we should especially mention the Bujanga Manik, which includes numerous occurrences of sakakala. On several occasions, the protagonist visits holy places, recalling them as the sakakalas of certain gods or saints: Mount Caru as sakakala of Lord Cupak (BM.695-696), Jalatunda as sakakala of Silih Wangi (BM.731-732), Mount Marapi as sakakala of Darmadéwa (BM.774775). Noorduyn (1982: 421) interprets this word as meaning "the place preserving the memory of." In his edition of this text, the phrase sacunduk ka Jalatunda, sakakala Silih Waini is translated "and arrived at Jalatunda, which keeps the memory of Silih Wangi" (BM.731-732). Thus, the second meaning of this word would be "place of commemoration, memorial." In the episode where Bujangga Manik arrives at Mount Sembung (BM.1080-1087), he narrates how he builds a shrine by erecting a linga

21. See Damais (1958: $51, \S 106)$ for a discussion of śakakāla in this sense. 
(nañjarkən linga), creating a statue (ñiyan haraca) as well as a sakakala (ñiyan sakakala). Here it thus seems that the meaning of sakakala is one grade more concrete, and can be translated, following Noorduyn \& Teeuw (2006), as "monument."

In the Batutulis inscription, the term is mentioned twice, specifically at the beginning part as a statement that the text is a sakakala (line 1), and as one of the king's works (line 6-7). In the latter context, Noorduyn (1959) interprets sakakala as meaning "monument," which is suitable because it appears side by side with other concrete works such as an artificial hill (gugununan), and its cladding with stones (íabalay). However, even here it seems to have the connotation of something related to memory. And so we make our own Poerbatjaraka's interpretation (1919-1921) of the word sakakala in Batutulis, followed by Bosch (1941) for the Old Malay Kebonkopi inscription, as "memorial" ("gedenkstuk"). Further epigraphic occurrences of śakakāla in contexts that support a sense "memorial" - although in all these cases, "chronogram" is an equally fitting or sometimes even the more suitable translation can be found in the Sanskrit inscription of Wurare ("Joko Dolog," from Mojokerto, East Java), dated 1289 CE (Poerbatjaraka 1922: 432), and also in 14th/15th-century Old Javanese inscriptions from hermitage sites (studied in Schoettel \& Griffiths, forthcoming), among which one from Gunung Nyamil, Blitar (1328 CE) ${ }^{22}$ and one from Candi Sukuh, Gunung Lawu, Central Java $(1457 \mathrm{CE}){ }^{23}$

1. pura:na $\diamond$ This must be a loanword from Sanskrit purāna "old." Several OS texts contain the expression purana vindu, sometimes in close contextual connection with the verb divastu. E.g. FCP.3v: kenana urut maharaja trarusbava nahanan sabijil ti na purana vindu "because [it is] where the great king Trarusbawa lived, after [he] appeared from the primordial globule"; further occurrences can be found in SC $17 \mathrm{v}$ and SD.48. Apparently the expression means "of old, in former times."

2. divastu $\diamond$ Cf. RR.681 divastu dijion ratu "inaugurated and made kings" (Noorduyn \& Teeuw 2006: 194, 427).

2. $d y \partial \diamond$ All predecessors have interpreted this word as though it were a $3 \mathrm{~s}$ pronoun (like dia in Malay) but actually the word means "here." In this inscription (as in $\mathrm{HuDa}$ ), only the pronoun siya is used. We do not find dyi (diya) as 3 s pronoun in any OS text. In MdS dia is a dialectal pronoun of the 2nd person (particularly in Banten), besides diana as $3 \mathrm{~s}$ pronoun.

4. $\tilde{n} u s u k \diamond$ This verb has for a long time been interpreted as expressing the foundation of the kingdom. Indeed, Pleyte (1911: 160) translated stichtte, which is Dutch for "founded"; Poerbatjaraka (1919-1921: 389) used the same verb, but in the present

22. // sakakalan(ira) ra kaki (sa)ca (s)un(y)a hatapa racut gunu(m ña)mil // sunyamarga pakșani $(\dot{m}) v o(\dot{m})$ "The memorial/chronogram of the venerable elder Saca sunya who performed (liberating) penance on Gunung Nyamil: void-path-wings-man."

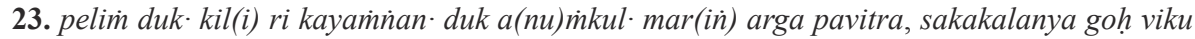
hanahut butut', 1379, 'Commemoration of the time when the nun was at the sacred place (hermitage?) [and] when she paid homage to Mount Pavitra. Its chronogram is "Cow as Ascetic biting [its] tail". 1379.' 
tense (sticht); the entire discussion in Hoesein Djajadiningrat (1913: 139-144) is based on the assumption that the inscription records the date of foundation of Pakuan Pajajaran. Pleyte (1914a) dismissed the text which is known nowadays under the title Amanat Galungun as a "Pseudo-Pajajaran Chronicle" for no other reason than that the figure said to ñusuk Pakuan is another than the king who ñusuk Pakuan Pajajaran in our context. It is only in the work of Saleh Danasasmita (1973) that we see these assumptions starting to be questioned. We translate "demarcated" and limit ourselves to citing two occurences in AG3r: jaga is ss di carek nu kolot, nalalokən agama nu ñusuk na galungun், marapan jaya pran் jadyan tahun "One day, [you] should pay attention to the prohibition of the elders by ignoring the sacred doctrine of the one who demarcated Galunggung, in order to gain victory in battle and the success of harvest." Cf. Kawa1 for the use of the nearly synonymous verb marigi "to dig a moat, a trench." In MdS, Rigg (1862, s.v.) notes that nyusuk means "to cut a canal, to cut a trench in the earth." This seems to be in accordance with Carita Pantun Demung Kalagan, which implies the meaning "to demarcate":

basa nyusuk ti pakuan
sawétaneun gunung cisalak
sakaléreun gunung gedé
basa nyusuk ti pakuan
basa ngabedah di kuta pajajaran

ku prebu susuk tunggal nu nyusuk kali cihaliwung téa

\begin{abstract}
When [he] demarcated Pakuan from the eastern part of Mount Cisalak from the northern part of Mount Gedé when he demarcated Pakuan when he established the fort of Pajajaran [it is done] by King Susuk Tunggal who demarcated the river Cihaliwung
\end{abstract}

In OJ epigraphic texts, the verb susuk typically occurs in constructions such as manusuk sima, literally meaning "to demarcate a sima," which clearly imply the foundation of a religious freehold. Cf. also Old Malay Panai inscription ( $c a$ 11th/12th c., Padang Lawas, North Sumatra) which contains the phrase mañusuk bumi (Griffiths 2014a: 235). In our opinion, therefore, the OS word ñusuk can also imply the meaning "to open up, to found." The apparent contradiction between Batutulis and Amanat Galungun about who ñusuk Pakuan should not be resolved by regarding one right and the other wrong, but can be seen as a reflecting the different concerns of their respective authors (see our discussion in §5). We may conclude this comment by pointing out that that the chronogram in this inscription, generally assumed by previous scholarship as marking the date of the founding of Pakuan, most probably does not furnish the date of the event intended by ñusuk at all, nor that of other works of the king, but rather that of the production of the memorial (sakakala) inscription itself. See our discussion in §4.1.4. 6. nusa laram $\diamond$ This place is mentioned in CP. 21 b: aya na səvə prabu vani inaranna iñana prabu niskala vastu kañcana nu surup di nusa laran் "There is a son of the king called Prabu Wangi, he is King Niskala Wastu Kancana, who has vanished at Nusa Larang."

7. nabalay (or Abalay) $\diamond$ Rigg (1862) describes balay as "an ancient and sacred spot, for making offerings and prayers," adding that "they are frequently found on mountain tops throughout the country, and are often still held in some degree of awe by the natives." According to Hardjadibrata (2003), balay means "join together 
(natural) stone (as paving around the house, as reinforcement of the roadway, as delimitation around a graveyard, as a path)" while ngabalay means "put such paving etc. somewhere." BM.1409-1414 depicts the practice of dibalay with some detail:

ku nain gas dibabakan, dibalay diundak-undak, dibalay sakulilinna, ti handap ku munkkal datar, sər man்gu் ku mun்kal bənər, ti luhur ku batu putih.
It was set up as place by me, it was cladded with stone, arranged in terraces, paved all around, from below with flat rock, whirling upwards with "true/straight" rock, from the top with white stone.

In another part of the same text, the meaning of dibalay denotes embellishment with jewels (dibalay ku pràramata) in a garden (BM.1582), or with pearls (dibalay ku muterihara) on a palanquin (BM.1713). In our context, some scholars have interpreted the word as meaning "to harden the earth." But taking Bujangga Manik's description and Rigg's notes into account, it seems more likely that nabalay is related to covering such structures with stone. If we read gugununan Abalay, the meaning will be "an artificial hill with stone cladding." See also fig. 7.

7. samida $\diamond$ The word samida means firewood (Skt. samidh), but we believe that the word is used here as equivalent for pasamidaan, a term designating the place where various acts of religious devotion were carried out, as in SC.1125: dən்n bale pañyəkan, sañgar paiyilan, pahoman n்urun jalan, kalavan pasamidaan, gasan inkus puja ñapu "with the weaving pavilion, the shrine paiyilan, offering places surrounding the road, along with the

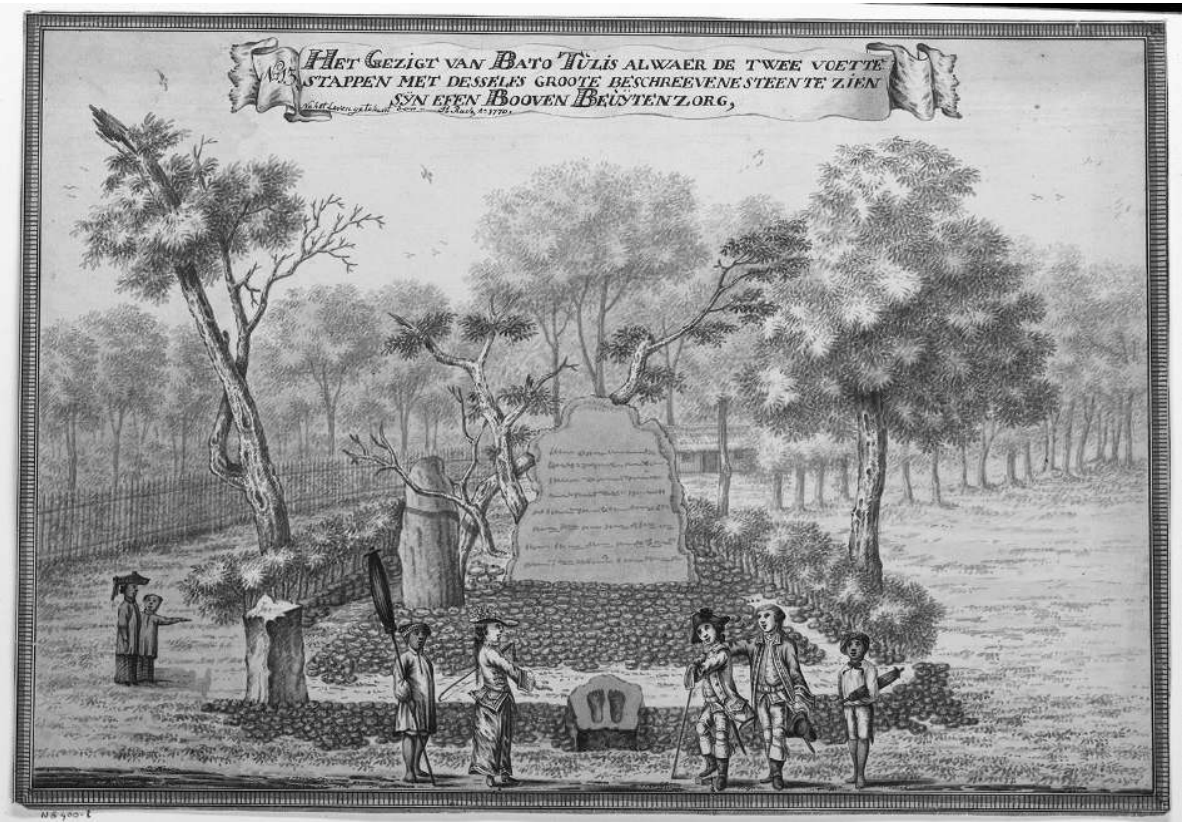

Fig. 7 - Johannes Rach's painting of the Batutulis, 1770 (https://www.rijksmuseum.nl/en/collection/NG-400-I). 
place for firewood (pasamidaan), for burning incense, worshiping, and sweeping." There are instances in MdS where the base word has the same meaning as its derivation with pa--an, e.g., jimat and pajimatan "amulet" (Robins 1983: 116-117).

\subsubsection{Chronogram and Chronological Framework}

The Batutulis is the inscription most abundantly discussed by previous scholars because it is the only one that mentions names of kings along with a date, although the word designating the century number in the chronogram is very controversial both in terms of its reading and in terms of its numerical value. We read the problematic word as $\dot{n} \partial\langle m \succ b a n$. Pleyte read it as $\partial$ ban, which he understood to mean $ə\langle m\rangle b a n$. He was relying on the opinion of Kern, who proposed to Pleyte that the word aban stands for amban and can express the value 4 "because it happens in Indian narratives that rich folks' children have four nurses" (Pleyte 1911: 162). This meant that the Batutulis was dated to 1455 Śaka (1533 CE). Hoesein Djajadiningrat (1913: 143-44) disputed this interpretation and considered that other historical data imposed attributing to the problematic word the value 3 , to obtain the year 1355 Śaka. He did not offer an interpretation of the chronogram as a sentence nor did he take a firm position on the reading amban proposed by Pleyte, but noted that the mention of the five Pandawas makes one think of the 3 panakawans, so that amban might express the same value and meaning. Subsequently, Poerbatjaraka (1919-1921) established the correct reading of the word as $\dot{n}$ ‘m $\rangle$ ban, which he took as a synonym of the Javanese chronogram word nambah, the shared semantic element being the use of two hands, so that he was able to translate the sentence as "the five Pandavas cradle the earth" while assigning to irmban the value 2 , to obtain the date 1255 Śaka.

Saleh Danasasmita (1973: 12-13, 2003: 32) connected the word amban with panakawan = sakawan "companion," assumed that it would have the value 4 that the latter words have in Javanese candrasengkalas (Bratakesawa 1980: 51), and was inclined to consider this the type of chronogram that cannot be translated as a sentence. We are differently inclined, and point out in favor of the reading ṅmban, which Poerbatjaraka translated as "cradle," that the word does not only mean "to carry on both arms or in a carrying-shawl, cradle" but also "to be the guardian of" or "to be the companion of" (OJED, s.v. ěmban).

None of of our predecessors was aware that the word ṅmban actually figures in Balinese chronogram lists collected by H. N. van der Tuuk and Victor Korn - always expressing the value 2. Although these texts date to the late 19th century in their extant forms, it is likely that at least some of the material contained in them was drawn from considerably older sources. ${ }^{24} \mathrm{We}$ have to admit that the interpretation of the word in this value 2 seems more

24. Cf. Hägerdal (2006) on Balinese chronogram lists, with examples of ṅmban (ngemban) on pp. 81, 83, 104,178, 185, 189 and 190. We owe the information on rimban in Balinese sources to Wayan Jarrah Sastrawan. 
intuitive than the value 4 (because "to cradle" implies the presence of two people) and if it is accepted in the Batutulis, it would mean reverting to the date 1255 Śaka proposed by Poerbatjaraka.

In terms of its sequence of rulers, the inscription shows a rather striking agreement with the Carita Parahyanan while the same sequence of three generations of rulers is also reflected in the Kebantenan inscriptions (to which we turn in §4.2). However, assigning to the Batutulis the date of 1255 Śaka would lead to a difference of about two centuries with the chronology implied by the Carita Parahyainan (CP), as inferred by several scholars on the assumption that the composition of the chronicle must be coeval with the Banten sultanate's defeat of Pakuan in $1579 \mathrm{CE} .{ }^{25}$ If this date may be relied upon at least as an approximation of the date of composition of the CP, it is then possible to go back in time following the information on the lengths of reign of the kings of Pakuan recorded in the chronicle, which does not itself use absolute dates. Using this method, we obtain the following chronological sequence from the last ruler of Pakuan down to Niskala Wastu Kancana who is mentioned in the inscription as well as in the $\mathrm{CP} .{ }^{26}$

- Nu Siya Mulya, 12 years
- Nilakéndra, 16 years
- Sang Ratu Saksi, 8 years
- Ratu Déwata, 8 years
- Surawisésa, 14 years

$$
\begin{array}{r}
1567-1579 \\
1551-1567 \\
1543-1551 \\
1535-1543 \\
1521-1535
\end{array}
$$

Then we reach the kings mentioned (though rarely under exactly the same names) in the epigraphic corpus:

25. See Pleyte 1911, Amir Sutaarga 1965, Saleh Danasasmita 1973 \& 1975b, De Graaf \& Pigeaud $1974 \S 6-03$, Ricklefs 2001. As Wayan Jarrah Sastrawan points out to us, the universally cited date of 1579 (= 1501 of the Javanese era) is based solely on the reliability of the chronogram given in the Sajarah Banten, whose oldest dated manuscript dates back only as far as the 1730s (see Titik Pudjiastuti's 2015 edition of four versions of the Sajarah Banten, p. 64 for the two oldest dated manuscripts both dated 1732 CE, and p. 284, stanza XX.17, for the chronogram, apparently corrupt in one of these two manuscripts, viz. Leiden Or 7389, that was used by Titik Pudjiastuti as basis for her edition — and see Hoesein Djajadiningrat 1913: 132 for the reading and interpretation of the chronogram in the manuscripts he consulted). The 1579 date is not implausible, given what is known from other sources of Banten's expansionism in the $1570 \mathrm{~s}$, but it is also not as solid as the secondary literature often suggests. Centennial years like 1500, 1501 and 1503 are also related to the idealised "rise-and-fall" cycle of kratons in the Modern Javanese Tradition (cf. Ricklefs 1999), which makes us wonder how much trust we can put in its accuracy.

26. We follow the chronology reconstructed by Saleh Danasasmita (1973, 1975b, 2003), which is eight years shorter than that of Amir Sutaarga (1965). The latter interpreted sadawidasa as meaning that the reign of $\mathrm{Nu}$ Siya Mulya lasted "twenty" years, while the former interpreted the numeral as meaning "twelve." 
- Ratu Jaya Déwata, 39 years

$1482-1521$

named Guru Déwata, Baduga Maharaja and Ratu Déwata in BaTu; named Baduga Maharaja and Ratu Déwata in Keba; expired at Rancamaya according to CP

- Tohaan of Galuh, 7 years

$1475-1482$

named Rahyang Dewa Niskala in BaTu, Ningrat Kancana in Keba; expired at Gunung Tiga according to both $\mathrm{CP}$ and $\mathrm{BaTu}$

- Niskala Wastu Kancana, 104 (!) years 1371-1475

thus named also in BaTu and Keba, expired at Nusa Larang according to both $\mathrm{CP}$ and $\mathrm{BaTu}$

Taking into account the significant correspondences between the CP data on the names of kings and their places of decease (or enshrinement), on the one hand, and those of the inscriptions, on the other, it seems necessary also to give some credence to the chronicle's information on lengths of reign, notwithstanding the fact that the reign of 104 years ascribed by its author to the king furthest removed from him in time is very suspect.

Based on this chronology, it is difficult to accept the interpretation of the chronogram of the Batutulis as expressing the year 1255 Śaka. The only interpretation that would fit the absolute chronology above is that of Pleyte and Saleh Danasasmita, viz. 1455 Śaka, implying that the word ṅmban could express the value 4, at least for the author of the inscription. This would place the inscription in 1533/1534 CE, or about twelve years after Sri Baduga Maharaja expired, when he would still have been in living memory as a former (purana) king. This is the conclusion we hesitantly maintain in our translation above, despite the very significant countervidence on the value of the chronogram word namban in Balinese sources. As we will outline further on (§5), we have the impression that the inscription fits well in what is known about the historical context of the first half of the 16th century CE. Most of the other epigraphic and manuscript material in Old Sundanese is indeed dated or dateable with some confidence to the 15th-16th-century range.

Unless and until new sources emerge to confirm or refute the conclusion reached above, we must of course remain open to other possibilities. One of these would be to reject the Carita Parahyanan altogether as a reliable source for questions of absolute chronology, and to move the entire chronology outlined above back in time by about two centuries. But this would mean moving the inscription to a completely different historical context, which seems implausible to us. Another possibility would be to imagine that the inscription was created at least some decades after the decease of Sri Baduga Maharaja in the early 16th century $\mathrm{CE}$ but that the author of the inscription did intend 1255 Śaka, not as an authentic historical date but because he wished to make his contemporaries believe that this former king had lived about two centuries further in the past than he actually had. Although this last interpretation is highly speculative, it is the only one we see that allows us to 
work with the expected value 2 for ṅmban while also allowing us to keep lending some credence to the information contained in the Carita Parahyanan and to retain the Batutulis as a product of the 16th century.

\subsection{The Metal Plates from Kebantenan}

This item consists of five copper plates found in desa Kebantenan, kabupaten Bekasi, West Java. In the center of each plate, there is a small hole clearly applied prior to engraving the text, in the manner also seen in palmleaf manuscripts, indicating that the plates form a set that was intended to be bound together with string. When found, they were used as objects of worship, hanging on a string in a small house belonging to a farmer $(N B G 5,1867$ : 38). It was Raden Saleh who first informed the Bataviaasch Genootschap of the existence of these inscribed plates. Although the farmer did not at that time allow the society to purchase them, they were offered to the Bataviaasch Genootschap two years later by the assistent-resident of Meester-Cornelis (present Jatinegara) to whom they had been shown by another man as though they were proof of ownership of a tract of land called Cipamingkis ( $N B G 8$, 1870: 74 and 80-81). Today, they are still kept in the National Museum, Jakarta, under inventory numbers E. 42 through E. 45.

The inscriptions on these plates were first read by Holle (1867b: 559-567, 1872:367). As a pioneering scholar, Holle deserves appreciation for the relative accuracy of his readings. Pleyte (1911: 163-167; and appendix 2, pp. 198199) gave a new and improved reading of the text, especially the passages concerning taxation, in his lengthy article on the chronology of the kings of Pajajaran based on data from inscriptions and manuscripts. Boechari (19851986: 103-107) published the texts again, ${ }^{27}$ though without any translation or interpretation, and this edition in turn was the main reference used by Hasan Djafar (1991), who offers Indonesian translations for Keba1-4. Since none of

\begin{tabular}{|l|l|l|l|}
\hline Number & Facsimile Pleyte & Rubbing Leiden & Photos \\
\hline 1. MNI E 42 & $\sqrt{ }$ & $\sqrt{ } 29$ & $\sqrt{ }$ \\
\hline 2. MNI E 43 & - & $\sqrt{ }$ & $\sqrt{ }$ \\
\hline 3. MNI E 44 & - & - & $\sqrt{ }$ \\
\hline 4. MNI E 45 & - & - & - \\
\hline
\end{tabular}

Table 2 -Visual documentation used for editing the Kebantenan plates.

27. Boechari suggests about these plates that "Nampaknya lempengan ini bekas piagam lama yang dihapus dan kemudian ditulisi piagam baru" (almost the same words are repeated four times on pp. 103-106). We do not understand what gave Boechari this impression. 
the previous editions totally supersedes its predecessors, we systematically report the readings of all four previous editions in our apparatus. ${ }^{28}$

\subsubsection{Paleography}

There is on the whole great similarity to the script seen in Batutulis, for example in the spelling of vocalization $o$ with symmetrical panéléng/panolong and the exclusive use of $d$ instead of $d$, but some characters are similar to those used in the Kawali group (see Eka Noviana 2020: 116-117). A small difference from Batutulis lies in the use of two manners of writing $k \cdot$ In Kebantenan we find not only the manner used in Batutulis, where the vowel killer is a horizontal line under the aksara $k$, but also the more wide-spread manner, which involves adding a standard pamaéh to the aksara k. However, the aksara $n$ (fig. 8a) is very similar to the one used in the Kawali inscriptions and different from the one seen in Batutulis. We also find one unusual aksara, shown in fig. 8b and interpreted by us as $g h$ in Keba1. ${ }^{29}$ The grapheme $g h$ is different both from $k$ and $g$ in this group of inscriptions; it resembles the sign that expresses $\tilde{n}$ in the Kawali inscriptions, but is different again from $\tilde{n}$ in the present group of plates. It is also different from the shape of $g h$ in Old Western Javanese script (see Acri 2017: 638). Another character that is quite exceptional is the $s ́$ (fig. 8c) that occurs twice, both times in the aksara śri. Previous scholars who dealt with the Kebantenan plates have always transliterated it as $s$, thus conflating this character with $s$ proper (fig. 8d). Finally, one characteristic that is quite prominent is the shape of aksara $E$, which is similar to aksara $l$ but with a panghulu on top. It is unfortunate that when Aditia Gunawan checked the plates at the National Museum, the character in question could not be photographed. However, in his table Holle (1882c: 25, no. 79) has reproduced this aksara $E$ as shown in fig. 8e.

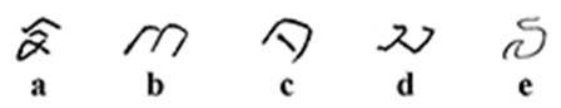

Fig. 8 - Palaeographic features of the Kebantenan inscriptions.

\subsubsection{Kebantenan no. $1=$ MNI E. $42 a$ and $b$}

This was previously edited by Holle (1867b: 563, Plaat II and III) and Pleyte (1911: 163-164), then by Boechari (1985-1986: 103), and most recently by Hasan Djafar (1991: 10). Aditia Gunawan checked the reading in May 2013,

28. We do not know if all three expected rubbings can be found in Leiden, but in the set of photos of the rubbings that is at our disposal, we only find one of plate 2, recto.

29. Holle read it as $g$ in his $1867 \mathrm{~b}$ article, but he later represented it as $g h$ in his famous Tabel van Oud- en Nieuw Indisch Alphabetten (1882c: 7, column no. 79). 


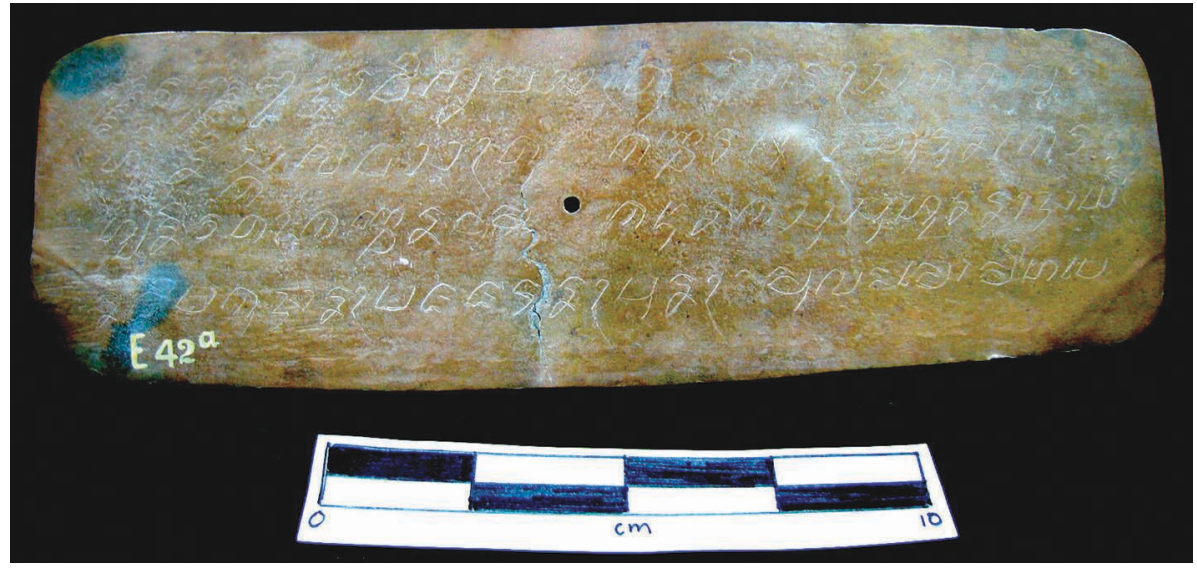

Fig. 9 - Kebantenan no. 1 (MNI E 42 a recto, photo by Terrylia Feisrami).

then reread the text with Arlo Griffiths on the basis of the rubbings from the Kern Institute collection in Leiden, of Pleyte's facsimile, and of photographs kindly shared by Terrylia Feisrami.

This inscription is engraved on two very thin copper plates, measuring $21.5 \times 6.5 \mathrm{~cm}$ each. The first plate has four lines of writing on its two sides; the other one has 3 lines of writing on only one side. The bottom side of the second plate is damaged, but the reading is not disturbed because the part in question does not bear writing.

\subsubsection{Text and apparatus}

\section{Plate 1, recto.}

(1) // Ø // Om் Avighnam as·tu, nihan· sakakala ra-

(2) hyam niskala vas ·tu $\bigcirc$ kañcana pun', turun· ka ra-

(3) hyam nimrat k kañcana, ma $\bigcirc$ kanuni ka susuhunan· Ayə-

(4) na di pakuAn· pajajaran· pun', mulaḥ mo mihape

\section{Plate 1, verso.}

(1) ḍayəhan · di jayagiri, ḍəm ḍayəhan · ḍi su<n>ḍasəmbava,

(2) Aya ma nu nabayuAn · O Iña Ulah ḍek · nahəryanan ·

(3) Iña, ku na ḍasa, cala $\bigcirc$ gara, kapas timbam, pare $\lceil-$

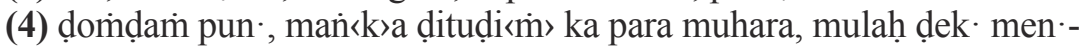

Plate 2 recto.

(1) taAn· Iña beya pun·, kena Iña nu puraḥ ḍibuhaya,

(2) mibuhayakən· na kacari $\bigcirc \operatorname{taAn} \cdot$ pun·, nu pagəh navaka-

(3) n· na devasasan·na $\bigcirc$ pun· $\varnothing, \varnothing$ 
1r1. Avighnam $\diamond$ avignam H P B HD. - 1r4. pakuAn $\cdot$ H B HD $\diamond$ pakvan $\cdot$ P. — 1v1.

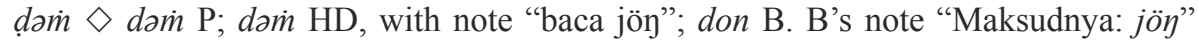
makes clear that his reading is a printing error for $d \ddot{\eta} \eta$. See our comment on this word below (\$4.2.2.2). — su<n〉dasəmbava $\diamond s u<n>d a ~ s ə m b a v a$ H P B HD. -1v3. Iña, H

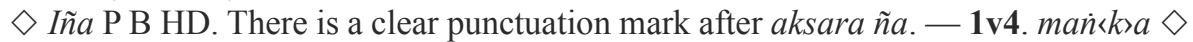
maña $\mathrm{H}$ B HD; manga $\mathrm{P}$. — ditudi $\dot{m}>\mathrm{P} \diamond$ ditudi $\mathrm{B} \mathrm{HD}$. H reads ditudi but emends it to ditu<ñ jaì. - 2r1. beya $\mathrm{H} \mathrm{B} \mathrm{HD} \diamond$ beya $\langle>\mathrm{P}$.

\subsubsection{Translation and commentary}

Om. Let there be no obstacle! As follows was the record (sakakala) of Rahyang Niskala Wastu Kancana, that came down to Rahyang Ningrat Kancana and also to His Highness now [ruling] at Pakuan Pajajaran (i.e., to Sri Baduga Maharaja). Do not omit to take care of the inhabitants of Jayagiri and the inhabitants of Sundasembawa. If there is someone providing them livelihood, don't be eager to disturb him with the dasa, calagara [penalties], cotton timbain, rice paddy dondain [taxes]. Also with regard to the [people from] various river mouths: don't be eager to ask them toll. Because they are the ones who are assigned to be cherished, who cherish the code of conduct, who firmly practice the divine ordinances.

1r1. sakakala $\diamond$ See our comment under BaTu.1 (\$4.1.5).

1r4. mihape $\diamond$ This word means "to take care." See also KUBS s.v. mihapé 2, which cites an expression mihape poé paré "ménta dipangnalingakeun," meaning that the paddy should be watched carefully. HD translates mulah mo mihape "telah menitipkan," while the construction of mulah mo in OS texts implies an imperative "do not fail" (like Indonesian jangan tidak). Cf. SC.33-37: mulah mo rən் svarain, svarain ayəna ini, mulah mo mihape iña, suganin salah tucap, suganin salah səbat "You must not fail to listen to my voice, this voice of mine, now; you must not fail to pay attention to it, for there might well be an error of speaking, there might well be an error of citation."

1v1. dam $\diamond$ This conjunction is common in the OS corpus, but unfamiliar from the point of view of MdS (where the common coordinating conjunction is jeung). While

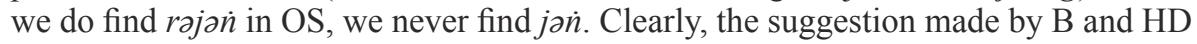
to read ja: $\dot{n}$ was only based on their knowledge of MdS.

1v1. dayzhan $\diamond$ This word is not found in MdS. Cf. the glossary in Noorduyn \& Teeuw (2006, s.v. dayeuhan). It is clear that in OS contexts, this word means "inhabitant" (from dayzh "settlement"), based on the occurrences in RR.224-227 and 1430-1434, BM.25-29. Cf. also SMG.2 and WL.12\&18. Pleyte (1911: 164) assumes the meaning "capital," while Hasan Djafar (1991) leaves the word untranslated.

1v1. $s u<n>$ dasəmbava $\diamond$ We read su<n>dasəmbava as a single word, because it seems to be a Sanskrit-style tatpuruṣa compound, meaning "the origin of Sunda."

1v2. Aya ma $\diamond \mathrm{Cf}$. MdS mah. For the use of $m a$ in OS sentences, see Aditia Gunawan \& Evi Fuji Fauziyah 2021.

1v2. naharyanan $\diamond$ Previous scholars have related this verb form to MdS heureuy "to tease." One occurence of the passive form dihrryanan in KK.2r seems incompatible with 
such a meaning, and rather implies that the verb means "to obstruct, to hinder": tahər hibar dilah siya, kilan் kapindinan mega, kilan் kapindinan bukit, sankkilan dihərianan, hantz kaalan-alanan "then your light is bright, even if it is covered by the clouds, even if it is covered by the mountains, even if it is hindered, it would not be obstructed." We therefore propose to associate the OS forms with MdS heurin. Hardjadibrata (2003, s.v. heurin) notes forms such as ngaheuheurin "make st. overcrowded, take too much space, be in the way," ngaheurinan that has the same meaning as ngaheuheurin, and also kaheurin "st. that stands in the way, obstacle, impediment." Compared with these MdS data, is seems that we have to assume an OS base form horian from which is derived a secondary base through suffix -an, and finally a verb with prefix $\dot{n} a-$, morphologically analogous to nga-heurin-an in MdS but having a meaning, "to obstruct," that is only recorded for other specific forms in MdS.

1v3. dasa calagara $\diamond$ Our predecessors have offered various comments on the interpretation of these two terms that appear to be related to payment of tax or penalties. As Pleyte's did, our analysis starts by comparing SMG.15, which contains relevant information: von papa ma nu bobotoh, ${ }^{30}$ von் kalesa ma na dasa, si manaren ma, calagara, si manarek" ma, na panuran "the gambler is a sinful man, the dasa is a stained man; the calagara is one who manaren; the panuran is one who extracts." This passage suggests that the word dasa can be traced to Skt. dāsa, which means "slave, servant" (also in OJ). Regarding the word calagara, in view of the frequent correspondence of Sundanese /c/ to Javanese /w/ (Nothofer 1975: 301-310), it may be considered the Sundanese equivalent of OJ valagara, a rare word glossed as follows in OJED, s.v.: "prob.: a kind of marriage (sexual intercourse?) which is normally prohibited (with a young girl, wāla?); also: the corresponding contribution (to obtain permission) or penalty." In our view, the term is ultimately derived from Sanskrit balātkāra "employment of force, compulsion, violence; (in law) the detention of the person of a debtor by his creditor to recover his debt" and not or only secondarily connected with vāla "child." The word valagara is attested, to our knowledge, in two OJ inscriptions, ${ }^{32}$ in the still unpublished texts called Śaivaśāsana and Rșiśäsana and in the published Kutāra-Mānava. ${ }^{33}$ Although none of the relevant passages make perfectly clear what the term means, they do reveal that valagara had some connection with a particular way of marriage engagement and was a kind of payment that needed, under normal circumstances, to be made to the government. Occurrences of balattkāra, or derived forms, in OJ Parva texts and in inscriptions from Bali, seem compatible with the

30. Cf. Kawa6 and our commentary on bvatoh.

31. The manuscript has manareka. A scribal error $k a$ for $k$. may easily occur by omission of the pamaéh. We thus read manarek and interpret it as an equivalent of Malay menarik "to extract." See also Nothofer (1975: 230) showing that related languages have /e/ instead of /i/ in the word which is tarik in MdS.

32. The two occurrences are valagarādhi "valagara etc." in the Kaladi inscription (dated to 831 Śaka, but a reissue probably dating to the late Majapahit period - Barrett Jones 1984, App. 4), 8v4, and pabə:ñjat. (v)alaghära "levy on illegitimate children and on valagara" (?) in the Narasinghanagara inscription (13th century — van Naerssen 1941: 46-54, reading corrected by Arlo Griffiths based on a photo of the plate), 14r4-5.

33. The passages from the Śaivaśāsana and Rsisiśāsana (texts currently being edited by Marine Schoettel as part of her doctoral research) are cited in OJED from manuscripts; the KutāraMānava occurrence is in 191.1 (ed. and transl. Jonker 1885: 76 and 142). 
hypothesis that it and valagara are connected terms, their interrelationship being a topic that requires further research. ${ }^{34}$ Returning to the quoted SMG passage, we see calagara associated with a word spelled manarem in the manuscript, which Pleyte (1911: 198-199) as well as Atja \& Saleh Danasasmita (1981c: 59) represented as manarö $\dot{n}$. This error for the vowel led these scholars to consider manaran as derived from the base barən் (MdJ and MdS bareng "together"), thus giving rise to the assumption of a meaning like "collective tax," and contrasting this with dasa as individual tax. Now if we rely on the manuscript, the SMG passages actually reads manaren instead of manaron, but this is hard to accept since there is no such word in OS or MdS. We tentatively propose to read si manarema ma instead of si manaren ma, assuming that the panyecek in the manuscript is accidental and that haplography has occurred. The form manarema can then be derived with prefix $m a N$ - and infix -ar-from the base tema "accept" that we also find elsewhere in OS. See e.g. BM.959 samapun mahapandita, kami nema pañvidian "Pardon, wise man, I accept your gift" and KP.43 katema ku botara indra "was accepted by the God Indra." Thus, si manarema could mean "the ones who accept (each other in marriage)." It would also be possible to obtain more or less the same meaning if we assume the base is tarema, i.e. MdS tarima. ${ }^{35}$ In either case, to obtain the reflexive meaning, one would actually expect to read si patarema ma - but this is even further removed from the transmitted reading, and thus we are forced to admit that the interpretation of the passage remains doubtful. Nevertheless, it seems clear that dasa and calagara in this passage designate types of people liable to pay certain penalties. This is inconsistent with the use of the same terms in two passages of the Siksa Kandan Karzsian. These are, (a) SKK.9: jaga

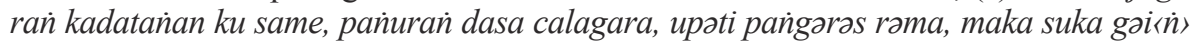
uran், maka rasa kadatañan ku kula-kadan, ku baraya "One day we'll be visited by the same, ${ }^{36}$ collector (pan்uran) of (penalties such as) dasa, calagara, upəti, pangərəs rəma. Then we'll be happy, then we'll feel (like) being visited by relatives, by family members," and (b) SKK.10 də⿱亠凶 maka ilik-ilik di na turutanən, mantri, gusti, kasasa, bayaìkara, nu

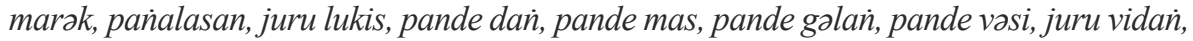
vidu, vayan், kumban, gəndin, tapukan, bañolan, pahuma, pañadap, pañavah, pañapu, belamati, juru moha, barat katiga, pajurit, pañumpit, pamanah, pamran், pan்uran் dasa calagara, rare an்on, pacelenan, pakotokan, palika protələm, sin savatək guna, aya ma nu satiyadiguna di kahulunan, eta keh na turutanən, kena eta navakan tapa di nagara "And then pay attention to the ones who should be followed: officer, noble man (gusti), kasasa, member of the bayangkara corps, confidant (nu marzk), messenger, painter, coppersmith, goldsmith, bracelet smith, blacksmith, architect (? juru vidan), actor, puppeteer, trumpeter,

34. For the Parva passages, see the references assembled in OJED, s.v. walätkāra. The attestations in inscriptions from Bali are pamalatkaran in the Bebetin AI plates (Goris 1954, no. 002 - in Old Balinese), line 2r5 and amalatkara in the Gurun Pai plates (van Stein Callenfels 1926: 14-18 — in Old Javanese), 3v5-3v4.

35. See Nothofer (1975: 314): "According to Professor Noorduyn Old Sundanese has tarema." An instance is RR.808 akiin gas katarema, ku niain panhaat kita "Grandfather, I am most grateful for your kindness."

36. The OS word same seems to correspond to sāmya in OJ. Zoetmulder (OJED, s.v. sāmya) notes: "It seems to be a person (group of persons, para sāmya) with some authority on a lower (village?) level, subaltern official or chief. They are mentioned with kuwu and juru. Cf. OJO 61 (distinguished from tanayan thāni)." 
gamelan musician, drummer, joker, dry rice field farmer, palm tapper, wet rice field farmer, sweeper, death defying solder (? belamati), magician, barat katiga, soldier, blowpiper, archer, warrior, collector of dasa and calagara (penalties), children of shepherds, pig farmers, chicken farmers, fisherman, diver, [and] all those who are of use. If there is anyone who has the virtues of fidelity, etc., in service, it is he who is to be followed, for he is dedicating himself to the country." In the two SKK passages, it seems that dasa and calagara indicate a certain type of penalty, as we find in our inscription, as opposed to the SMG passage where it rather seems to designate the persons liable to pay such penalties. 1v4. timbam $\diamond$ Hardjadibrata (2003, s.v.) defines the term timbang as a kind of measuring unit for rice paddies, equivalent either to $1 / 2$ or 1 pikul weight of paddy depending on the source. In MdS, one pikul has a weight of approximately $61.75 \mathrm{~kg}$. 1v4. domdam $\diamond$ Pleyte (1911: 199) records that he found the term peso dondan in an Old Sundanese text. Although the context of his discussion implies that he found peso dondan in SMG, we have only found the term attested in SKK.17, where it is listed among items held by the religious teacher: gangamam san pandita ma kalakatri, peso raut, peso dondan (?), pañot, pakisi, danava pinakadevanya, ja itu paranti kumərət sagala "the weapons of the scholar (pandita) are the betel nut cutter (kalakatri), raut knife, dondan knife, pañot, spike (pakisi). The Danawas are their deities, for they are utilised to cut everything." Pleyte assumed that a peso "knife" being used for dondan means that the word dondan in this passage cannot have the meaning "tray" that is recorded, i.a., by Eringa (1984, s.v. dongdang 2): "kind of (long wooden or bamboo) carrying tray (carried on a pole by two men, for transporting plates or edibles etc. at feasts and slametans)." ${ }^{37}$ See also Ensiklopedi Sunda (Ajip Rosidi 2000: 200) for a description and a drawing. Unfortunately, the meaning of the segment peso dondan is particularly unclear, so that it hardly helps to interpret our inscription. Considering that timban is a unit of measurement, dondan might concretely mean a unit of paddy corresponding to the volume of a dondan. This implies that dondan is more voluminous than timban.

1v4. ditudi $\langle\dot{m}\rangle \diamond$ See OJED s.v. tudin "index," anudini "to point the finger at (esp. with the left hand in challenging)"; tudin in MdS means "accuse someone," but in this context "addressed to" seems better. It is interesting that Pleyte (1911: 163 n. 4) related ditudin to tuduh in MdS, which could also means both "to address, to indicate" and "to accuse someone."

1v4. para muhara $\diamond$ We are inclined to consider para muhara as a short equivalent of a hypothetical construction muhara para muhara which would mean "various river mouths." See de Casparis 1991: 38-41 on such constructions of para in OJ epigraphical sources. Both the full construction and the shortened equivalent are also recorded in OS texts. Cf. CP.45a: dayəh para dayzh, desa para desa, nusa para nusa, ti kalin bakti ka rahyañtan் kuku "various cities, various regions, various islands, from Keling venerated Rahyangtang Kuku"; and BM.917-919: bətən் rəəs ku sakitu, bogoh ku nu mava iña, bibijilan para nusa "after admiring all these things, I was attracted

37. We translate from Eringa's Dutch, because the dongdang entries in Hardjadibrata (2003) seem to have suffered some (technical?) mishap leading to the loss of most of the second entry. Rigg (1862, s.v.) has: "a cage or contrivance made of bamboo to carry out eatables with dishes \&c; also to carry about boxes of clothing \&c. to preserve them from sun and rain." 
by the crew, they came from various islands." The persons from such places may be implied in this construction, as in KS.2.18: palana ka puhavan, ka para desa, ka malayu, mo monan mo vaya-vaya sakti nabiyapaka "the result of it for the ship master, for [the people from] various regions, for [the people of] Malayu, is that they will not be able to pervade their forces." This is why we translate para muhara as "the [people from] various river mouths."

2r1-2. dibuhaya $\diamond$ The meaning of dibuhaya is problematic for several reasons, and this word only appears in Kebantenan (dibuhaya and mibuhayakən), and Bujariga Manik (dibuhaya). The first difficulty concerns the function of the prefix. In OS, as in $\mathrm{MdS}$, forms with $d i$ - can have both active and passive meanings. The most common function is to form a passive verb. However, it should be noticed that the absence of an object in the sentence suggests that dibuhaya may be an active intransitive verb, as is the case for diprain "to go to battle," diajar "to learn," dibuah "to bear fruit, ditapa "to practice asceticism" and many other examples (see Noorduyn \& Teeuw 2006: $35)$. The second difficulty concerns the meaning of the base. The only occurrence for comparison is found in BM.15-17: ambuin tatanhi tingal, tarik-tarik dibuhaya,

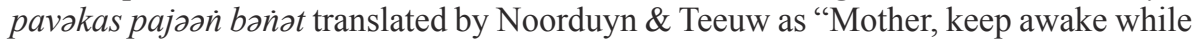
staying behind, even if you pull as strongly as a crocodile, it is the last time we see each other face to face." Obviously we do not expect any meaning like "as strongly as a crocodile" here, even if all the MdS dictionaries record buhaya "crocodile." In the context of this inscription, the word can be understood in the light of buhaya in OJ (OJED, s.v. buhaya I), whose derived form (m)abuhaya means "love-smitten, pining, languishing." We presume that buhaya is also related to Malay buai "swaying, swinging, the motion of pendulum," and the verb berbuai "to swing" (Wilkinson 1959, s.v. buwai). On this basis, we propose that OS dibuhaya may mean something like "to cherish, to treat gently, to treat with care" if it is active, or "be cherished, be treated gently, be treated with care" if it is passive. The fact that mibuhayakan, the active transitive form of buhaya, occurs here immediately after dibuhaya reinforces the notion that the vikus treat the rules of proper conduct (kacaritaan) with great care. Compare also the choice of the word heman in Keba2.1v5, which expresses the king's affection for the hermits. Thus, we propose to translate kena Iña nu purah dibuhaya, mibuhayakan' na kacaritaAn' as "because [the hermits] are the ones who are assigned to be cherished [by the king], who cherish the code of conduct" as the first alternative, or "because they are the ones who are assigned to cherish, (i.e.) who cherish the code of conduct" as the second option. Consequently, the words tarik-tarik dibuhaya in the BM passage could be translated as "[even if we] cherish each other strongly" or "[even if we] are strongly cherished by each other."

2r2. kacaritaan $\diamond$ See our discussion in $\$ 4.2 .7$.

\subsubsection{Kebantenan no. $2=$ MNI E. 43}

The inscription was read first by Holle (1867b: 562, Plaat I) and then by Pleyte (1911: 169). Boechari (1986-1987: 104-105) provided a new reading although without any translation. The most recent reading is the one by Hasan Djafar (1991: 11), now with Indonesian translation. Our new reading is based on Leiden rubbings and a photograph. It is engraved on both sides of a copper plate measuring $21.5 \times 6.7 \mathrm{~cm}$ : the recto has six lines, and the verso has five. 


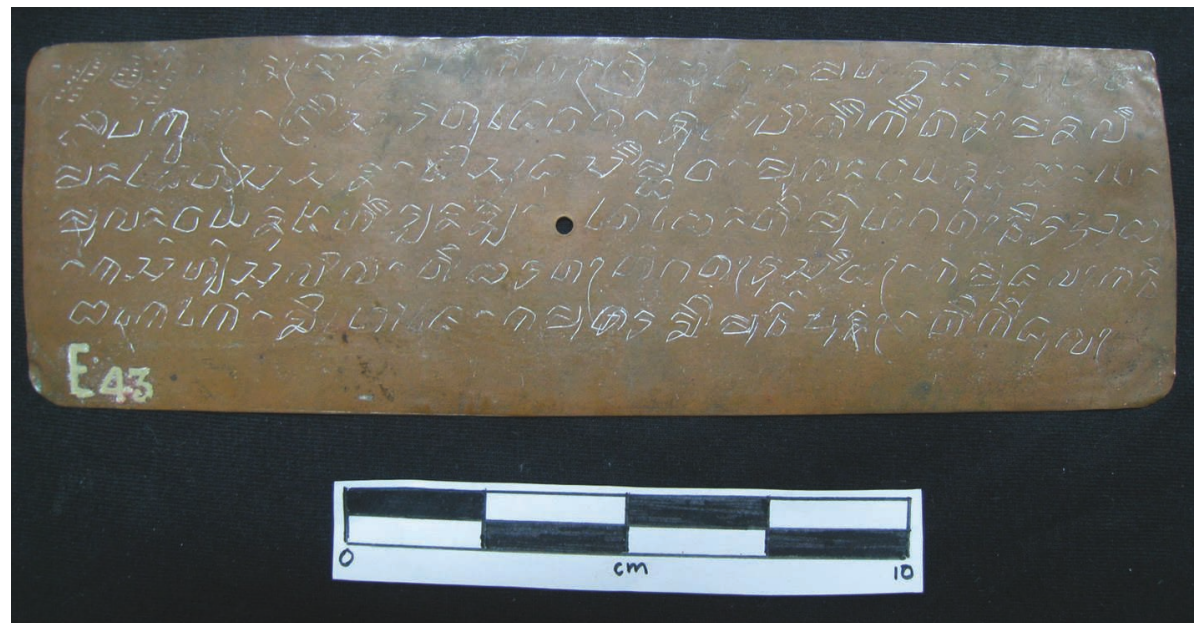

Fig. 10 - Kebantenan no. 2 (MNI E 43 recto, photo by Terrylia Feisrami).

\subsubsection{Text and apparatus}

\section{Plate 1, recto.}

(1) // Ø // pun· Ini pitəkət· śri buḍuga maharaja ratu haji

(2) ḍi pakvan', śri sam ratu ḍevata, nu ḍipitəkətan· ma na lə-

(3) mặ ḍevasasana, ḍi suくn’ḍasəmbava, mulah vaya nu nubaḥ ya,

(4) mulah vaya nu nahəryanan ya, $\bigcirc$ tebeh timur hamgat ciraAb

(5), ka sam hyam salila, ti barat $\cdot$ hamgat $\cdot$ ru<m $>$ səb $\cdot$, ka murñ jul $\cdot$ ka ci-

(6) bakekem, ciho<ñ >je, ka mu(ha)ra cimu<ñ >cam pun·, ti kiḍul·

\section{Plate 1, verso.}

(1) hamgat· Ĺvəm comon', mulah mo mihape ya, kena

(2) na ḍevasasana samgar kami ratu, saparah jalan· gə⿱亠巾e,

(3) kagiramkkən', L̊maḥ laramn் $O n \cdot$ pigəsanən·na para viku

(4) pun', Ulaḥ ḍek· vaya nu kəḍə ḍi bənaminim nagurat· ke-

(5) naIm heman', di viku pun·

1r1. śri $\mathrm{P} \diamond s r i \mathrm{H} \mathrm{B} \mathrm{HD.} \mathrm{-} \mathrm{buduga} \diamond$ baduga H P B HD. Looking at the element baduga in Batutulis, it is clear that buduga here must be an error, which all previous editors have either failed to notice or silently corrected. OS manuscripts always have baduga (cf. CP.30a, AG.1v). This word is probably a Sundanese development of Skt. pāduka. 1r2. śri $\mathrm{P} \diamond$ sri H B HD. — ma na $\diamond$ All predecessors read as one word, mana, on which B and HD note "Maksudnya: nana". See §3.2.1. - 1r2-3. lamah $\diamond$ The word is spelt here with consonant $l$ plus pamepet, rather than with aksara vowel as in 1v3 Lmah. - 1r3. di $\mathrm{H} \mathrm{P} \diamond$ om. B HD. - vaya H P HD $\diamond$ Aya B. - nubah ya $\mathrm{H} \mathrm{P} \mathrm{HD} \diamond \dot{n} u p a h y a$ B. - 1r4. vaya $\mathrm{H} \mathrm{P} \mathrm{HD} \diamond$ Aya B. - 1r4. niahrryanan ya $\diamond$ naha:ryanan. $\mathrm{H} \mathrm{P} \mathrm{B} \mathrm{HD} \mathrm{-} \mathrm{tebeh} \mathrm{H} \mathrm{P}$ 
$\diamond$ te beh B HD; B and HD note: "te [baca: $t i]$ beh", but the word tebeh is commonly used in OS texts. Cf. BM.662, 1082, 1160. - ciraAb $\diamond c i r a U b$ H P B HD. The third basic aksara is $A$. It seems that a small stroke below its right element is interpreted as panyuku by all predecessors, which would mean $q u$ in our system. But we are inclined to read only $A$, since the aksara $U$ has its own shape in this plate (see Ulah in 1v4; see also the appendix). - 1r6. mu(ha)ra $\diamond$ The aksara $h$ in this word is badly executed. The engraver seems to have first written $r a$ and then tried to correct his mistake by changing it into ha. -1v1. Lvam $\diamond$ la:va: $\dot{m} \mathrm{H}$ P B HD. — mo mihape ya HD $\diamond$ mo mihapeya $\wedge>\mathrm{H} \mathrm{P}$; mo himapeya<n> B. - 1v3. kagiramkan $\diamond$ kagiramka:n H P B HD. — laraminan $\diamond$ larañan H P B HD. — pigəsanən`na $\diamond$ pigə:sanə:n`na HD; pigə:sanə:nna H P B HD. — 1v4. vaya $\mathrm{H}$ P HD $\diamond$ Aya B. — kadə $\diamond k a d ə:$ P; kə:də: H B HD. — bənaminim $\diamond$ bə:naminim P HD; bə:nanim H B. — 1v5. kenaIm $\diamond$ kenana Im $\mathrm{H}$; kenana Aim $\mathrm{P}$; kena AIm $\mathrm{B} \mathrm{HD}$.

\subsubsection{Translation and commentary}

This is a decree of Sri Baduga Maharaja, the king of kings of Pakuan, Sri Sang Ratu Déwata. That which is made the object of decree is the land of divine ordinance, [namely] Sundasembava. May no one change it, may no one burden it. On the east side, the limit is the Ciraab to the Water deity (sain hyan Salila - i.e., the Sea?); on the west the limit is the jungle (runisab) to Munjul, to Cibakékéng, Cihonjé, until the Cimuncang estuary. From the south, the limit is the haunted forest (ləvən comon). Do not fail to take care of it! Because [the land] of the divine ordinance is the shrine of me, the king. Along the highway to its upstream, [it is] the forbidden land that will serve as place of the hermits. May no one be aggressive to my work of restricting, because I have affection for the hermits.

1r1. pitzkat $\diamond$ In OS, this word is often mentioned side by side with the word talatah "message," as in SC8r: kena iña tañtu san sida karuhun, talatah saí sida sukma, pitəkət sain sida ləñap "for that is the rule of the deceased ancestor, the message of the deceased soul, the exhortation of the deceased who has vanished." In OJ, pitzkat means "(the drawing of so.'s attention) exhortation, advice, warning" (OJED, s.v. někět), or in other words, "a decree." Cf. MdJ piagəm, and nihan sakakala in the opening of Keba1, with our comment on sakakala in BaTu.1.

1r3. $s u<n>$ dasambava $\diamond$ See our comment under Keba1 (\$4.2.2).

1r4. hamgat $\diamond$ The word is no longer known in MdS, but in all OS contexts, it means "border, limit." Among many occurrences in FCP, we cite as example FCP.3b: alasna donuh ti barat hangat cipahenan ti hulu cisogon alasna puntañ ti timur hulu cipalu ti kaler hangat hulu cilamaya "the domain of Denuh: in the west the limit is Cipahéngan from the upper Cisogong. The domain of Puntang: in the east [the limit] is the upper Cipalu, in the north the limit is the upper Cilamaya." The word must be related with the group of Malay words enggat, senggat, tenggat, that express similar meanings (Wilkinson 1959, s.vv.).

1r4. ciraAb $\diamond$ This river name is derived from the word raab, which is presumably related to MdS rahab "provide so. with necessities." Toponyms Ciraab or Cirahab still exist in several areas, both in West Java and the western part of Central Java. 
1r5. $r u\langle\dot{m}\rangle s a b \diamond$ HD leaves this word without translation, considering it as a toponym. But it can be equated with rungseb in MdS. "bony, prickly, thorny; fig.: stinging, caustic, snide (of a remark etc.)." In the context, a common noun meaning "jungle" seems fitting. 1v1. lavam conom $\diamond$ This seems to mean "haunted forest." Cf. MdS leuweung onom, which has this meaning. We suppose that the word comon has become womon at some stage, because of the interchangeability of $/ \mathrm{w} /$ and /c/ observed in the history of Sundanese (caringin = waringin, cai = wai, see our comments on calagara in Keba1), before finally becoming omon in MdS. The word runsab "jungle" in 1r5 will then be a quasi synonym.

1v2. samigar $\diamond$ Cf. SKK.18: hayan் ñaho di puja di sangar ma: patah puja daun,

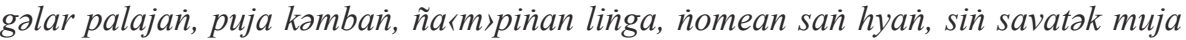
ma ja<i் gan taña "If one wishes to know about the offerings in the sangar: the arrangement of a leaf offering, palajan offering, flower offering, putting a cloth on linga, maintaining the deity, all kinds of offerings, ask the jaingan." Cf. also SC.1125 quoted in our comment under BaTu.7. These passages suggest that saingar means "shrine," as in OJ. MdS has the particular meaning "offering place (of wood or bamboo on high stilts, also of a basket fixed on a bamboo pole, built before harvest on the rice field, consisting of the puncak manik with various spices and toilet-articles for Nyi Sri); nyanggar place offerings on the sanggar."

1v4. kədə $\diamond$ Cf. CP.12a: təhər bava ku kita kədə-kədə! "Then you should take [it] by force!"; AG.1r: mulah pabvain pasalahan paksa, mulah pakado-kado, asin ra«m〉pes, cara purih, turutan, mulah kada di tinən di maneh, isəs-isaskan carekna pa«nıtikrama, "Do not reject (some one) who has the wrong ideas, do not be aggressive toward each other. Whoever is decent, as one is supposed to be, follow [him]! Do not be obstinate with your own ideas. Pay attention to the words of propriety (pantikrama)." Cf. OJ kad̄ "feeling the urge to, feeling impelled to, set on; (wanting, seeking to obtain, etc) at all costs (by any means); keeping on, cannot but ..., unremittingly, insistently, obstinately, unavoidably" (OJED, s.v. kédö). It seems that the OJ/OS word survives into MdS keudeuh as a synonym s.v. keukeuh "obstinate, stubborn, tenacious, unyielding; kumeukeuh s.m.; keukeuh peuteukeuh/kedeuh/ keudeuh s.m. (emph.); ngeukeuhan hold on to st., stay with st., stubbornly ask about st.; pakeukeuh-keukeuh both sides stubbornly stand firm (maintain their stand)." Cf. also MdS \& MdJ kudu "must, have to, need to, should, ought to."

1v4-5. kenaIm $\diamond$ For an explanation of the pronominal suffix -in (corresponding to pronoun ain), see Noorduyn \& Teeuw 2006: 48.

\subsubsection{Kebantenan no. $3=$ MNI E. 44}

The inscription was read first by Holle (1872: 367-369, Plaat V), following his previous reading of other plates (1867b). Subsequently, Pleyte (1911: 170) gave a new reading and Dutch translation. Boechari (1985-1986: 104-105) provided a new reading although without any translation. The most recent reading is the one by Hasan Djafar (1991: 11), now with Indonesian translation. Our reading is the result of autopsy by Aditia Gunawan on May 23rd, 2013. Alas, no usable reproduction is available for this plate, which is extremely thinly engraved and therefore hard to photograph. It is engraved on both sides of a copper plate measuring $14 \times 5.3 \mathrm{~cm}$ : the recto has four lines, and the verso has two. 


\subsubsection{Text and apparatus}

\section{Plate 1, recto.}

(1) Ini pitəkət( $)$ nu (s)eba ḍi pajajaran· mi(t)ə(k)ə-

(2) $\tan (\cdot)$ ti kabuyutan $\bigcirc$ ḍi su<n>ḍasombava, aya ma nu naba-

(3) yuAn· mulạ $\mathrm{A}(\mathrm{ya}) \bigcirc$ nu ñəkapan ya, mulaḥ aya

(4) nu munaḥ-munaḥ Iña, nu ṅahəryanan·, lamun aya nu

\section{Plate 1, verso.}

(1) kəḍə pa<L১baḥna luraḥ su<n〉ụasəmbava, ku ṅaIm ḍititạ̣ ḍipaEḥ-

(2) han', kena Eta lurah kavikvan',

1r2. $t i \diamond k a$ P; na H B HD. - 1r2-3. nabayuAn· H B HD $\diamond b a b a y u A n \cdot \mathrm{P}$ - 1r3. mulah A(ya) nu ñəkapan ya $\diamond$ om. P; mulạ̣ Aya nu ñəkapan. H B HD. - 1 r4. nahəryanan $\diamond$ hahə:ryanan. H P B HD; HD add a note "[baca: nahöryanan·]." 1v1. pa<L〉bahna $\diamond$ pa<m>bahna $\mathrm{H}$; paambahna $\mathrm{P}$; pa<am $b a h n a \mathrm{HD}$. We prefer to assume that an aksara $L_{0}$ has been omitted by the engraver, since the aksaras ba and $L$ are quite similar in shape, so that we can understand palabahna as in MdS "place where something is located." Cf. also the functionally equivalent use of $d i$ in Keba2.1v4 kado di bonaminim n்agurat. — 1v1. ku naIm $\diamond k u$ AIm H P B HD.

\subsubsection{Translation and commentary}

This is the decree of one who renders service to Pajajaran, issuing the decree from the sanctuary of Sundasəmbava. If there is anyone who provides livelihood [to it], may no one be impudent to him. May no one kill him [or] obstruct him. If anyone is aggressive to (palabahna) the domain of Sundasombava, he is commanded by me to be killed, for that is the domain of the hermits.

1r1. $n u(s) e b a$ di pajajaran. $\diamond$ Our predecessors considered that nu seba di pajajaran is the king mentioned in the other Kebantenan inscriptions, but they seem to have overlooked the fact that this decree, by contrast with the other ones, is issued from a kabuyutan. In our opinion, nu seba di pajajaran is not the king of Pajajaran but a single local-level officer (note his use of the first person singular pronoun ain), who renders service to the king of Pajajaran, as a confirmation of the king's decrees. Cf. MdS séba "gift that is offered as a tribute (to the authority, head of government)." The expression nu seba also occurs in RR.1024-1025 nu rea di pada handap, di lomah mayak nu seba "the people were on the lower platform, on the ground, those who serve are sitting."

1r3. ñakapan $\diamond$ Cf. SKK.11: aya ma janma paeh malin, paeh papañjinan, paeh nabegal, paeh meor, sin savatzk cəkap carut, eta jəə⿱亠䒑 kena ulah diturutan "If there are people who die while stealing, die while cheating, die while robbing, die while tricking(?), all kinds of impudent and evil [acts], pay attention to it for it should not be followed." Cf. OJ cəkap "impudent” (OJED, s.v. cěkap). In MdS nyekapan means "provide so. with the necessities," and is a polite (lemes) variant of nyukupan (from cukup). 
1v1. $k u$ naIm $\diamond$ For occurences of $\dot{n} a I \dot{m}$ instead of ain, cf. BM, RR, SRD, CWG passim, and the specific examples cited in $\$ 4.1 .2$ and $\mathrm{n}$. 35. It is important to note that the variant $\dot{n} a I m$ in these texts only occurs after the words $k u$ and $k a$ (see Noorduyn \& Teeuw 2006: 47). However, this does not mean that $k u$ ain never occurs: we find it in CP.42a and CWG.265.

\subsubsection{Kebantenan no. $4=$ MNI E. 45 , recto}

The inscription was read first by Holle (1867b: 564), and then by Pleyte (1911: 197). Boechari (1985-1986: 106) provided a new reading although without any translation. The most recent reading is the one by Hasan Djafar (1991), now with Indonesian translation. The new reading offered here was made by Aditia Gunawan based on autopsy on May 23rd, 2013. No reliable visual documentation is available. The verso side is not entirely legible because the writing is very worn out. Each side of the plate seems to contain an independent text, so we give the text on the verso a new number, Kebantenan 5. Kebantenan 4 and 5 are engraved on the two sides of a copper plate measuring $20.5 \times 6.5 \mathrm{~cm}$, and both consist in eight lines of writing.

\subsubsection{Text and apparatus}

(1) // Ø // pun· Ini pitəkət· sri baḍuga maharaja ratu haji ḍi pakvan· sri sam ratu $\lceil-$

(2) ḍevata, nu ḍipitəkətan· ma na Ĺmạ̣ ḍevasasana, ḍi gunum samaya sugan'n aya

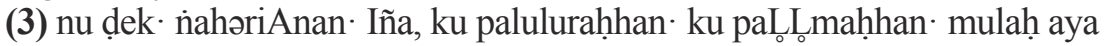

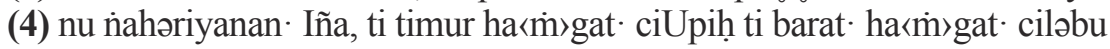

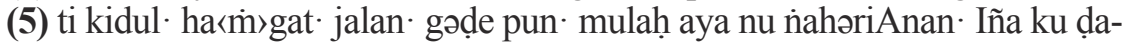

(6) sa ku calagara Upəti pamgəRs · Roma Ulah aya nu me〈n`taAn· Iña 「-

(7) kena, samgar kami ratu nu purah mibuhayakən· na karatu(ya)n· nu pagəh navakan.

(8) na devasasana pun· $\varnothing \varnothing$

2. ma na $\diamond$ mana H P B HD; B \& HD with a note: "[baca: nana]." - 2. sugan $\cdot n$ aya $\mathrm{HD} \diamond$ sugan aya $\mathrm{H} \mathrm{P}$; sugana $\mathrm{B}$ - 3. nahəriAnan $\diamond \mathrm{H} \mathrm{P}$; nahə:riyanan. $\mathrm{B}$ HD. - 4. nahariyanan $\diamond \dot{n a h a: r i A n a n \cdot H ~ P ; ~ n a h ə: r i y a n a n ~ B ~ H D . ~-~ 4 . ~ c i l a b u ~ H ~ P ~}$ $\diamond$ ciLbu HD. Here lo is formed by aksara $l$ and pamepet. Note that Holle and Pleyte did not actually distinguish between $l o$ and $L_{0}$. - 5. nahoriAnan $\diamond \dot{n} a h$ s:riAnan. $\mathrm{H}$; hariAnan $\mathrm{P}$; nahə:riyanan. B HD. - 6-7. kena, samgar $\diamond$ kena samgar $\mathrm{H} \mathrm{P}$ $\mathrm{B}$ HD. The punctuation mark after the word kena is superfluous because the word kena "for, because" is a conjunction. - 7. mibuhayakan. na $\diamond$ mibuhayaka:na $\mathrm{H}$;

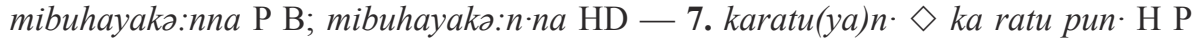
B HD. This part is not clear due to the fourth aksara being very faint, but when Aditia Gunawan inspected the plate he did not see any panyuku, and observed that the character has three vertical strokes. 


\subsubsection{Translation and commentary}

This is the decree of Sri Baduga Maharaja, the king of kings in Pakuan, Sri Sang Ratu Déwata. That which is made the object of decree is the land of divine ordinance on Mount Samaya in order that there may be no one who burdens it by the taxes of territory (palulurahan) [and] by the taxes of land (palolomahan). May no one burden it: in the east the limit is Ciupih; in the west the limit is Ciləbu; in the south the limit is the highway. May no one burden it by dasa, by calagara, tribute (upoti), and levies on fallow rice-field land (pangzrəs rəma). May no one ask them [such taxes] for that is the shrine of me, the king, who am the one to cherish the kingship, who firmly practice the divine ordinance.

3. palulurahhan $k u$ paLLmahhan $\diamond$ It is interesting to note that the respective base words here, lurah and lomah, are also used elsewhere in this group of inscriptions (Keba3.1v2 lurah kavikvan, Keba4.2 lomah devasasana). In OJ, the circumfix pa- -an is used to form several terms connected with tax, although never with reduplication, e.g. paramasan, paragəpan, pamadihan.

5. paigəRs $\cdot$ rəma $\diamond$ We hypothesize that the base word gərəs is equivalent to garis and gores in Malay and geret in MdS. Hardjadibrata (2003, s.v.) defines the latter as "notch, indentation, stripe, scratch; stroke, flourish (of a character); ngageret make a notch on/ over st, notch st." It is important to notice that Hardjadibrata also records the meaning "delimit st. with a stripe, indicate/mark the limit of st." The term roma in MdS means "left (and overgrown again with underbrush and weeds) block of arable land (esp. a dry rice-field that hasn't been planted for more than two years); fallow rice-field land." We presume that pangəRs $R_{0}$ Rma is a tax levied on fallow dry rice-fields, possibly calculated with reference to the area of rəma. Cf. the OJ term carik huma which literally has a similar meaning, attested in the Adulengen plates (945 Śaka) and Padlegan I stela (1038 Śaka). See OJED, s.v. Pleyte relates the term garəs with roris "to inspect, look over";

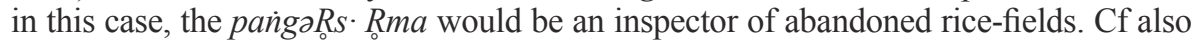
SKK.9 quoted in our comment to dasa calagara in Keba1.1v3.

7. navakan $\diamond \mathrm{Cf}$. SC.882-884 emet imət raja〈n〉 lakən, pakagəin na ditapa, navakan

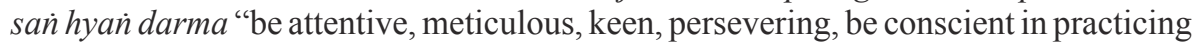
asceticism, in practising the holy dharma."

7. karatuyan $\diamond \mathrm{We}$ assume that this is a variant spelling of karatuan. See our discussion in \$3.1.3. Also compare the nearly identical structure seen in Keba1.2v2: mibuhayakan' na kacaritaAn. "to cherish the code of conduct" applied to the hermits, while in the present context, it is the king who cherishes the kingship.

\subsubsection{Kebantenan no. 5, MNI E. 45, verso}

See the description in $\$ 4.2 .5$. Among our predecessors, only Pleyte (1911: 197, bijlage 2) read this text. 


\subsubsection{Text and apparatus}

(1) // o // _ _ ni pitəkə______ maharaja ratu haji ḍi

(2) kuvan.

(3) samapun.

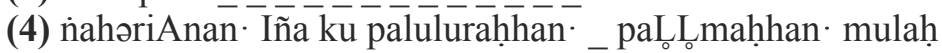

(5) Aya nu nahəriAnan- Iña ti timur hagat ciUpih ti barat lurah cira

(6) _ _ Ltik · lor hamgat jalan' gəḍe pun' mulah vaya nu nahəriyanan·

(7) I

(8) mibuhayakən' na (Àdi paI)

1. ni pitəkə_ $\diamond$ pitəket $\cdot \mathrm{P}$; restore Ini pitəkət $\cdot$ ? _ _ _ maharaja $\diamond$ sri baduga māharaja $\mathrm{P} . \_$ratu haji di $\diamond$ om. P; 2._kuvan $\bullet \diamond$ pitzkətan $\mathrm{P}$; restore pakuvan $\cdot$ 3. samapun $\diamond \diamond_{-}$ma pun sa P. - 4. _paLLmahhan $\diamond$ ku paLLmahan $\cdot \mathrm{P}$ - 5. lurah $\diamond$ hamgat P. - 5-6. cira_ $\diamond$ restore ciraAb ? - 6. Ltik $\cdot$ lor $\diamond$ ti kaler P. - 7. I_ $\diamond$ Iña P. - (Adi pal) $\diamond$ Adi pun $\cdot \mathrm{P}$.

\subsubsection{Commentary}

Boechari notes at the end of the recto: "kata pun ini menunjukkan bahwa prasasti berakhir di sini. Tetapi sisi belakangnya masih ada tulisan tipis yang bertumpuk dengan bekas piagam lama dan sukar sekali dibaca". While we could read only a few parts, we suspect that the two sides of the plate contain a different text, although, at first glance, they appear the same. For example, the word samapun in $\mathrm{v} 3$ corresponds to nothing on the recto; also, after mentioning Ciupih as the eastern border, the western limit on the verso is different from Cilabu as we find on the recto, but begins with the string lurah cira_ (perhaps "the territory of Cira[ab]"?). Moreover, the highway (jalan gade) here seems to be the northern limit (v6: lor hamgat jalan gade), while in $\mathrm{r} 5$ it is the limit in the south. These modest findings make it possible to formulate two alternative hypotheses: either the inscription on the verso contains a decree for a different area from that on the recto, and consequently mentions partially different boundaries, or the two texts actually refer to the same area. In the first case, it can be assumed that the area intended on the verso was located south of Mount Samaya. In the second case, we can imagine that the text on the verso is a rejected draft of the inscription which was rewritten on the recto, especially regarding the area's borders.

\subsubsection{The Hermitage}

The most crucial information contained in the Kebantenan charters concerns the relationship between the Sundanese king and religious institutions. Through these decrees, the religious domains, which were likely situated in the mountains (as suggested by the mention of toponyms such as Mounts 
Samaya and Jayagiri) ${ }^{38}$ received special privileges. The religious domain is called lomah devasasana, and since all the divine rules are to be practiced there by the hermits (viku), it is also called a "hermitage" (lurah kavikvan). If we look to eastern Java, the Deśavarnana (1365 CE) enumerates different types of religious establishments (Cantos 75-78). Pigeaud argued that the poem's author, Mpu Prapañca, makes a distinction between domains and sacred places placed under the authority of some court official (rinaksa), and independent (svatantra) communities (Pigeaud 1960-1963, IV: 228, 253). It is probably the former scenario that we encounter here in 15th-century Sunda, as the king explicitly states that the land under his protection is his official shrine of worship (saingar kami ratu).

These texts state that the devasasana was practiced by both hermits and kings. The Carita Parahyanan narrates how king Niskala Wastu Kancana, the king recalled in Kebantenan 1 as the grandfather of Sri Baduga Maharaja who issued the decrees, brought prosperity and peace in various domains of social life, including freedom in religious practice:

\begin{abstract}
ña mana sà் rama enak mañan, san் rosi enak ṅarosisasana, ṅava/kan na purbatisti purbajati, san் disi enak masini, ñavakan na manusasana, naduuman alas pari alas, $k u$ beet hamo diukih, $k u$ gade hamo diukih, ñ mana san tarahan enak lalayaran, ñavakan

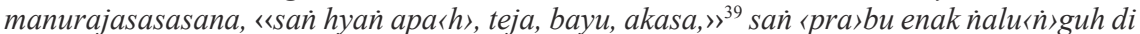

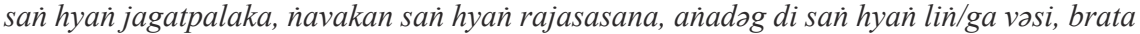

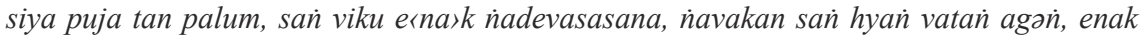
nadag〈kən〉 manurajasunya. (CP.22b-a)
\end{abstract}

Therefore the elders are at ease to eat; the ascetics are at ease performing the ordinance of asceticism, practicing the original rule and original state of existence; the disi is at ease to deliberate, practicing the ordinance of Manu, allotting all kinds of forest tracts: [he] cannot be vanquished by subtle [enemies], cannot be vanquished by the gross [enemies]. Therefore the seamen are at ease to sail, practicing the ordinance of the rajasa men. ${ }^{40}$ The king is at ease governing as the protector of the world, practicing the holy ordinance of the king, standing on the holy linga of iron, he performs continence and worship without being dejected. The hermits are at ease practicing the divine ordinance, practicing the great book, at ease to make firm the manurajasunya.

The ideal image of the conditions under Niskala Wastu Kancana's reign implies that his grandson might have felt compelled to guarantee their maintenance. Both the Kebantenan texts and the Carita Parahyanan confirm

38. We are unable to offer a convincing localization of these mountains on a modern map.

39. The segment enclosed in «(...» seems intrusive and would probably have to be deleted in a critical edition. We ignore it in our translation.

40. The term manurajasa may be a synonym of von rajasa "a particular corps of troops" (OJED, s.v. rājasa). The Kidun Harșavijaya 1.55a mentions it among other kinds of military officials: von் sinzlir bayankkara lan von jayasari sinhajaya ndatan kari von rajasänlurug in malayu "The chosen men of the bayangkara corps with the victorious men of the singhajaya corps, not to mention the men of the rajasa corps went to attack Malayu." 
that hermits are a group practicing the devasasana. In the $\mathrm{CP}$ it is quite clear that devasasana is a doctrine, while the term lamah devasasana in the inscriptions refers to the region where the devasasana is practiced.

Hardly any data is preserved in other Old Sundanese sources to interpret the meaning of devasasana. We are a bit luckier if we consult contemporary Old Javanese sources. The definition of devaśāsana is furnished in an unpublished text called Rssiśāsana (§2):

devaśāsana ṅaranya, śáśana san saugata, māheśvara, mahābrāhmana, salvirnin samayi, putraka, sādhaka, pitāmahā, bhațāra parameśvara, salvir dạn hyaì salinisinan, vulusan, tigà rāt, raja, jambi, air bulan், air asih, man்ulihi, taji, kamūlan , parhyañan, devaśāsana naranikā /I

We call devaśāsana the precepts for the Buddhists, the Māheśvaras, the Mahābrāhmaṇas, all of the [four initiatory levels] of the Lord Parameśvara [namely] the neophytes (samayin), the fully initiated disciples (putraka), the fully initiated yogic practitioners (sādhaka), the

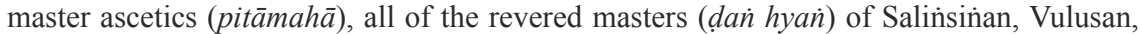
Tigan Rat, Raja, Jambi, Air Bulan, Air Asih, Manulihi, Taji, of the kamūlans, of the parhyañans. Those [precepts] are called Devaśāsana.

(ed. and transl. from Marine Schoettel's ongoing work toward a $\mathrm{PhD}$ dissertation)

This passage of course leaves much unclear about the meaning of devasasana. However, it seems noteworthy that the term is explicitly defined as ecumenical, namely as pertaining to various men of religion: Śaivas, Buddhists, ascetics, students of various levels, and various other religious functionaries.

One of the Kebantenan texts also mentions that the hermits in the area protected by this king cherished kacaritaan. It seems that the word carita in kacaritaan does not mean "story" as is usually the case in MdS. We assume that the meaning of the word here is closer to that which the word has in Sanskrit, namely "acting, doing, practice, behavior, acts, deeds, adventures; fixed institute, proper or peculiar observance" (Monier-Williams, s.v. carita). Such meanings are required to understand the shift toward the sense "sphere of activity, habitat" that we find in a stanza in SKK.15:

tatakam carita hamisa, gajendra carita banəm,

matsyanəm carita sagarəm, puspanəm carita bai்barəm

The pond is the habitat of the goose; the forest is the elephant's habitat; the sea is the habitat of fishes; flowers are the habitat of the bee.

Moreover, there is a clue about the relation between viku with carita in SKK.20, which provides a picture of the viku's duties and functions:

hayan் ñaho di sandi, tapa, lunguh, pratyaksa, putus, tankkss, kaləpasən, ${ }^{41}$ tata hyan, ${ }^{42}$

41. It should be noted that this sequence, although somewhat different, is systematized into five segments (vuku lima) in the SKK.4, namely sandi, tapa, lunguh, pratyaksa and kalopason. Cf. also the OJ text Saì Hyan் Hayu $\$ 49$ (in Undang A. Darsa 1998: 205).

42. The words devata and hyan can mean "god" in a general way, but in case of a hierarchical relationship, as in SKK, we see in Old Sundanese that hyan should be interpreted as "ancestor" or "holy spirit." Cf. LiWa below, and further SSK.2 man்ku bumi bakti di ratu, ratu bakti di devata, 
tata devata, rasacarita, kalopacarita, sin savatzk nata-nata para devata kabeh, sañ viku paraloka taña

If one wishes to know about sandhi, asceticism, posture, vision, completion, epitome, liberation, the position of the ancestors, the position of the gods, the practice of feeling, the practice of ritual (kalapa), all types of arranging all gods, ask the otherworldly hermits (viku paraloka).

The chapters of the Old Javanese juridical text called Svayambhu (of which an edition and translation is being prepared by Arlo Griffiths in collaboration with Timothy Lubin) bear titles ending in -carita (dharma-carita, maryādacarita, etc.), where the word means the rules/customs on a given topic. Based on the aforementioned usages of carita in Old Sundanese and Old Javanese, we assume that kacaritaan refers to the religious traditions adhered to by the vikus.

It is also interesting to note that one of the toponyms for one of the territories under the King's protection is Sundasembawa, which literally means "the origin of Sunda." This word reminds us of a more local equivalent of the word with the same meaning, sunda wiwitan, a term used for the religion of the Baduy (Kanekes) people in Banten today, whose practices seem in many ways seem to be vestiges of those that would have been current all over the Sunda area in pre-Islamic times (Saleh Danasasmita \& Anis Djatisunda 1986). The relationship between the court and religious institutions should, if possible, be further explored to gain a clearer picture of the role of religious institutions in social life. This is among the aims of the doctoral research currently undertaken by Aditia Gunawan.

\subsection{The Huludayeuh Stone}

This inscription is found in situ at dusun Huludayeuh, desa Cikalahang, kecamatan Sumber, kabupaten Cirebon, West Java, about $15 \mathrm{~km}$ to the west of the city of Cirebon, at the coordinates $06^{\circ} 47^{\prime} 046^{\prime \prime} \mathrm{S}, 108^{\circ} 24^{\prime} 205^{\prime \prime} \mathrm{E} .^{43} \mathrm{The}$ inscription was discovered only in the early 1990s (Tony Djubiantono 1994)

devata bakti di hyan "A governor is devoted to the king, the king is devoted to the god, god is devoted to the deified ancestor." The chosen translation might seem arbitrary, but devata generally refers to the well-known deities of Indian origin in this text, mostly in the group called pañcadevata: Íśvara, Brahmā, Mahādeva, Vișnu, and Śiva. In SKK.20-21, these gods are devoted to Batara Seda Niskala (The Immateralized Lord): basana brahma, visnu, isora, mahadeva, siva bakti ka batara, basana indra, yama, baruna, kovera, besavarna, bakti ka batara, basana kusika, garga, mestri, purusa, patañjala, bakti ka batara, sin para devata kabeh pada bakti ka batara seda niskala "when Brahma, Wisnu, Isora, Mahadéwa, Siwa are devoted to the Lord; when Indra, Yama, Baruna, Kowéra, Bésawarna are devoted to the Lord; when Kusika, Garga, Méstri, Purusa, Patanjala are devoted to the Lord - all of gods together are devoted to Batara Seda Niskala." In several other Nusantaran languages, however, devata rather means ancestor, while hyan means god. Cf. discussion in Clavé \& Griffiths forthcoming, 33.3 s.v. devata.

43. In the course of his very early survey of antiquities and religious practices in Cirebon and Kuningan, F.C. Wilsen (1857: 77, 78, 79 and 92, and unnumbered plate) recorded that the term hulu dayeuh (literally meaning "origin of the settlement") was used to designate chopped-off cylindrical stones placed in a village sanctuary (kabuyutan). 
and first published by Hasan Djafar (1991 and 1994). The last mentioned publication contains an eye-copy. A photo of the stone was published in Sejarah Nasional Indonesia (rev. ed., Bambang Sumadio \& Endang Sri Hardiati 2008: 380). We visited the site in June and September 2013, and during our second visit were able to make two estampages which are now part of the EFEO collection in Paris (inventory numbers n. 2309 and n. 2310). Our edition was established using Hasan Djafar's eye-copy and comparing it first with the photos we had taken of the original. Subsequently we reverified our reading based on the EFEO estampages.

\subsubsection{Special features of script and language}

This inscription makes use of a remarkably thick script, lacking the sharpangled ductus that is characteristic of Sundanese script as seen in the Kebantenan and Kawali inscriptions, and is in that sense comparable to the Linggawangi inscription. The aksara ra has a much longer "tail" than we see in any of the other inscriptions (fig. 11a), and the almost box-like shape of $m a$ is even more exceptional (fig. 11b). These untypical palaeographic features accompany some textual features that seem rather un-Sundanese, namely the repeated spelling sya instead of syi and the repeated use of $i k a \dot{n}$ where one would expect $n a$.

\subsubsection{Text and apparatus}

(1) $[\ldots]$ (ra)tu (na)rana, (ta) $[\ldots]$

(2) $[\ldots]$ sri mah(ha)ra(ja) ra(t) $[\mathrm{u}]$

(3) [ha](j)[i] ri pakvan· sya sam ra(t)[u]

(4) [de]vata pun', masa sya

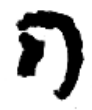

a

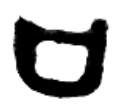

b

Fig. 11 - Palaeographic features of the Huludayeuh inscription.

(5) ṅrətakən· bumi ṅaha-

(6) li<m〉pukən' na bvan 'na

(7) ñuruh sam (di)si suk·laja-

(8) (t)i naRouhkon Ikam ka-

(9) yu si pr`n〉dakah, nalaAn*

(10) na Udubasu, mipati-

(11) kən·n ikam kala

Hasan Djafar (1994) indicates with ellipsis at the beginnings and ends of all lines except line 3 that he supposed an undetermined number of aksaras 


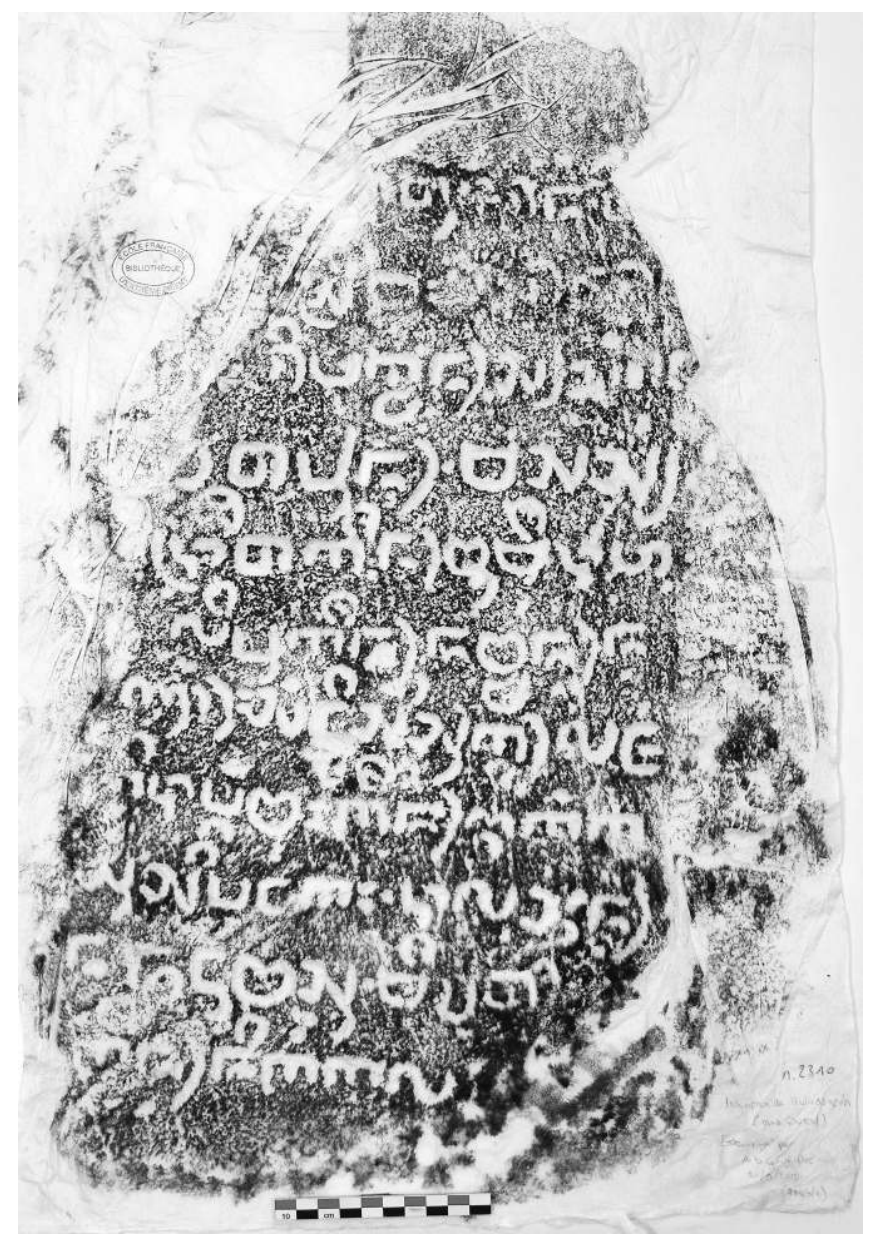

Fig. 12 - The Huludayeuh inscription (estampage EFEO n. 2310).

to have been lost there. This, we feel, is too imprecise. In fact it seems that a rather small number of aksaras is lost, and only in lines $1-4$, because we can read uninterrupted words at the transitions between lines 5-6, 7-8, 8-9 and 10-11. It is not possible to estimate with precision the number of aksaras that might have been lost at the openings of lines 1 and 2 . Finally, we note that the shape of the stone does not suggest that any lines have been lost before the first (partly) preserved line of text.

1. (ina)rana $\diamond$ purana HD. The aksara read as $p u$ by HD is quite faded, but resembles much more closely the $\dot{n} a$ in 1 . 8. Moreover, the vocalization $u$ below the sign to the left is perfectly clear, so it is very hard to suppose the presence of another such vocalization which would be totally invisible right next to it. - 1-2. At the transition 
between these lines, one might restore baduga or prabu. - 3. [ha](j) [i] $\diamond$ in HD's eye-copy, the consonant $j$ is clear, but the estampages do not allow to confirm this reading. Nevertheless, comparison with BaTu.3 strongly suggests that indeed one

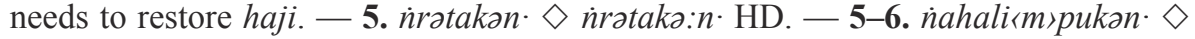
$\dot{n} a h a l i p u_{-} k a n \cdot$ HD. HD notes that some aksaras are lost in a gap between $\dot{n} a h a$ and lipukan due to damage suffered by the end of line 5 and in the beginning of line 6 . But in our opinion, there is no reason to presume any loss of aksaras here at all. - 7 . $\tilde{n} u r u h \diamond \tilde{n} a r a h$ HD. It is clear on the estampage that there are two panyukus. - (disi) suk la ja(ti) $\diamond d \underline{v}$ isi suk laja....i HD. There indeed seems to be some element below the aksara di (cf. HD's $d \underline{v}$ ), but in our opinion it is most likely to be accidental. - $\mathbf{8}$.

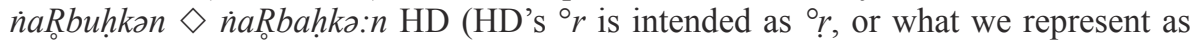
${ }_{\circ}$ ). There is clearly a panyuku. - 8-9. kayu $\diamond k a \ldots s u$ HD. Although damage to the stone has made some part of the left vertical stroke of $y$ disappear, the aksara yu can still be read with certainty. Its width is definitely greater than that expected for $s u$. 9. si $p r\langle n\rangle$ dakah $\diamond$ si padakah HD. We see quite clearly a round stroke under $p$ that must represent $r$. - nalaAn. $\diamond \dot{n}$ ilasan. HD. The shape of $A$ is slightly different than that of $s a$ (cf. sam in line 3) - 10-11. mipatikan. $\diamond$ mipatā... Is' $\cdot$ HD.

\subsubsection{Translation and commentary}

[...] Ratu by name, [...] Sri Maharaja king of kings in Pakuan. He was Sang Ratu Déwata, when he made the world prosperous, made the earth harmonious, [by] ordering the disi Suklajati to fell the widely branching trees, removed Udubasu, killed Kala.

4. masa sya $\diamond$ The word masa has two functions in OS. It can be a noun meaning "time," as in RR.758-759 ulah rea kasauran, hese lamun lain masa "do not waste too many words on it, it is difficult when it is not the proper time." Its second function, which seems to be the one we are dealing with here, is as conjunction "when," usually

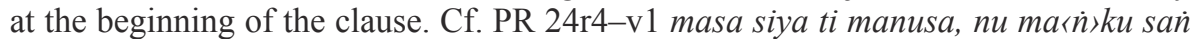

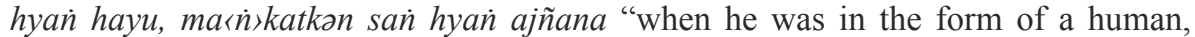
endowed with the holy weal, bringing with him the holy knowledge" and CP.15b rahiyantan vərəh masa siya ti< $\dot{n}\rangle$ gal anak sapilañcəkan "[It is] Rahiyangtang Wereh, when he had left all his children."

5-6. nahali<m〉pukan $\diamond$ The form nahalimpukan is derived from the base halimpu which is still used in MdS, meaning "melodious, sweet-sounding, harmonious (of the voice: not shrill or high-pitched)." It seems that the meaning was broader in OS, not only connected with sound. Cf. SKK.3: lamunna pahi kaopeksa san hyan vuku lima, na bvana boa halimpu "if all five segments had been noticed, the earth would be harmonious"; KP.848-849: hamo ñaho di pamali, moha di sabda nu halimpu "Ignorant about forbidden things, confused about harmonious sound."

7. nuruh $\diamond$ There is no verb nyuruh in MdS, but we find pañuruhan, a nominal derivation from the same base, in SSK.6: jaga ran kəna pañuruhan, mulah mo raksa san hyan siksa kandan karəsian, pakən uran satya di pivaranan "If one has been given the order, one shall not fail to guard the holy precepts from the ascetic milieu, so that one is faithful doing the service."

7. san disi $\diamond$ See below, §4.3.4. 
7-8. suklajati $\diamond$ TB.9v contains a dialogue between Kala and Darmajati. Kala asks: lamun aya viku haji putih suklajati, tərus ajñana, viku vruh (em. vrah ms) tan paguru, viku batan tan pamitra [...], "[I wonder] if there is a royal hermit Suklajati, whose knowledge is penetrating, a hermit who knows without being taught, a solitary hermit without companions?" Then Darmajati replies: oh aya anakin, viku haji putih suklajati, ratu jadi man்uyu "He exists, my child, the white royal hermit Suklajati, the king who became an ascetic." Could there be a connection with the śuklabrahmacāri discussed in some Old Javanese treatises transmitted on Bali? Cf. Ślokāntara 1.5 śuklabrahmacāri naranira, tan parabi sankkan rare, tan mañju tan kumin sira, adyapi təka rin vrddha tuvi sira tan pan்cap arabi sanka pisan "Śuklabrahmacārī is one who has not married since childhood. He is neither averse nor impotent. Even when he comes to old age, he does not marry. He does not talk to women even once" (ed. and trans. Sharada Rani 1957: 35, 76). If so, the disi suklajati would have been a celibate ritual practitioner.

8. narabuhkan $\diamond$ This must be connected with rubuh/roboh in MdS, OJ and Malay. Cf. also rabah in OS and OJ.

9. kayu si pr〈n〉dakah $\diamond$ The reading $p r\langle n\rangle d a k a h$ can be interpreted as equivalent to prandakah, since $-r$ is interchangeable with panyakra in the writing system of West Javanese manuscripts, especially on gebang (e.g., cidro for cidra, Perpusnas L 642 fol. $8 \mathrm{v} 1$ ). The spelling $p a R b u$ for prabu in Kawala.3 shows the reverse phenomenon. The word prandakah can then be interpreted as equivalent to parandakah, i.e. a paderivation from the base randakah that means "spread out widely, branch off widely (of a tree, deer antlers)" in MdS.

9. nalaAn $\diamond$ On the relation between this word and Kala, who figures in line 11 of our inscription, cf. SD.18: madəman kalavisaya, nalaan kala murka, nalabur dudu ti<m>buru "to extinguish the power of Kala, to remove the evil Kala, to dissolve fault and envy." 10. Udubasu $\diamond$ Cf. SC.1105. In OJ contexts, this figure is called Vudubasu. See Pārthayajña 40.8 as cited in OJED, s.v. wudubasu: ndak ajar putunkku ri katattvan in kurukula, ya dumehnya durjana kalā manahnya yan ala, dadinin் surākala lavannikan vudubasu "I will tell you, my grandchild, about the reality of Kuru race, the reason that they became malicious Kāla. When their minds are evil, they are becoming Surākala and Udubasu."

10. kala $\diamond$ According to HD, the text is not completely preserved and after the word kala, which he presumes means "time," an expression of date would follow. Our analysis shows that Kala here means the evil god of that name, and inspection of the stone gives no reason to suspect loss of any text after it. Moreover, several occurrences in OS and OJ literature mention Udubasu and Kāla in the same context.

\subsubsection{Context}

In his article on the inscriptions of the ancient Sundanese kingdoms, Hasan Djafar (1991: 29) advised that "Penelitian lebih lanjut terhadap prasasti baru ini perlu diadakan mengingat kemungkinan implikasinya dalam penulisan sejarah Jawa Barat khususnya masa kerajaan-kerajaan Sunda menjadi amat penting". Our revised reading has started to reveal the global meaning of this inscription, allowing us to analyze its place in the broader context of Sundanese history. 
It has become clear that the inscription mentions the same king as the one who figures in Batutulis and Kebantenan. Hasan Djafar (1994) suspected that the inscription was made during the reign of Surawisésa after Ratu Déwata's death, on the basis of his reading the word purana in the first line and interpreting it as meaning "deceased." We agree that this inscription is postmortem, although our argumentation is based on a different approach (see §5).

The aim of this inscription is not merely to glorify Ratu Déwata for having caused the world to be prosperous, but especially to commemorate how he harmonized it. Ratu Déwata ordered a certain disi to take down trees, drive an evil being Udubasu away, and kill Kala. These three activities can be understood in the context of opening new land.

The word disi is often mentioned as the fourth in a series of five social categories, along with prabu (king), rama (elder), rosi (ascetic), and tarahan (sailor).$^{4}$ Compared with these other terms, the meaning of disi remains rather unclear. Saleh Danasasmita et al. (1987) translate it as "ahli siasat/peramal," and seem to have extrapolated this sense from the Amanat Galungun, in which we find the passage (AG.3r) that they edited as follows: san prabu enak alunguh, san rama enak amanan, san disi jaya pran "the king is at ease sitting [on the throne], the elders are at ease eating, the disis are victorious in war." The Carita Parahyanan contains further useful indications concerning this word, in the passage that we have we cited in §4.2.7. This passage notably suggests that the disi had as duty to allot (naduuman) all kinds of forest tracts, which is clearly compatible with the role that our inscription assigns to the disi called Suklajati. A disi may have been involved in warfare as suggested in the Amanat Galungun, though probably in its ritual aspects. Another Old Sundanese text, the Pabyantaran, contains predictions of the outcome of battle based on natural portents (Mamat Ruhimat et al. 2014: 168-193). In all contexts, it is possible to assume that the disi was a kind of priest in charge of exorcism rituals who seems to have played an essential role in pre-Islamic Sundanese society. Again in the Carita Parahyañan (\$16), Ratu Déwata, the King mentioned in our inscription, is also responsible for opening new

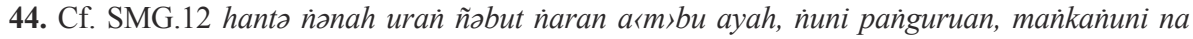
matuha, sañarah inaran san prabu rama rəsi disi tarahan "It is not suitable for us to mention the name of mother, father, and teacher, let alone elders, including the names of kings, village elders, hermits, disi, and seamen (tarahan)"; SMG.15 ini byaktana ma nu kəna ku na kapapaan, di san prabu rama rasi, disi mvan tarahan "this is the explanation of the ones who are affected by the violations with regard to the king, the [village] elders, the hermits, the disis, and the seamen"; SKK.3 ña mana dikan்kə $n 〉 k ə n$ ka nu mava bumi, ya man்upati dadi prabu rama rəsi disi mvan tarahan "The reason why they are being compared to those who are governing the world, [is because] they became manifest as kings, village elders, hermits, disis, and sailors"; SKK.27 san bujanga pagəh di kabujangaanana krəta, san tarahan pagəh di katarahanana krəta, san disi pagah di kadisianana krata "the disciples firm in their discipleship will be successful; seamen firm in their seamanship will be successful; disis firm in their disi-ship will be successful."
} 
territory by filling up a swamp with earth. As this construction took place, there appeared creatures that inhabited the area. One of them is Udubasu:

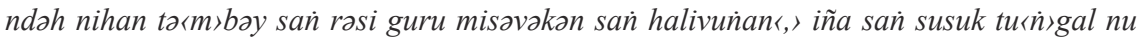

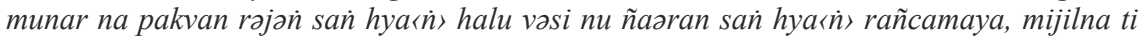

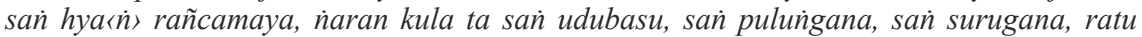

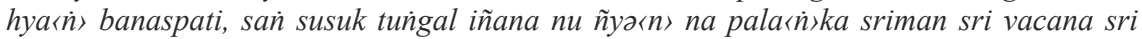
baduga maharaja diraja ratu haji di pakvan pajajaran, nu mikadatvan sri bima untarayana madura suradipati, iña na pakvan san் hyan் sri ratu devata.

As follows is the origin of Sang Resi Guru who had a son [named] Sang Haliwungan. He, Sang Susuk Tunggal, is the one who restored Pakuan, and Sang Hyang Haluwesi is the one who filled up with earth the holy Rancamaya. [They] appear from Rancamaya: "My name is Sang Udubasu, Sang Pulunggana, Sang Surugana, King Hyang Banaspati." Sang Susuk Tunggal is the one who made a palanquin for the illustrious orders (sriman sri vacana) of Sri Baduga Maharaja Diraja, King of kings in Pakuan Pajajaran, the one who has the palace [called] Sri Bima Untarayana Madura Suradipati. There, in Pakuan was the holiness Sri Ratu Déwata.

This passage is essential for establishing the relationship of Ratu Déwata - the very name which is mentioned also in the Huludayeuh inscription with Sang Halu Wesi, who in the Carita Parahyaian is depicted as being in charge of filling up with earth a place called Rancamaya - a toponym known in present-day Bogor. In areas that are about to be built or turned into settlements, it was necessary to hold some ritual to clean the place from evil creatures, among which Udubasu.

Recent Sundanese mythological tradition still knows the name Budug Basu as a mythical figure in the Dewi Sri cycle. He is Sri's brother. One episode narrates how Budug Basu - along with his father, Sapi Gumarang, and his brother, Kalabuat - attacks an agricultural field in Pakuan. Their attacks always fail at the hands of protagonist Sulanjana. In the end, these destructive figures were willing to give in and promised to serve Sulanjana, on the condition that their names should always be invoked, and they should be pleased by the various kinds of plants as a means of offering every time the clearance of agricultural land took place. ${ }^{45}$ Could the name Sulanjana go back to the name Suklajati in this inscription, since it has three syllables in common?

\subsection{The Kawali Stones}

This group of six inscribed stones is preserved in various spots on the site called Astana Gedé at Kawali in kabupaten Ciamis. ${ }^{46}$ Five of them (Kawali 1-5)

45. For studies of the narrative cycle of Dewi Sri in Sundanese culture, see Hidding 1929 (particularly pages 1-18 on the myth of Sulanjana, summarized in Dutch) and Sukanda-Tessier (1977: 71-84). Pleyte provided an edition and translation into Dutch (1907). Satjadibrata (1931), and recently, Kalsum \& Etti Rochaeti (2015) have offered an edition of Wawacan Sulanjana, without however translating the text.

46. For a more detailed description about the site, see Rusyanti (2011). For a physical description 
were already known to scholarship by the beginning of the 19th century, while Kawali VI was only discovered in 1995. Some of these inscriptions had already been observed by Stamford Raffles more than 200 years ago, as recorded in his famous History of Java (1817, II: 58). An account of journeys undertaken in the period 1817-1826 (Olivier 1836-1838, I: 190-191) records as many as 12 inscriptions having been found at Kawali and reproduced by a certain J. H. Domis, and announces that gentleman's plan to publish them. But this number 12 is not confirmed by other sources and we owe the first published decipherment of five inscriptions to R. Friederich (1855: 149-182). Friederich's work was supported by Jonathan Rigg, who himself published the first Sundanese dictionary seven years later (1862) ${ }^{47}$ Netscher (1855) contains a brief mention of the Kawali stone with footprints, left handprint, and the Añana inscription (see §4.4.5). K.F. Holle then improved Friederich's reading (1867a: 450-470). Pleyte (1911, 167 with plate B and appendix 2, p. 197) only read Kawali 1. In the post-independence era, Noorduyn (1976) read the five inscriptions again without giving any translation. Dirman Surachmat (1986) cited the reading and translation of five inscriptions (Kawali 1-5), but excluding Kawali 1b, in his interesting paper on the toponymy around Kawali. Noorduyn (1988) read Kawali $1 \mathrm{~b}$ and provided a translation with comments. Subsequently, Hasan Djafar (1991) read Kawali 1-5 offering a more rigorous diplomatic edition along with an Indonesian translation. Titi Surti Nastiti (1996) gave readings of all the inscriptions on the site, including Kawali 6, which had just been discovered one year earlier. Her readings too are accompanied by an Indonesian translation. Nandang Rusnandar (1999) again included all of the inscriptions, even Kawali 6, but his readings contain many errors so we do not refer to them in our notes. Likewise full of errors are the readings of Machi Suhadi (1999) and Djadja Sukardja S (2002), who each published booklets about the sites and its inscriptions, so that we do not refer to them either in our Apparatus. Richadiana Kartakusuma (2005) re-published the six inscriptions and provided translations into Indonesian. Titi Surti Nastiti \& Hasan Djafar (2016) reproduced the reading from their previous publications. Our reading is based on direct observation of the stones in 2013 and on consultation of the photographs by Isidore van Kinsbergen ${ }^{48}$ as well as those made by Arlo Griffiths.

of the inscriptions, see Titi Surti Nastiti \& Hasan Djafar (2016).

47. On Jonathan Rigg, his life and œuvre, see Atep Kurnia 2011.

48. See Theuns-de Boer \& Asser 2005: 232-233. The relevant numbers are indicated in the table below. The photos of the Kawali inscriptions can be found online at https://digitalcollections. universiteitleiden.nl with the search term "kawali". 


\begin{tabular}{|l|l|}
\hline Kawali 1a & $\begin{array}{l}\text { Friederich 1855 (facsimile by Raden Saleh); photo van Kinsbergen no. 60; } \\
\text { Pleyte 1911; Titi Surti Nastiti 1996; Machi Suchadi 1999 }\end{array}$ \\
\hline Kawali 1b & Friederich 1855 (facsimile by Raden Saleh) \\
\hline Kawali 2 & $\begin{array}{l}\text { Friederich 1855 (facsimile by Raden Saleh); photo van Kinsbergen no. 58; Titi } \\
\text { Surti Nastiti 1996; Machi Suchadi 1999 }\end{array}$ \\
\hline Kawali 3 & $\begin{array}{l}\text { Friederich 1855 (facsimile by Raden Saleh); photo van Kinsbergen no. 59; Titi } \\
\text { Surti Nastiti 1996; Machi Suchadi 1999 }\end{array}$ \\
\hline Kawali 4 & $\begin{array}{l}\text { Friederich 1855 (facsimile by Raden Saleh); photo van Kinsbergen no. 57; Titi } \\
\text { Surti Nastiti 1996; Machi Suchadi 1999 }\end{array}$ \\
\hline Kawali 5 & photo van Kinsbergen no. 56; Titi Surti Nastiti 1996; Machi Suchadi 1999 \\
\hline Kawali 6 & Titi Surti Nastiti 1996; Machi Suchadi 1999 \\
\hline
\end{tabular}

Table 3 - Published visual documentation of the Kawali stones.

\subsubsection{Palaeography}

The script used in the Kawali inscriptions is quite uniform. Some of the aksara shapes differ from those seen in the other inscriptions, and are palaeographically closer to the characters used in pre-Islamic lontar manuscripts from West Java. We can see, for example, the close similarity of the Kawali script with the one used in lontar manuscripts in aksara ya, ra, sa, and also in the panghulu and panolong markers (see the Appendix). De Casparis (1975: 55) has already discussed the forms of ma, ya, sa, ra, A, panghulu, pamepet, and pamaéh. Here we focus on some other interesting features. A number of aksaras are similar to those found in the Kebantenan inscriptions, for example $n a$ (fig. 13a) which is strikingly different from the same character in other inscriptions. The aksara ca in the Kawali 1 corpus has a shape (fig. 13b) which is similar to na in the same inscriptions but with an additional line curved to the right. As in Batutulis and Kebantenan, we also find in Kawa1 a special form of $k$ - (fig. 13c). This form is identical to what we find in lontar manuscripts. Very unique forms are found in the word Iña (fig. 13d) which was misread as bhagya by early scholars. We can recognize this type of $I$ by a slanted line under a double arch. By contrast, the independent vowel $I$ is normally formed by writing $b$ and adding a slanting stroke below (as illustrated in fig. 4c and appendix, table 2). The aksara ña can also be recognized by the separate parenthesis-shaped stroke to the right of a $g a$ shape. In manuscripts, $\tilde{n} a$ is formed by adding such a stroke to the shapes of $b a$ and $y a$. As such, these two features are unique and only exist in the Kawali inscription. Another very striking feature is the absence of any certain panyecek signs on all stones except the lingas. The sound /o/ is also interesting to note, spelled not with the combination panéléng and panolong as in the other OS 
inscriptions, but only with panolong. In Kawali 6, there is a sign that predecessors have read as panolong, which looks like the arabic number 2 on the bottom right of the script concerned. However, we see two types of signs, although the differences are small. We interpret the first form (fig. 13e) as the pasangan va, while the second form (fig. 13f) represents panolong.

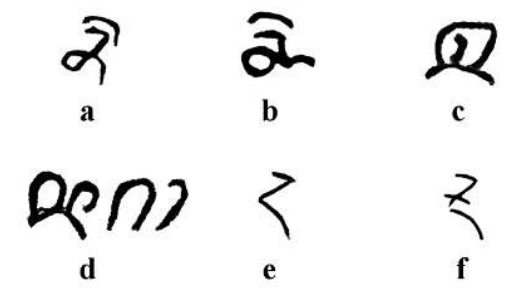

Fig. 13-Palaeographic features of the Kawali inscriptions.

\subsubsection{Kawali 1 a}

This is the text engraved on the main face of the stone.

\subsubsection{Text and apparatus}

(1) +? nihan tapak va-

(2) lar nu syi muliA tapa I-

(3) ña paRou raja vas tu

(4) mañaḍəg · di kuta kava-

(5) li nu mahayu na kaḍatuAn.

(6) suravisesa nu marigi sa-

(7) kulili<m〉 dayəh nu najur sakala-

(8) desa Aya ma nu pa<n>dəri pake na

(9) gave rahhayu pakən· həbəl· ja-

(10) ya di na buAna

1-2. tapak valar N HD TSN $\diamond$ tapa kata F; tapa kavali $\mathrm{P}$; tapa $k>$ kavali $\mathrm{RK} . \mathbf{- 2}$. nu syi muliA tapa $\mathrm{H} \diamond$ nusya muni atapa $\mathrm{F}$; nu sam hyam muliA tapa $\mathrm{P}$; nu siya muliA tapa N RK; nu siya muliA tapa $k>$ HD TSN. - 2-3. Iña $\diamond \mathrm{N}$ HD TSN RK; bhagya F H P. - 6-7. sakulili $\langle\dot{m}>\mathrm{H} \mathrm{N} \diamond$ sakulili F; sakulilim HD TSN RK; it may be doubted that any panyecek was written here - 8. pa〈n〉dəri $\diamond$ padari F; pa〈n〉də:ri H N HD TSN RK; pandə:ri P. - 9. habal $\diamond$ həbə⿱亠䒑 F; hə:bə:l H P N HD TSN RK.

\subsubsection{Translation and commentary}

These are the footprints (tapak valar) of the one of praiseworthy asceticism. $\mathrm{He}$, his majesty king Wastu, ruling in the city Kawali, is the one who beautified 
the palace Surawisésa, who dug a moat around the city, who planted (crops) in all villages. If there is one in the future, he must be observant of (pake) good works, so that success in the world will be long-lasting.

1-2. tapak valar $\diamond$ The word walar-walar is attested in Rigg (1862: 526) "foot-mark, track (of man, animal, etc.) on the ground." We suppose that tapak valar is a kind of redundant compound, of the type tapak lacak (MdS \& MdJ), asal mula, cantik jelita (Malay), etc. Here it probably helps to express plurality.

2. nu syi muliA tapa $\diamond$ We do not understand precisely why Noorduyn \& Teeuw 2006 (Glossary, s.v.) indicate that the expression nu siya has the meaning "venerable, reverend." Surely, its juxtaposition with a third word can yield honorific sense, as in the present context and in CPV.247 nu siya mahapandita "the reverend great teacher," but in all contexts it can be analyzed as equivalent to Malay ia yang. Further examples are SA.927 nu sia laksana bela "the one who carried out the sacrifice," SA.502 nu sia nukus ñamida "those who burn incense and firewood." It can also be used to form epithets, as we see in BM.1181 Nu Siya Laran (litt.: the one who is forbidden) and in the designation used in CP for the last king of Pakuan Pajajaran, viz. Nu Siya Mulya (litt.: the one who is praiseworthy, cf. Malay yang mulia). The latter is very similar to nu siya mulia in our inscription. But here it is followed by the word tapa, so we interpret it as "the one of praiseworthy asceticism," an epithet for King Wastu. See also §4.1.4.

2-3. Iña $\diamond$ On the position of Iña, see Kawa2.2-3.

7-8. sakaladesa $\diamond$ The word sakala, of Sanskrit origin, means "all" here as it does in Sanskrit and in OJ when it is the first member of a compound (OJED s.v. sakala 2). It is surprising that in the OS corpus, this word is only attested with this meaning in this inscription. In manuscripts, we always find sagala in the meaning "all," while sakala usually refers to the "manifest world," as the opposite of niskala, as it does in OJ (OJED s.v. sakala 1$)$.

\subsubsection{Kawali $1 b$}

This is the text on the lateral faces $(1=$ top, $2=$ right, $3=$ bottom, $4=$ left). It was first read by Friederich (1855) and then by Pleyte (1911: 197) but their readings contained numerous mistakes so we exclude them from our apparatus. Our edition, like those of Hasan Djafar (1991) and Titi Surti Nastiti (1996), follows that of Noorduyn (1988: 309-310), which we have found to be flawless by consulting our own photographs. Noorduyn was the first to observe that this text is in verse form.

\subsubsection{Text and apparatus}

(1) hayuA diponah-p(o)nah

(2) hayuA dicavuh-cavu(h)

(3) IA neker Iña Ager

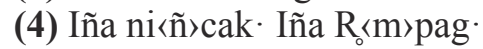


3. IA N HD TSN $\diamond$ Iña RK - Ager N HD TSN $\diamond A(\dot{m})$ ger RK - 4. Iña R $\langle$ (m)pag. $\mathrm{N}$ HD TSN $\diamond I A$ R $\langle$ rm pag. RK.

\subsubsection{Translation and commentary}

It should not be defied / it should not be treated wantonly / anyone striking it will fall prone / anyone kicking it will fall to the ground.

We have accepted Noorduyn's translation which seems perfectly adequate. See also his valuable comments on the translation (1988: 310$)$. We would like to add about the occurrence of $I A$ in line 3 that this word can be understood as iya or $y a$, and can stand as 3rd person pronoun (cf. Keba2.3\&4 on ya standing for $i \tilde{n} a$ ). It is interesting to note that the equivalent word iya appears passim in Amanat Galungun, a text which originates from the eastern part of West Java, and may share dialectal features with the language of the Kawali inscriptions. See for example AG.14: asin iya nu mənan்kə〈n〉 na kabuyutan na galungun, iya sakti tapa, iya jaya pran "whoever is he who acquires the sanctuary of Galunggung, he will be powerful in asceticism, he will be victorious in battle."

\subsubsection{Kawali 2}

\subsubsection{Text and apparatus}
(1) Aya ma
(2) nu ṅəsi I-
(3) ña kavali I-
(4) ni pake na kə-
(5) Rta bənər

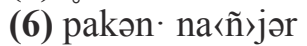
(7) na juritan

2. nu ṅəsi $\diamond n u$ jəh̆ si $\mathrm{F}$; nu $\dot{n} ə: s i \mathrm{H} \mathrm{N}$ HD TSN RK. - 2-3. Iña N HD TSN RK $\diamond$ bhagya $\mathrm{F} \mathrm{H}$ - 3-4. Ini $\mathrm{HD}$ TSN $\diamond$ bari $\mathrm{F} \mathrm{H}$; bani $\mathrm{RK}$.

\subsubsection{Translation and commentary}

If [you] occupy this (place called) Kawali, be observant of the proper behavior, so that [you] remain upright in battle. ${ }^{49}$

6. $n a\langle\tilde{n}>j \partial r \diamond$ Cf. PJ.126: dogdag tañjar jaya pran் "indeed upright, victorious in battle". 7. $n a \diamond$ Cf. di na in Kawala.10 and see our discussion under §3.2.1.

49. Hasan Djafar's translation into Indonesian: "Semogalah ada yang menghuni di Kawali ini yang melaksanakan kemakmuran dan keadilan agar unggul dalam perang." Richadiana Kartakusuma's translation: "Kepada yang mengisi Kawali berani menerapkan kebenaran agar bertahan dalam perjuangan (hidup)." 


\subsubsection{Kawali 3}

One word of uncertain reading. Netscher 1855 read angkana (i.e. An̈kana or Amkana) and interpreted it as "his/her sign." Noorduyn (1976) read Añana. We accept his reading, based on the assumption that it is a spelling variant for ajñana. In OS sources, we often find the letter $j$ being dropped from this word. See e.g. SMG.38 vuku añana "knowledge section," SC.14 manucap kaañanaan "expound the knowledge."

\subsubsection{Kawali 4}

(1) sam hyim lim-

(2) ga hyam

This short text can be translated: "The sacred linga of the ancestor." Note the two spellings of the word hyain. The spelling hyim is also used in Kawa5.

\subsubsection{Kawali 5}

(1) sam hyim limga

(2) bimba

This short text can be translated: "The sacred linga of Bingba (or Bimba)." Titi Surti Nastiti reads bigba and in her translation indicates "Bingba (= Arca)," which implies that she sees a connection with the Sanskrit word bimba "image." This raises questions both about the meaning of linga, and about the history of usage of the panyecek, which would thus stand for $/ \mathrm{m} /$ (rather than usual $/ \mathrm{y} /$ ). It is interesting to note the meanings of hyam "ancestor" and bimba "image" in Kawali 4 and 5. One may wonder whether the difference between ancestors and "Hindu" gods is relevant here (see footnote n. 42), in which case each linga would have been used for worship of a specific type of deity.

\subsubsection{Kawali 6}

This inscription was accidentally discovered on 3 October 1995 by Sopar, the caretaker of the site (Titi Surti Nastiti 1996: 19). A decipherment of the text was published for the first time by Titi Surti Nastiti (1996) and reproduced in Hasan Djafar \& Titi Surti Nastiti (2016), while Richadiana Kartakusuma (2005) offered a slightly different reading.

\subsubsection{Text and apparatus}
(1) •? Ini pəRti $<\dot{\mathrm{m}}>-$
(2) gal· nu Atis -
(3) ti rasa Aya ma nu 


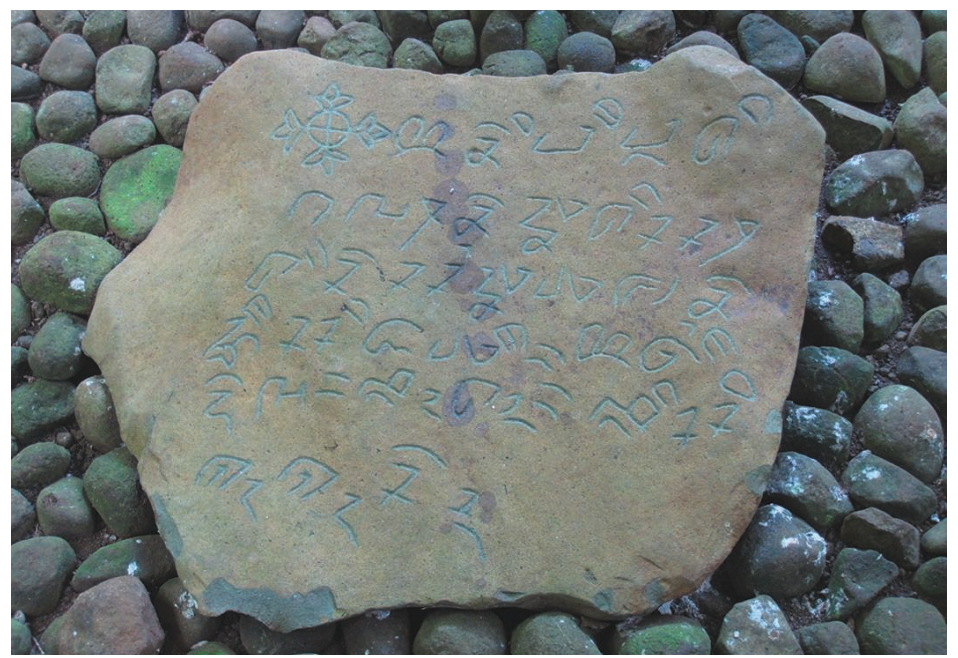

Fig. 14 - Kawali 6 (photo by Arlo Griffiths).

(4) ṅəsi ḍayə̣̣ Ivə

(5) Ulaḥ bvatvaḥ bisi

(6) kvakvaro

1.pəRti $\dot{m}\rangle g a l \cdot$ TSN $\diamond p \partial R t i m g a l \cdot$ RK. - 5. bvatvah $\diamond$ botoh TSN RK. - 6. kvakvaro $\diamond$ kokoro TSN RK.

\subsubsection{Translation and commentary}

This is the relic of those who are of stable emotions (atisti rasa). If one resides here, one should not gamble: it will lead to suffering.

1. $p \curvearrowright$ Roti<m,gal $\diamond$ The prefix pərə-, prə or pra is not commonly used in OS. So far we have encountered prabakti "devotion, worship" and pratapa "ascetic." All instances are nouns, whether designating agents (pratapa) or actions (prabakti). It must be noted that the base tingal in OS (as in MdS and MdJ) never seems to have the meaning "to reside, to live (in a place)" familiar from Malay, but rather means "to be left behind." We have the impression that pratingal here has a meaning similar to MdS titinggal "relic, inheritance" and to that expressed by tapak-valar in Kawa1a. Compare how in Malay the expression jejak has the same meaning as peninggalan.

2-3. Atisti $\diamond$ Cf. SMG.32: nu kaiǹ>kən jon ta ma, na gain atisti pasanta "what is comparable to a seaboat is the stable and peaceful mind." It is not clear whom nu Atisti rasa refers to, whether it is the same as nu sia mulia tapa in Kawala, i.e., King Wastu, another former king (or kings), or the hermit (or hermits). In our opinion, the first and second are the most plausible interpretations. However, the third interpretation need not be incompatible with the other two as kings themselves may be ascetics. Cf. CP11a, 39a, 24b, passages which narrate how several kings became ascetics (narajarasi).

4. ivə $\diamond \mathrm{A}$ variant (as per §3.1.3) of iyz “this, here," MdS ieu. Cf. CP.12r iva keh pamalaan 


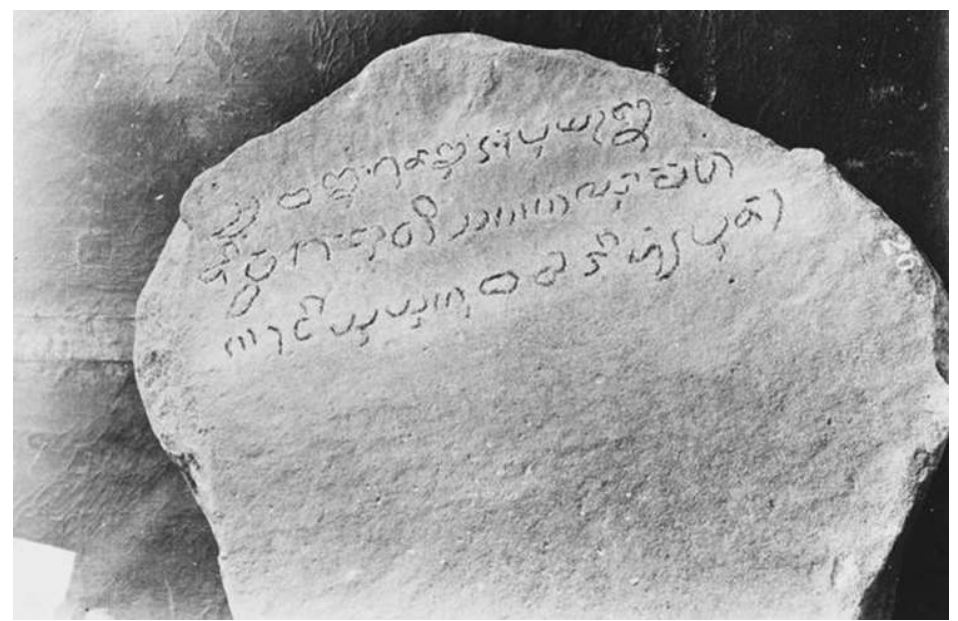

Fig. 15 - The Linggawangi stone (photo OD-1460, courtesy of the Kern Institute collection, Leiden University Library).

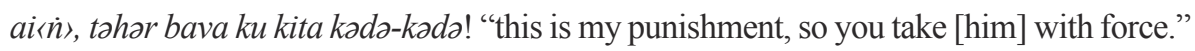
5. Ulah bvatvah $\diamond$ Cf. SMG.15 as quoted under Keba1. Prohibitions of gambling are a common thread seen in late pre-Islamic prescriptive texts and inscriptions from Java and Bali. See Schoettel \& Griffiths, forthcoming.

\subsection{The Linggawangi Stone}

The inscription is kept at the National Museum in Jakarta with the number D. 26. A black and white photograph of this inscription, reproduced here as fig. 9, is available in the series of the former Oudheidkundige Dienst under no. 1460 $(O V, 1912: 84)$, and a color photo accompanies the recent publication by Hasan Djafar et al. 2016: 92-93. In July 1877, the Resident of Priangan sent a letter to the Bataviaasch Genootschap concerning the discovery of this inscription in desa Linggawangi, Tasikmalaya ( $N B G$ 15, 1877: 111, 150, 142; Groeneveldt 1887: 381; Verbeek 1891: 52-53; ROD, 1914: 77, no. 233). In October of the same year, the Bataviaasch Genootschap sent a facsimile of the inscription to Holle with the request to read it. Holle responded immediately, and his reading was published in the same year (Holle 1877). Although Holle mistakenly read the first and last numeral signs expressing the date of the inscription, he still entertained the right conclusion, viz. that the inscription forms a date 1333 Śaka, only to reject it as he thought that his reading didn't allow it. Pleyte (1911: 162) offered a new reading still rather marred by errors but nevertheless accepted the date of 1333, citing a letter from H. Kern. Saleh Danasasmita (1975a) published an extensive analysis, but an error of reading leads to a far-fetched interpretation of the year as 1033 Śaka. Only Hasan Djafar's reading (1991, reproduced in Hasan Djafar et al. 2016) can be relied upon, although the relationship between the numeral signs and the 
chronogram words is not explained because this scholar does not translate the text. We read the text from the OD photo and we discuss the content of the inscription, particularly the interpretation of the chronogram.

\subsubsection{Palaeography}

This short inscription makes use of a rounded script, lacking the sharp-angled ductus that is characteristic of Sundanese script as seen in the Kebantenan and Kawali inscriptions, and is in that sense comparable to the Huludayeuh inscription. The appearance of the aksara ța in the word bațari in the third line is noteworthy. In our corpus, this aksara is only found in the present inscription. It is ubiquitous in gebang and lontar manuscripts, although in the latter, the character also represents the syllable/tra/ (see Aditia Gunawan 2019: 27-28; Rahmat Sopian 2020: 135).

\subsubsection{Text, apparatus and commentary}

(1) (sva)ba 3 guna 3 Apuy 3

(2) di vva(m) 1, Iti sakakala rumata-

(3) $\mathrm{k} \cdot$ disusuku bațāri hyam pun

1. (sva)ba $\diamond / /$ ba HD. See below, $\$ 4.5 .4$ - 2. di vva(m) $\diamond$ divva HD. The position of panyecek is quite unusual, more to the left than in 1.3 hyam. - Iti $\diamond$ The Sanskrit word $i t i$ is used here as equivalent for ini or nihan seen in other OS inscriptions (BaTu.1, Keba1.1r1). - 3. disusuku $\diamond$ understand disusuk ku. On such degemination, see §3.1.5.

\subsubsection{Translation}

Shining 3 qualities 3 fires 3 in man 1: such is the chronogram (or: this is the memorial) of Rumatak being marked off by (the deified female ancestor) Batari Hyang.

\subsubsection{Chronogram}

Although this inscription is short, some problems have so far not been solved, particularly related to the chronogram. First of all, one may ask whether it is intended as a series of independent words or as a sentence. The presence of a preposition $d i$ in the second points to the latter possibility. The problem lies in the initial character of the inscription, before the letter $b a$ and the number 3. Hasan Djafar (1991) considers the sign as an opening mark and transliterates it as //, to which choice it may be objected that no comparable opening mark is found in any other of the inscriptions assembled here. We read it as sva. The aksara $s$ can be recognized by the form of two curved and slanting lines (cf. $s$ in line 2). The pasangan va is recognizable, although it is slightly more tapered here than the pasangan $v a$ in line 2 . Thus, the beginning of the inscription contains the word svaba, a spelling variant, as per §3.1.7, for śvabha or śobha "bright, brilliant, handsome" (OJED, s.v. śobha). This word may then be explained as expressing the same numerical value as $a v a$ or $b a$, words which have a very 
similar lexical meaning (OJED, s.v. awa 2, "bright, clear, shining, glowing") and share the same second syllable. The Old Javanese Pararaton contains a chronogram ba-ba-tanan-von, which expresses the value 1233 (Brandes 1920: 342 , Noorduyn 1993). Whether we read svaba or // ba, the meaning will be the same. Thus, we interpret the sentence svaba guna apuy di vvam as "shining is the nature of the fire in man," the numerical implication of which is explained explicitly by the number signs in the inscription, to be read as per convention in the reverse order, namely 1333 Śaka or 1411/1412 CE.

\section{Implications}

Our study of the Old Sundanese inscriptions has shown how closely they are related to the pre-Islamic Sundanese manuscript tradition. Therefore, the regrettable gap that is noticeable in academic circles today between scholars who read Old Sundanese manuscripts and who study the inscriptions needs to be bridged again, following in the footsteps of Holle, Pleyte, Noorduyn and Saleh Danasasmita. Based on a systematic comparison of epigraphic and manuscript sources, including sources in Old Javanese, we have managed to shed light on several doubtful readings and problems of interpretation. Nevertheless, linguistic, philological, and paleographical aspects of this small epigraphic corpus still leave many gaps to be filled by further research. In this final section, we turn to the broader historical implications of our study.

The only two Saka dates contained in the inscriptions, namely 1333 (Linggawangi) and - although the interpretation of the chronogram remains uncertain - 1455 (Batutulis), furnish a broad chronological framework. It is surely significant that this date range largely falls after the dates associated directly or indirectly with Majapahit rule in East Java. The latest charters issued by the Majapahit kraton are the group of stone inscriptions concerning a freehold ( $\operatorname{sim} a)$ called Trailokyapuri, all of them found near Trowulan in East Java and dated to 1408 Śaka; the last royal inscriptions on copper-plate are those of Waringin Pitu (1369 Śaka) and Pamintihan (1395 Śaka). ${ }^{50}$ All these dates fall in the 15 th century $\mathrm{CE}$. Besides these royal inscriptions, the epigraphic corpus of 15th-century Central and East Java is rich in stone inscriptions apparently unconnected with the kraton but associated with ascetic communities settled in mountain hermitages, notably in the Merapi-Merabu, Lawu, and Bromo-Semeru massifs..$^{51}$

Now compared to this roughly contemporary epigraphic material from relatively nearby regions, the inscriptions we have presented here show surprising differences starting with their material aspects. Not only in size, but also in the engraving technique and (if we may judge from their greater shininess and yellowish color) also in their metallurgical composition, the set

50. These royal inscriptions have been analyzed in magisterial fashion by Noorduyn (1978).

51. These will be presented exhaustively in Schoettel \& Griffiths forthcoming. 
of Kebantenan plates is different from most if not all of the copper plates ever issued from Majapahit or earlier Javanese kratons. None of the stone inscriptions reveal any effort at preparing the stone otherwise than by furnishing a smooth writing surface on one side; this is very different from most Majapahit-period inscriptions, except the non-royal inscriptions found at mountain sites.

It is thus all the more remarkable that in the Sundanese context, all inscriptions do reveal a more or less evident connection with the kraton, although we purposefully do not designate them as "royal" here because their contents show no real similarity with the royal inscriptions of late Majapahit, at the exception of the Kebantenan inscriptions, which have most in common, in form and contents, with the royal inscriptions on copper-plate of late Majapahit. Although none of these plates bears a date, the use of the words susuhunan ayzna di pakuan pajajaran "His Highness now [ruling] at Pakuan Pajajaran" seems to indicate that the plates refer to current events. Moreover, the king expresses himself using a first personal pronoun in sangar kami ratu "the shrine of me, the king." Hence, we can argue that the Kebantenan inscriptions were issued when king Sri Baduga was on the throne (a period we have tentatively accepted may have corresponded roughly to the years 1482-1521 CE).

We emphasize this point, because we believe that this "current" aspect sets the Kebantenan inscriptions apart from all the stone inscriptions. The Linggawangi inscription can be interpreted as recalling an event during the lifetime of a deceased queen (bațāri). The Batutulis inscription quite explicitly states that the king was dead when it was produced. As we have tried to show above, this inscription is a memorial (sakakala) of the deceased king Sri Baduga, probably created during the first half of the 16th century CE. In our opinion, it is also possible to read as a post-mortem memorial the inscription Kawali 1a, which mentions the name of King Wastu. Based on known historical data and on the location of Kawali in the Galuh area of eastern West Java, historians have argued that the King Wastu mentioned in this inscription may be identified as Niskala Wastu Kancana (Pleyte 1911: 165-168; Saleh Danasasmita 1975b). This would make him the father of Déwa Niskala, alias Tohaan in Galuh, and the grandfather of Sri Baduga - it would make him the ancestor of all kings listed in the Carita Parahyanan, and one who supposedly ruled for... 104 years. If we assume this identification to be correct and if we are able to find some way to rationalize this implausible indication of a reign lasting 104 years without affecting the rest of the Carita Parahyanan's chronology, then assuming that the inscription was produced during the king's lifetime would imply that it was engraved at the end of the 14th century, two generations before Sri Baduga.

But these assumptions need to be reconsidered. There are some remarkable textual similarities between two of the Kawali inscriptions and Batutulis. While Batutulis uses the term memorial (sakakala), Kawali 1a mentions the footprints (tapak valar) of King Wastu, and Kawali 6 is said to be a relic (paratingal) for commemoration of nu atisti rasa, which we have argued may 
designate a former king (or former kings). Both in Batutulis and in Kawali 1a we find mention of the king's involvement in delimiting the kingdom's territory: while the term used in Batutulis is nusuk, Kawali 1a uses the practically synonymous term marigi. Although we do not wish to reject altogether the identification of King Wastu in Kawali 1a with Niskala Wastu Kancana of the Carita Parahyanan nor wish to question the entire framework of relative chronology offered by that text, we propose to consider Kawali 1a, and by extension the whole Kawali group, as postdating the reign of Niskala Wastu Kancana, meaning that these inscriptions may have been produced quite some time after his demise, ostensibly around $1475 \mathrm{CE}$.

The most problematic case is the Huludayeuh inscription. Its opening words, which might have given some indication of this text's raison d'être, have been lost due to damage to the stone. However, the text does mention Sang Ratu Déwata alias Sri Baduga. Now was this stone engraved during Sri Baduga's reign, or is this yet another case of post-mortem commemoration? We are inclined to favor the latter interpretation as this text, with its allusions to the opening of forest tracts, seems to share some fundamental characteristics with the way post-Majapahit Javanese historiography frames a picture of the past. ${ }^{52} \mathrm{We}$ therefore propose to assign the Huludayeuh inscription to a period at least some decades after $1521 \mathrm{CE}$.

And so we conclude that much if not all of the Old Sundanese epigraphic corpus is younger than most scholars have so far assumed, that its production does not necessarily cover a range as long as that marked by the earliest and latest dates explicitly recorded (1411 and $1533 \mathrm{CE}$ ), but may entirely be circumscribed to the 16th century (the only possibly earlier items being Linggawangi). This conclusion has important corollaries.

First, with regard to the applicability of the palaeographic method for dating documents. In this article we have tried to examine to what degree the twofold distinction of script types applicable to Old Sundanese manuscripts is pertinent also in the epigraphic context, but from the various subsections on palaeography above, it emerges that the distinction between "Old Sundanese" and "Old Western Javanese quadratic" characters is not evidently pertinent in the epigraphic context and that, in the present state of knowledge, a review of paleography cannot help to narrow down the dating of the inscriptions. Conceivably some progress toward better understanding of this complex issue can still be made through more exhaustive studies of palaeographical aspects of the manuscripts, and comparison with contemporary inscriptions from Central and East Java.

Second, considering the predominant commemorative nature of this epigraphic corpus, we argue that these texts must be read as part of an effort, reflected also in the contemporary redaction of a chronicle, the Carita Parahyanan, to frame a

52. See Van Naerssen (1968: 44) about the Babad Tanah Jawi: "The founding of a new kraton goes together with the clearing of a forest." 
specific picture of the past, namely to create a local Sundanese history, rather than as more or less objective records of contemporary events. This means that there is reason to be careful in their exploitation for writing histoire événementielle, although it seems possible that they were produced sufficiently soon after the events to which they refer to retain some factual validity.

Third, the chronological and discursive context in which we propose to regard these texts naturally leads us to consider the social and political contexts of the Sunda region from the late 15th into the 16th century. The Portuguese records suggest that a Sundanese polity was involved in international commercial exchange, and even signed a trade agreement with a representative of Portugal in $1522 .{ }^{53}$ The impression that some parts of Sunda were well integrated in this period into a cosmopolitan network is reinforced by the travelogue of Bujangga Manik that we have often referred to in the preceding pages. The decades before and after the turn of the 16th century saw momentous political dynamics all around Pakuan Pajajaran. With the fall of Majapahit in East Java and the concomitant rise of Islamic polities first at Demak, and subsequently at Cirebon and Banten, the Sundanese highlands would have become more directly exposed to external pressures. We imagine that it is partly in response to these pressures that Sundanese was raised to the status of a literary language, in a process that led to the production of the inscriptions - alongside the manuscript culture with which they are so intimately connected - that have been our focus here.

Having thus pushed our analysis well beyond the confines of our disciplinary and empirical fields of specialization, we have also reached the limits of what we can say in this contribution. We hope it will help to give the Sunda region a place in the larger picture of early modern Indonesian, Southeast Asian and global history. ${ }^{54}$

53. Hoesein Djajadiningrat (1913: 73-80) presented the Portuguese sources known at his time, and assumed that the "Sunda King" who figures in them was the King of Pakuan. The same sources, and others that were not yet known at the beginning of the 20th century, were analyzed in Guillot 1991. According to the new interpretation proposed by Guillot, the Sundanese polity in question would have been not Pakuan but Banten, which he imagines as a principality nominally subordinate to Pakuan but practically enjoying a substantial degree of autonomy.

54. The above conclusions may be contrasted with the strictly positivist reading of the Old Sundanese sources and their classification in 'Zaman Kuno', i.e. the pre-Islamic period, in Sejarah Nasional Indonesia (Bambang Sumadio \& Endang Sri Hardiati 2008, chapter VII 'Kerajaan Sunda'), or with the total absence of Sundanese-language sources in the seminal study of Southeast Asia in the age of commerce, 1450-1680 by Anthony Reid (1988-1993). 
Appendix: Script tables based on Old Sundanese inscriptions and manuscripts

\section{Consonant aksaras}

\begin{tabular}{|c|c|c|c|c|c|c|c|}
\hline Transliteration & BaTu & Keba & HuDa & Liwa & Kама & $\begin{array}{l}\text { Gclang } \\
\text { SKK }\end{array}$ & $\begin{array}{l}\text { Lontar } \\
\text { SMG }\end{array}$ \\
\hline ka & 0 & $\pi$ & $m$ & (I) & $\pi$ & m & $\rightarrow \rightarrow$ \\
\hline $\mathrm{k}$. & 同 & D & & & $\Omega$ & & $\Rightarrow \nabla^{\circ}$ \\
\hline $\mathrm{ga}$ & $n$ & $\cap$ & & $\cap$ & $n$ & $n$ & $\Rightarrow$ \\
\hline gha & & $m$ & & & & & \\
\hline ṅa & ৫̊く & $\kappa$ & 47 & & 25 & E) & $z$ \\
\hline ca & 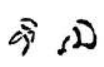 & $\widehat{D}$ & & & 2. & $\pi$ & D) \\
\hline ja & $c$ & $\sigma$ & $E$ & & $\sigma$ & E & 太 \\
\hline ก̃a & m) & $\mathrm{m}$ & $\mathrm{mm}$ & & וח & ब17 & a) \\
\hline ta & a & 0 & ם & u) & 0 & $\sigma$ & דلح \\
\hline ta $\mathrm{a}^{*}$ & & & & $0^{2}$ & & $\$$ & Zूo \\
\hline da & & & C & $a$ & & డ & $\pi$ \\
\hline da & $\sigma_{2}$ & $c$ & & & $\sigma$ & ब & \\
\hline na & r & $\widehat{\alpha}$ & $\sqrt{n}$ & $\alpha$ & 2 & $\pi$ & $\bar{\alpha}$ \\
\hline $\mathrm{pa}$ & $U$ & $\omega$ & U & $\cup$ & $v$ & $\boldsymbol{v}$ & 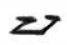 \\
\hline ba & $\infty$ & a) & 0 & 0 & $\approx 0$ & $\theta$ & $\approx$ \\
\hline $\mathrm{ma}$ & $\bar{C}$ & $\theta$ & $\theta$ & 0 & נז־ & 8 & 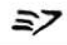 \\
\hline yа & $\omega$ & $\omega$ & $w$ & ש & حاله & ש & zb \\
\hline ra & $\vec{v}$ & 5 & 7) & 5 & $\widehat{R}$ & 5 & $\vec{x}$ \\
\hline la & $\Omega$ & 2 & $\sim$ & 2 & $\sim$ & D & I \\
\hline va & 0 & 0 & & U & $\sigma$ & $\sigma$ & বা \\
\hline sa & $N$ & $\lambda$ & $\boldsymbol{N}$ & ر & $2 x$ & תנ & 27 \\
\hline śa & & ৩ & & & & D & \\
\hline ha & $n$ & מ) & (ת) & $y$ & थ & U & ש7 \\
\hline
\end{tabular}

* This aksara is also used as equivalent for tra. 
2. Vowel aksaras

\begin{tabular}{|c|c|c|c|c|c|c|c|}
\hline Transliteration & BaTu & Keba & HuDa & LiWa & Kawa & $\begin{array}{c}\text { Gebang } \\
\text { SKK } \\
\end{array}$ & $\begin{array}{c}\text { Lontar } \\
\text { SMG }\end{array}$ \\
\hline A & 30 & 3 & $3 ;$ & $s-1$ & $3^{D}$ & $\zeta$ & $3 b$ \\
\hline I & 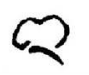 & $\cong$ & $\eta$ & c) & Rp & 89 & कर \\
\hline $\mathrm{U}$ & & 2 & 5 & & & 2 & 云 \\
\hline E & & 5 & & & & $\boldsymbol{6}$ & 30 \\
\hline $\mathrm{O}$ & & 2 & & & & 62 & スス \\
\hline qə & $S^{m}$ & & & & & 3 & 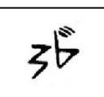 \\
\hline Ro* & 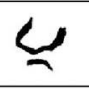 & & 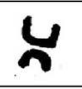 & & $\longleftarrow$ & $y$ & 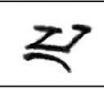 \\
\hline $\mathrm{L}^{* *}$ & & 2 & & & & 2 & 2) \\
\hline
\end{tabular}

* This aksara is equivalent to $r \partial$.

** This aksara is equivalent to la.

\section{Pasangans}

\begin{tabular}{|c|c|c|c|c|c|c|c|}
\hline Transliteration & BaTu & Keba & HuDa & LiWa & Kawa & $\begin{array}{c}\text { Gebang } \\
\text { SKK }\end{array}$ & $\begin{array}{l}\text { Lontar } \\
\text { SMG } \\
\end{array}$ \\
\hline ka & & 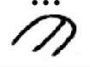 & & & & $\boldsymbol{m}$ & $\rightarrow$ \\
\hline $\mathrm{ca}$ & ort & $\ddot{0}$ & & & & סׁ & $\dddot{2}$ \\
\hline na & & $\ddot{\alpha}$ & & & & $\ddot{~}$ & $\dddot{\alpha}$ \\
\hline ba & & $\ddot{\sim}$ & & & & & $\ddot{\pi}$ \\
\hline va & $\ddot{u}$ & & (j) & $\ddot{0}$ & $\dddot{z}$ & e. & Z \\
\hline
\end{tabular}




\section{Vocalizations and other markers}

\begin{tabular}{|c|c|c|c|c|c|c|c|}
\hline $\begin{array}{c}\text { Term } \\
\text { (transliteration) }\end{array}$ & BaTu & KeBa & HuDa & LiWa & Kawa & $\begin{array}{l}\text { Gebang } \\
\text { SKK }\end{array}$ & $\begin{array}{l}\text { Lontar } \\
\text { SMG }\end{array}$ \\
\hline panghulu (i) & 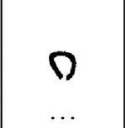 & $\infty$ & Q & a & $\begin{array}{l}n \\
n\end{array}$ & $c$ & $\approx$ \\
\hline pamepet (ə) & $m$ & 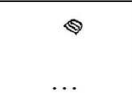 & 9 & & "' & \& & $\begin{array}{l}\text { s } \\
\ldots\end{array}$ \\
\hline panyuku (u) & $\cdots$ & $\cdots$ & 9 & ) & 7 & 3 & $\dddot{7}$ \\
\hline panolong (0) & $6 \ldots 7$ & $\langle\quad\rangle$ & & & $\ldots$ & $6 . . .9$ & ঝ \\
\hline $\begin{array}{l}\text { panolong to mark } \\
\text { vowel length (:) }\end{array}$ & ) & & & & & .9 & \\
\hline $\begin{array}{l}\text { panolong to mark } \\
\text { consonant duplication } \\
\text { (:) }\end{array}$ & & & & & & $\begin{array}{l}9 \\
\ldots 9\end{array}$ & 7 \\
\hline panéléng (e) & 6 & $\measuredangle \quad \ldots$ & & & 2 & $\tau_{\ldots}$ & z... \\
\hline panyecek (m) & - & & $\begin{array}{l}- \\
\cdots\end{array}$ & - & & 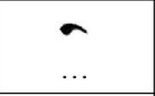 & $\begin{array}{l}\bullet \\
\cdots\end{array}$ \\
\hline pangwisad (h) & & $\ldots$ & $\ldots$ & & $\ldots a$ & $\ldots \neq$ & $\ldots$ \\
\hline panglayar $(\mathrm{r})$ & & 20 & & & 2 & $\begin{array}{l}5 \\
\ldots \\
\end{array}$ & 2 \\
\hline panyakra (r) & l & & & & & & $b^{\cdots}$ \\
\hline pamingkal (y) & $\rho$ & 1) & $j$ & 2 & & תן & ${ }^{\cdots}$ \\
\hline pamaéh (·) & 2 & & ) & 2 & 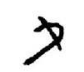 & 9 & Z \\
\hline $\mathrm{r}^{*}$ & & & $\ddot{c}$ & & & $\ddot{\sigma}$ & \\
\hline adeg-adeg (symbols) & $\Theta \Theta$ & 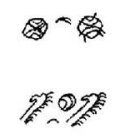 & & & 米 & 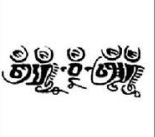 & 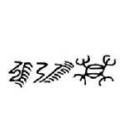 \\
\hline
\end{tabular}

* This is equivalent to $r$. 


\section{Numbers (only in Linggawangi and in manuscripts)}

\begin{tabular}{|c|c|c|c|}
\hline Value & LiWa & $\begin{array}{c}\text { Gebang } \\
\text { SKK }\end{array}$ & $\begin{array}{l}\text { Lontar } \\
\text { SMG }\end{array}$ \\
\hline 1 & $\uparrow$ & $D$ & $\Rightarrow$ \\
\hline 3 & $\vartheta$ & 2 & तर \\
\hline
\end{tabular}

\section{Abbreviations and Sources}

\subsection{General abbreviations}

KUBS Kamus Umum Basa Sunda (Panitia Kamus Sunda 1976)

MNI Museum Nasional Indonesia

NBG Notulen van de Algemeene en Bestuurs-vergaderingen van het Bataviaasch Genootschap van Kunsten en Wetenschappen

MdJ Modern Javanese

MdS Modern Sundanese. Unless stated otherwise, the quoted meanings are taken from Hardjadibrata (2003).

OJ Old Javanese

OJED Old Javanese-English Dictionary (Zoetmulder 1982)

OS Old Sundanese

OV Oudheidkundig Verslag

Perpusnas Perpustakaan Nasional Republik Indonesia

ROD Rapporten van den Oudheidkundigen Dienst

Skt. Sanskrit

\subsection{Designations of inscriptions}

$\mathrm{BaTu}$ Batutulis

$\mathrm{HuDa}$ Huludayeuh

Kawa Kawali

Keba Kebantenan

LiWa Linggawangi

\subsection{Sigla for previous editors}

B Boechari

F Friederich

H Holle

HD Hasan Djafar

P Pleyte 
RK Richadiana Kartakusuma

TSN Titi Surti Nastiti

\subsection{Works of Old Sundanese literature}

AG Perpusnas L 632a, Amanat Galungun, published in Atja \& Saleh Danasasmita 1981a.

BM Bodleian Library, Oxford, Ms.Jav.3, published as Bujangga Manik in Noorduyn \& Teeuw 2006.

CP Perpusnas L 406, Carita Parahyangan, published in Atja \& Saleh Danasasmita 1981b.

CRP Perpusnas L 410 (now lost), Carita Ratu Pakuan, in Atja 1970.

FCP Perpusnas L 406, published as Fragmen Carita Parahyangan in Undang Ahmad Darsa \& Edi S Ekadjati 1995.

JMP L 624b, San் Hyañ Jati Mahapitutur, published in Tien Wartini et al. 2010.

KK Ciburuy no. Cb.Ltr-17, Kavih Katanian, edition in preparation by Ilham Nurwansah.

KP Perpusnas L 419 and L 420, Kawih Paninkes, published as Kosmologi Sunda Kuna in Undang A. Darsa \& Edi S. Ekadjati 2006 (edition based on ms. Perpusnas L 420).

KS Kaputusan San் Hyan், romanized typewriting, ms. Perpusnas no. 280 Peti 89.

PJ Perpusnas L 610, Pituturnin Jalma, published in Tien Wartini et al. 2010.

PR Perpusnas L 1099, Pakeən Raga, published as Sanghyang Tatwa Ajnyana in Tien Wartini et al. 2011b.

CPV Perpusnas L 416 \& L 423, Carita Purnavijaya, published in Pleyte 1914.

RR Museum Sri Baduga 1101, The Sons of Rama and Rawana, in Noorduyn \& Teeuw 2006.

SA Perpusnas L 625, Sri Ajñana, published in Noorduyn \& Teeuw 2006.

SC Perpusnas L 626, San் Hyan் Svavarcinta, published in Tien Wartini et al. 2011a.

SD Perpusnas L 408, Sevaka Darma, in Saleh Danasasmita et al. 1987.

SKK Perpusnas L 630, San் Hyan் Siksa Kandan் Karəsian, published in Atja \& Saleh Danasasmita 1981c, new edition in preparation by Aditia Gunawan.

SMG Perpusnas L 621, San Hyan Sasana Mahaguru, published in Aditia Gunawan 2009, new edition in preparation by the same author.

TB Perpusnas L 620, Tutur Bvana, published in Tien Wartini et al. 2010.

VL Perpusnas L 622, Varugan Lamah, published in Aditia Gunawan 2010.

\section{Secondary literature}

Acri, Andrea. 2017. Dharma Pātañjala: A Śaiva Scripture from Ancient Java, Studied in the Light or Related Old Javanese and Sanskrit Texts. Second Edition. Śata-Pițaka Series 654. New Delhi: International Academy of Indian Culture and Aditya Prakashan. 
Aditia Gunawan. 2009. Sanghyang Sasana Maha Guru dan Kala Purbaka: suntingan dan terjemahan. Jakarta: Perpustakaan Nasional Republik Indonesia.

—. 2010. "Warugan Lemah: pola permukiman Sunda Kuna." In Perubahan Pandangan Aristokrat Sunda dan Essai-essai lainnya mengenai Kebudayaan Sunda, 147-81. Sundalana 9. Bandung: Pusat Studi Sunda.

-. 2015. "Nipah or Gebang? A Philological and Codicological Study Based on Sources from West Java." Bijdragen tot de Taal-, Land- en Volkenkunde 171 (2-3): 249-80.

- 2019. Bhima Svarga: Teks Jawa Kuna Abad ke-15 dan Penurunan Naskahnya. Jakarta: Perpustakaan Nasional Republik Indonesia.

Aditia Gunawan, and Evi Fuji Fauziyah. 2021. "The Particle Ma in Old Sundanese." Wacana: Jurnal Ilmu Pengetahuan Budaya 22 (1) (Languages of Nusantara): 207-223.

Aditia Gunawan, and Arlo Griffiths. 2014. "The Oldest Dated Sundanese Manuscript: An Encyclopedia from West Java, Indonesia." https://www.manuscript-cultures.uni-hamburg. de/mom/2014_03_mom_e.html.

Agustijanto Indrajaya, and Véronique Degroot. 2012. "Prospection archéologique de la côte nord de Java Centre : le district de Batang." Bulletin de l'École française d'ExtrêmeOrient 99: 351-83.

Ajip Rosidi, ed. 1970. Tjarita Děmung Kalagan: dipantunkeun ku Ki Kamal (Lěbakwangi, Kuningan). Bandung: Proyek Penelitian Pantun dan Folklor Sunda.

—. 1973. Carita Lutung Kasarung: dipantunkan oleh Ki Sadjin. Bandung: Proyek Penelitian Pantun dan Folklor Sunda.

- 2000. Ensiklopedi Sunda: alam, manusia, dan budaya termasuk budaya Cirebon dan Betawi. Jakarta: Pustaka Jaya.

Amir Sutaarga. 1965. Prabu Siliwangi, atau Ratu Purana Prebu Guru Dewataprana Sri Baduga Maharadja Ratu Hadji di Pakwan Padjadjaran, 1474-1513: Penelitian sementara. Bandung: Duta Rakjat.

Atep Kurnia. 2011. "Jonathan dari Jasinga.” Karsa, 5 November 2011.

Atja. 1970. Ratu Pakuan: tjeritera Sunda-kuno dari lereng Gunung Tjikuraj. Bandung: Lembaga Bahasa dan Sedjarah.

Atja and Saleh Danasasmita. 1981a. Amanat dari Galunggung: kropak 632 dari Kabuyutan Ciburuy, Bayongbong-Garut. Jakarta: Proyek Pengembangan Permuseuman Jawa Barat.

- 1981b. Carita Parahiyangan: transkripsi, terjemahan dan catatan. Bandung: Proyek Pengembangan Permuseuman Jawa Barat.

—. eds. 1981c. Sanghyang Siksakanda ng Karesian (naskah Sunda Kuno tahun 1518 Masehi). Bandung: Proyek Pengembangan Permuseuman Jawa Barat.

Balogh, Dániel, and Arlo Griffiths. 2020. "DHARMA Transliteration Guide.” https://hal. archives-ouvertes.fr/halshs-02272407.

Bambang Sumadio and Endang Sri Hardiati, eds. 2008. Sejarah Nasional Indonesia. Edisi pemutakhiran. Vol. II: Zaman Kuno. Jakarta: Balai Pustaka.

Barrett Jones, Antoinette M. 1984. Early Tenth Century Java from the Inscriptions: A Study of Economic, Social, and Administrative Conditions in the First Quarter of the Century. Verhandelingen van het Koninklijk Instituut voor Taal-, Land- en Volkenkunde 107. Dordrecht: Foris.

Boechari. 1985-1986. Prasasti Koleksi Museum Nasional, Jilid I. Jakarta: Proyek Pengembangan Museum Nasional, Departemen Pendidikan dan Kebudayaan. 
Bosch, F.D. K. 1941. "Een Maleische inscriptie in het Buitenzorgsche." Bijdragen tot de Taal-, Land- en Volkenkunde van Nederlandsch-Indië 100: 49-53.

Brandes, Jan Laurens Andries. 1920. Pararaton (Ken Arok) of het boek der koningen van Tumapĕl en van Majapahit. Edited by Nicolaas Johannes Krom. Tweede druk bewerkt door Dr. N.J. Krom met medewerking van †Prof. Mr. Dr. J.C.G. Jonker, H. Kraemer en R.Ng. Poerbatjaraka. Verhandelingen van het Bataviaasch Genootschap van Kunsten en Wetenschappen 62. 's-Gravenhage; Batavia: Nijhoff; Albrecht.

Bratakesawa. 1980. Keterangan Candrasengkala. Jakarta: Proyek Penerbitan Buku Sastra Indonesia dan Daerah, Departemen Pendidikan dan Kebudayaan.

Casparis, Johannes Gijsbertus de. 1975. Indonesian Palaeography: A History of Writing in Indonesia from the Beginnings to c. A.D. 1500. Handbuch Der Orientalistik, 3.4.1. Leiden: Brill.

—. 1991. "The Use of Sanskrit in Inscriptions of Indonesia and Malaysia." In Middle IndoAryan and Jaina Studies; Sanskrit Outside India, edited by Colette Caillat, 29-41. Panels of the VIIth World Sanskrit Conference 6/7. Leiden: Brill.

Clavé, Elsa, and Arlo Griffiths. forthcoming. "The Laguna Copperplate Inscription: Java, Luzon and the Notion of a Malay World." In Returning to the Region: Philippine History and the Contingencies of Southeast Asia, edited by Nicole CuUnjieng Aboitiz and Anthony D. Medrano.

Coolsma, Sierk. 1904. Soendaneesche spraakkunst. Leiden: A. W. Sijthoff.

—. 1913. Soendaneesch-Hollandsch woordenboek. 2nd ed. Leiden: A. W. Sijthoff.

Damais, Louis-Charles. 1958. "Études d'épigraphie indonésienne, V: dates de manuscrits et documents divers de Java, Bali et Lombok." Bulletin de l'École française d'ExtrêmeOrient 49: 1-257.

Danadibrata, R. A. 2006. Kamus Basa Sunda. Edited by Ajip Rosidi. 1st ed. Bandung: Panitia Penerbitan Kamus Basa Sunda (Kiblat Buku Utama \& Universitas Padjadjaran).

Dirman Surachmat. 1986. "Kota Kawali: Kajian Toponim.” In Pertemuan Ilmiah Arkeologi IV, Cipanas, 3-9 Maret 1986: proceedings, edited by Pusat Penelitian Arkeologi Nasional, 2b: Aspek Sosial-Budaya:103-12. Jakarta: Departemen Pendidikan dan Kebudayaan, Pusat Penelitian Arkeologi Nasional.

Djadja Sukardja S. 2002. Astana Gede Kawali. 2nd ed. Ciamis: private publication.

Edi S. Ekadjati. 1996. "Cultural Plurality: The Sundanese of West Java." In Illuminations: The Writing Traditions of Indonesia, edited by Ann Kumar and John H. McGlynn, 101-28. New York: Weatherhill \& Lontar Foundation.

Eka Noviana. 2020. "The Sundanese Script: Visual Analysis of Its Development into a Native Austronesian Script.” PhD Thesis. Braunschweig: Institut für Medienforschung Hochschule für Bildende Künste.

Elis Suryani and Undang Ahmad Darsa. 2003. KBSKI: Kamus Bahasa Sunda Kuno-Indonesia. Sumedang.

Emuch Hermansoemantri, A. Marzuki, and Elis Suryani NS. 1987. Kamus bahasa Sunda KunaIndonesia. Bandung: Proyek Penunjang Sundanologi, Dinas Pendidikan dan Kebudayaan, Pemerintah Propinsi Daerah Tingkat I Jawa Barat.

Eringa, F.S. 1984. Soendaas-Nederlands woordenboek: mede met gebruikmaking van eerder door R.A. Kern bijeengebrachte gegevens. Dordrecht: Foris.

Fatimah Djajasudarma, Idin Baidillah, and Undang Ahmad Darsa. 1990. Carita Parahyangan: satu kajian struktur bahasa Sunda dialek temporal. Bandung: Proyek Penelitian dan 
Pengkajian Budaya Sunda (Sundanologi), Dinas Pendidikan \& Kebudayaan, Pemprov Jawa Barat.

Friederich, R. Th. 1853. "Verklaring van den Batoe Toelis van Buitenzorg." Tijdschrift voor Indische Taal-, Land- en Volkenkunde 1: 441-68.

—. 1855. "Ontcijfering der inscriptiën te Kawali, residentie Cheribon." Tijdschrift voor Indische Taal-, Land- en Volkenkunde 3: 149-82.

Goris, Roelof. 1954. Inscripties voor Anak Wungçu. 2 vols. Prasasti Bali diterbitkan oleh Lembaga Bahasa dan Budaja (Fakultet Sastra dan Filsafat) Universitet Indonesia. Bandung: Masa Baru.

Graaf, H. J. de, and Th. G Th. Pigeaud. 1974. De eerste Moslimse vorstendommen op Java: Studiën over de staatkundige geschiedenis van de 15de en 16de eeuw. Verhandelingen van het Koninklijk Instituut voor Taal-, Land- en Volkenkunde 69. 's-Gravenhage: Martinus Nijhoff.

Griffiths, Arlo. 2014a. "Inscriptions of Sumatra, III: The Padang Lawas Corpus Studied along with Inscriptions from Sorik Merapi (North Sumatra) and from Muara Takus (Riau)." In History of Padang Lawas, North Sumatra, II: Societies of Padang Lawas (Mid-Ninth - Thirteenth Century CE), edited by Daniel Perret, 211-53. Cahier d'Archipel 43. Paris: Association Archipel.

-. 2014b. 'Written Traces of the Buddhist Past: Mantras and Dhäran̄īs in Indonesian Inscriptions'. Bulletin of the School of Oriental and African Studies 77 (1): 137-94.

-. 2018. "The Corpus of Inscriptions in the Old Malay Language." In Writing for Eternity: A Survey of Epigraphy in Southeast Asia, edited by Daniel Perret, 275-83. Études Thématiques 30. Paris: École française d'Extrême-Orient.

-. 2020a. "Inscriptions of Sumatra, IV: An Epitaph from Pananggahan (Barus, North Sumatra) and a Poem from Lubuk Layang (Pasaman, West Sumatra)." Archipel: Études interdisciplinaires sur le monde Insulindien 100: 55-68.

—. 2020b. "The Old Malay Mañjuśrīgrha Inscription from Candi Sewu (Java, Indonesia).” In Archaeologies of the Written: Indian, Tibetan, and Buddhist Studies in Honour of Cristina Scherrer-Schaub, edited by Vincent Tournier, Vincent Eltschinger, and Marta Sernesi, 225-62. Series Minor 89. Naples: Università degli Studi di Napoli "L'Orientale".

Griffiths, Arlo, and Pauline Lunsingh Scheurleer. 2014. "Ancient Indonesian Ritual Utensils and Their Inscriptions: Bells and Slitdrums." Arts Asiatiques 69: 129-50.

Groeneveldt, Willem Pieter. 1887. Catalogus der archaeologische verzameling van het Bataviaasch Genootschap van Kunsten en Wetenschappen. Batavia: Albrecht \& Co.

Guillot, Claude. 1991. « La nécessaire relecture de l'accord luso-soundanais de 1522 », Archipel 42: 53-76.

Haan, Frederik de. 1910-1912. Priangan: de Preanger-regentschappen onder het Nederlandsch bestuur tot 1811. 4 vols. Batavia: Bataviaasch Genootschap van Kunsten en Wetenschappen.

Hägerdal, Hans. 2006. "Candrasangkala: The Balinese Art of Dating Events.” Reports from Växjö University: Humanities. Växjö: Växjö University, Faculty of Humanities and Social Sciences, School of Humanities. http://urn.kb.se/resolve?urn=urn:nbn:se:vxu:diva-488.

Hardjadibrata, R. R. 1985. Sundanese: A Syntactical Analysis. Pacific Linguistics, Series D, No. 65; Materials in Languages of Indonesia, No. 29. Canberra: Dept. of Linguistics, Research School of Pacific Studies, Australian National University.

—. 2003. Sundanese English Dictionary. Jakarta; Bandung: PT. Dunia Pustaka Jaya; Kiblat Buku Utama. 
Haris Sukendar. 1985. Peninggalan tradisi megalitik di daerah Cianjur, Jawa Barat. Jakarta: Proyek Penelitian Purbakala, Pusat Penelitian Arkeologi Nasional, Departemen Pendidikan dan Kebudayaan.

Hasan Djafar. 1991. "Prasasti-prasasti dari masa kerajaan-kerajaan Sunda." In Paper from Seminar Nasional Sastra dan Sejarah Pakuan Pajajaran, Bogor 11-13 Nopember 1991, edited by Seminar nasional sastra dan sejarah Pakuan Pajajaran. Bogor.

—. 1994. "Prasasti Huludayeuh." Berkala Arkeologi (Yogyakarta) 14 (Edisi Khusus): 197-202.

—. 2010. Kompleks percandian Batujaya: rekonstruksi sejarah kebudayaan daerah pantai utara Jawa Barat. Bandung : Jakarta: Kiblat Buku Utama; École française d'ExtrêmeOrient; Pusat Penelitian dan Pengembangan Arkeologi Nasional; KITLV-Jakarta.

—. 2011. "Prasasti Batutulis Bogor." Amerta: Jurnal Penelitian dan Pengembangan Arkeologi 29: $1-13$.

Hasan Djafar, et al. 2016. Prasasti Batu: pembacaan ulang dan alih aksara I. Jakarta: Museum Nasional Indonesia.

Hidding, K.A. H. 1929. Nji Pohatji Sangjang Sri. Leiden: Dubbeldeman.

Hoesein Djajadiningrat. 1913. Critische beschouwing van de Sadjarah Bantěn: bijdrage ter kenschetsing van de Javaansche geschiedschrijving. Haarlem: Joh. Enschedé en Zonen.

Holle, Karel Frederik. 1867a. "Vlugtig berigt omtrent eenige lontar-handschriften, afkomstig uit de Soenda-landen, door Raden Saleh aan het Bataviaasch Genootschap van K. en W. ten geschenke gegeven, met toepassing op de inscriptiën van Kwali." Tijdschrift voor Indische Taal-, Land-en Volkenkunde 16: 450-70.

—. 1867b. "Voorloopig bericht omtrent vijf koperen plaatjes, door Raden Saleh gevonden in een offerhuisje bij de kampong Kĕbantěnan, onder Bĕkasih, p. m. 15 paal van Batavia." Tijdschrift voor Indische Taal-, Land- en Volkenkunde 16: 559-67.

-. 1869. "De Batoe Toelis te Buitenzorg." Tijdschrift voor Indische Taal-, Land- en Volkenkunde 17: 483-88.

—. 1872. "De koperen plaatjes van Kĕbantěnan." Tijdschrift voor Indische Taal-, Land- en Volkenkunde 18: 367-69.

—. 1877. "Beschreven steen uit de afdeeling Tasikmalaja, residentie Preanger." Tijdschrift voor Indische Taal-, Land-en Volkenkunde 24: 586-87.

—. 1882a. "De Batoe-Toelis te Buitenzorg." Tijdschrift voor Indische Taal-, Land- en Volkenkunde 27: 90-98.

—. 1882b. "Nog een woord over den Batoe-Toelis te Buitenzorg." Tijdschrift voor Indische Taal-, Land-en Volkenkunde 27: 187-89.

-. 1882c. Tabel van oud- en nieuw-Indische alphabetten: bijdrage tot de palaeographie van Nederlandsch-Indië. Batavia; 's Hage: Bruining; Nijhoff.

Jonker, J.C.G. Een oud-javaansch wetboek vergeleken met indische rechtsbronnen. Leiden: Brill, 1885.

Jurusan Pendidikan Bahasa Daerah, Fakultas Pendidikan Bahasa dan Seni (FPBS), Universitas Pendidikan Indonesia. 2008. Palanggeran éjahan basa Sunda. 4th ed. Bandung: Sonagar Press.

Kalsum and Etti Rochaeti. 2015. Sastra ritual: wawacan Batara Kala \& wawacan Sulanjana. Edisi Pustaka Jaya. Bandung: Pustaka Jaya: Dinas Kebudayaan dan Pariwisata Kota Bandung.

Lokesh Chandra. 1997. "Chanda-Karana: The Art of Writing Poetry.” In Cultural Horizons of India, by Lokesh Chandra. Vol. 6: Studies in tantra and buddhism, art and archaeology, language and literature. New Delhi: International Academy of Indian Culture and Aditya Prakashan. 
Machi Suhadi. 1999. Prasasti-prasasti Kawali dari Ciamis, Jawa Barat. Jakarta: Proyek Pengembangan Media Kebudayaan, Direktorat Jenderal Kebudayaan, Departemen Pendidikan dan Kebudayaan.

Mamat Ruhimat, Aditia Gunawan, and Tien Wartini. 2014. Kawih Pangeuyeukan: tenun dalam puisi Sunda Kuna dan teks-teks lainnya. Seri naskah kuna Nusantara 11. Jakarta: Perpustakaan Nasional Republik Indonesia bekerjasama dengan Pusat Studi Sunda.

Monier-Williams, M. 1872. A Sanskrit-English Dictionary: Etymologically and Philologically Arranged with Special Reference to Cognate Indo-European Languages. Oxford: Clarendon Press.

Molen, Willem van der. 1983. Javaanse tekstkritiek: een overzicht en een nieuwe benadering geïllustreerd aan de Kunjarakarna. Verhandelingen van het Koninklijk Instituut voor Taal-, Land- en Volkenkunde 102. Dordrecht: Foris.

Müller-Gotama, Franz. 2001. Sundanese. Languages of the World. Materials 369. München: LINCOM Europa.

Munawar Holil and Aditia Gunawan. 2010. "Membuka peti naskah Sunda Kuna di Perpustakaan Nasional RI: upaya rekatalogisasi." In Perubahan pandangan aristokrat Sunda dan essai-essai lainnya mengenai kebudayaan Sunda, 103-46. Sundalana 9. Bandung: Pusat Studi Sunda.

Naerssen, Frits Herman van. 1941. Oudjavaansche oorkonden in Duitsche en Deensche verzamelingen. $\mathrm{PhD}$ thesis, Leiden.

—. 1968. "Ancient Javanese Recording of the Past." Arts: The Journal of the Sydney University Arts Association 5: 30-46.

Nandang Rusnandar. 1999. "Prasasti Kawali VI." Kawit (Bulletin Kebudayaan Jawa Barat) 52: 85-95.

Netscher, E. 1855. "Indrukken van voeten op steenen." Tijdschrift voor Indische taal-, land- en volkenkunde 4: 460-64.

Nita Sasmita. 1955. Ngaraksa pusaka Adji Saka aksara Sunda. 2nd ed. Bandung: Pustaka Star. Noorduyn, Jacobus. 1959. "Batu Tulis di Bogor.” Majalah Kebudayaan 11: 504-7.

-. 1962. "Over het eerste gedeelte van de Oud-Soendase Carita Parahyangan (met 5 afbeeldingen)." Bijdragen tot de Taal-, Land-en Volkenkunde 118: 374-83.

—. 1976. "Preliminary Report on Archaeological Research Conducted in West Java and East Java in June, July and August 1976." Leiden: KITLV archives.

—. 1978. "Majapahit in the Fifteenth Century." Bijdragen tot de Taal-, Land- en Volkenkunde 134 (2-3): 207-74.

-. 1982. "Bujangga Manik's Journeys through Java: Topographical Data from an Old Sundanese Source." Bijdragen tot de Taal-, Land- en Volkenkunde 138 (4): 413-22.

—. 1988. "Holle, Van Der Tuuk, and Old Sundanese Epigraphy: The Cikajang and Kawali Inscriptions." Bulletin de l'École française d'Extrême-Orient 77: 303-14.

—. 1993. "Some Remarks on Javanese Chronogram Words: A Case of Localization." Bijdragen tot de Taal-, Land-en Volkenkunde 149 (2): 298-317.

Noorduyn, Jacobus, and Andries Teeuw. 2006. Three Old Sundanese Poems. Bibliotheca Indonesica 29. Leiden: KITLV Press.

Nothofer, Bernd. 1975 The Reconstruction of Proto-Malayo-Javanic. Verhandelingen van het Koninklijk Instituut voor Taal-, Land- en Volkenkunde 73. 's-Gravenhage: Nijhoff.

Olivier, J. 1836. Tafereelen en merkwaardigheden uit Oost-Indië. Amsterdam: Beyerinck.

Oosting, Hendrik Jan. 1884. Soendasche grammatica. 's-Gravenhage : Amsterdam: Nijhoff; 
Müller.Panitia Kamus Sunda. 1976. Kamus umum basa Sunda. Bandung: Lembaga Basa jeung Sastra Sunda.

Pigeaud, Theodoor Gautier Thomas. 1960-1963. Java in the 14th Century: A Study in Cultural History. The Nāgara-Kèrtāgama by Rakawi, Prapañca of Majapahit, 1365 A.D. Third edition, Revised and Enlarged by some contemporaneous texts, with Notes, Translations, Commentaries and a Glossary. 5 vols. Koninklijk Instituut voor Taal-, Landen Volkenkunde Translation Series 4. The Hague: Martinus Nijhoff.

Pleyte, Cornelis Marinus. 1907. Wawatjans Soelandjana: nja eta tjarita tatanen djaman koena. Bandoeng: Kolff.

—. 1911. "Het jaartal op den Batoe-toelis nabij Buitenzorg: eene bijdrage tot de kennis van het oude Soenda." Tijdschrift voor Indische Taal-, Land- en Volkenkunde 53: 155-220.

—. 1914a. "Een pseudo-Padjadjaransche kroniek: derde bijdrage tot de kennis van het oude Soenda." Tijdschrift voor Indische Taal-, Land- en Volkenkunde 56: 257-80.

—. 1914b. "Poernawidjaja's hellevaart of de volledige verlossing: vierde bijdrage tot de kennis van het oude Soenda." Tijdschrift voor Indische Taal-, Land-en Volkenkunde 56: 365-441.

—. 1916. "Mahārāja Çrī Jayabhūpati: Sunḍda's oudst bekende vorst A. D. 1030, Vijfde bijdrage tot de kennis van het oude Soenda." Tijdschrift voor Indische Taal-, Land- en Volkenkunde 57: 201-18.

Poerbatjaraka, R.Ng. 1919-1921. "De Batoe Toelis bij Buitenzorg." Tijdschrift voor Indische Taal-, Land-en Volkenkunde 59: 380-418.

—. 1922. "De inscriptie van het Mahākșobhya-beeld te Simpang (Soerabaya)." Bijdragen tot de Taal-, Land-en Volkenkunde van Nederlandsch-Indië 78: 426-62.

Raffles, Thomas Stamford. 1817. The History of Java. 2 vols. London: Printed for Black, Parbury, and Allen, Booksellers to the Hon. East-India Company [...] and John Murray $[\ldots]$.

Rahmat Sopian. 2020. "Old Sundanese Script in Kabuyutan Ciburuy Manuscripts." Language, Area and Culture Studies 26: 117-48.

Richadiana Kartakusuma. 2005. "Situs Kawali: ajaran Sunda dalam tradisi megalitik?" In Islam dalam Kesenian Sunda dan kajian lainnya mengenai Budaya Sunda, 42-54. Seri Sundalana 4. Bandung: Pusat Studi Sunda.

Reid, Anthony. 1988-1993. Southeast Asia in the age of commerce, 1450-1680. 2 vols. New Haven: Yale University Press.

Ricklefs, M. C. 1999. “Time and Time Again in Java.” History Today, October 1999: 34-41.

—. 2001. A History of Modern Indonesia since c. 1200. 3rd ed. Basingstoke: Palgrave.

Rigg, Jonathan. 1862. A Dictionary of the Sunda Language of Java. Verhandelingen van het Bataviaasch Genootschap van Kunsten en Wetenschappen 29. Batavia: Lange \& Co.

Robins, Robert Henry. 1983. Sistem dan struktur bahasa Sunda. [Bilingual ed.]. Seri ILDEP 12. Jakarta: Djambatan.

Rusyanti. 2011. "Melacak jejak permukiman di Kawali." In Arkeologi: strategi adaptasi, permukiman, dan pemanfaatannya, edited by Kreno Yulianto, 1st ed., 123-38. Jatinangor, Sumedang, Bandung: Alqaprint Jatinangor.

Saleh Danasasmita. 1973. Ya nu nyusuk na Pakwan: prasasti Batutulis Bogor. Vol. 3. Seri monografi. Bandung: Lembaga Kebudayaan Universitas Padjadjaran.

—. 1975a. Hubungan antara Sri Jayabhupati dengan Prasasti Gegerhanjuang. Seri monografi Lembaga Kebudayaan Universitas Pajajaran 1. Bandung: Lembaga Kebudayaan Universitas Padjadjaran. 
-. 1975b. Masalah transkripsi prasasti Batutulis (Bogor) dan tradisi megalitiknya. Serie monografi 8. Bandung: Lembaga Kebudayaan Universitas Pajajaran.

-. 2003. Nyukcruk sajarah Pakuan Pajajaran jeung Prabu Siliwangi. Seri Girimukti. Bandung: Kiblat Buku Utama.

—. 2006. "Mencari Gerbang Pakuan." In Mencari Gerbang Pakuan dan kajian lainnya mengenai budaya Sunda, 11-41. Seri Sundalana 5. Bandung: Yayasan Pusat Studi Sunda.

Saleh Danasasmita and Anis Djatisunda. 1986. Kehidupan masyarakat Kanekes. Bandung: Bagian Proyek Penelitian dan Pengkajian Kebudayaan Sunda (Sundanologi), Direktorat Jendral Kebudayaan, Departemen Pendidikan dan Kebudayaan.

Saleh Danasasmita, Ayatrohaedi, Tien Wartini, and Undang Ahmad Darsa. 1987. Sewaka Darma (Kropak 408), Sanghyang Siksakandang Karesian (Kropak 630), Amanat Galunggung (Kropak 632): transkripsi dan terjemahan. Bandung: Bagian Proyek Penelitian dan Pengkajian Kebudayaan Sunda (Sundanologi), Direktorat Jenderal Kebudayaan, Departemen Pendidikan dan Kebudayaan.

Satjadibrata, Raden. 1931. Wawatjan Soelandjana. Serie Bale poestaka 510. Batavia: Bale poestaka.

Schnitger, F. M. 1939. “Les terrasses mégalithiques de Java.” Revue des arts asiatiques 13 (3): 101-14.

Schoettel, Marine, and Arlo Griffiths. forthcoming. "Ascetic Life in the Mountains as Witnessed by Old Javanese Inscriptions of the Majapahit Period."

Sharada Rani. 1957. Ślokãntara: An Old Javanese Didactic Text, Critically Edites and Annotated. Śata-Pițaka Series (Dvīpāntara-Pițaka), 2 (2). Nagpur: International Academy of Indian Culture.

Stein Callenfels, P.V. van. 1926. Epigraphica Balica I. Verhandelingen van het Koninklijk Bataviaasch Genootschap van Kunsten en Wetenschappen 66 (3). Batavia: Kolff \& Co.

Sukanda-Tessier, Viviane. 1977. Le triomphe de Sri en pays soundanais : étude ethnophilologique des techniques et rites agraires et des structures socio-culturelles. Publications de l'École française d'Extrême-Orient 101. Paris: École française d'Extrême-Orient.

Theuns-de Boer, Gerda, and Saskia E. Asser. 2005. Isidore van Kinsbergen (1821-1905): Fotopionier en theatermaker in Nederlands-Indië / Photo Pioneer and Theatre Maker in the Dutch East Indies. Zaltbommel, Leiden, Amsterdam: Aprilis, KITLV Press, Huis Marseille.

Tien Wartini, Mamat Ruhimat, and Aditia Gunawan. 2011a. Sanghyang Swawarcinta: teks dan terjemahan. Jakarta: Perpustakaan Nasional Republik Indonesia \& Pusat Studi Sunda.

—. 2011b. Sanghyang Tatwa Ajnyana: teks dan terjemahan. Jakarta: Kerjasama Perpustakaan Nasional RI dan Pusat Studi Sunda.

Tien Wartini, Ruhaliah, Rahmat Sopian, and Aditia Gunawan. 2010. Tutur Bwana dan empat manta Sunda Kuna. Jakarta: Kerjasama Perpustakaan Nasional RI dan Pusat Studi Sunda.

Titi Surti Nastiti. 1996. "Prasasti Kawali." Jurnal Penelitian Balai Arkeologi Bandung 4: 19-37.

Titi Surti Nastiti and Hasan Djafar. 2016. "Prasasti-prasasti dari masa Hindu Buddha (abad ke-12-16 Masehi) di kabupaten Ciamis, Jawa Barat." Purbawidya: Jurnal Penelitian dan Pengembangan Arkeologi 5 (2): 101-16.

Titik Pudjiastuti. 2015. Menyusuri jejak Kesultanan Banten. Jakarta: Wedatama Widya Sastra.

Tony Djubiantono. 1994. "Studi geomorfologi atas situs Huludayeuh dan Gunung Singkil di kabupaten Cirebon, Jawa Barat.” Jurnal Balai Arkeologi Bandung 1: 59-66.

Undang Ahmad Darsa. 1998. "Sang Hyang Hayu: kajian filologi naskah bahasa Jawa Kuno di Sunda pada abad XVI.” Magister thesis, Bandung: Universitas Padjadjaran. 
Undang A. Darsa and Edi S. Ekadjati. 1995. Fragmen Carita Parahyangan dan Carita Parahyangan (Kropak 406). Seri penerbitan naskah Sunda 1. Jakarta: Yayasan Kebudayaan Nusantara.

-. 2006. Gambaran Kosmologi Sunda (kropak 420); Silsilah Prabu Siliwangi, Mantera Aji Cakra, Mantera Darmapamulih, Ajaran Islam (kropak 421); Jatiraga (kropak 422): studi pendahuluan, transliterasi, rekonstruksi, suntingan, dan terjemahan teks. Bandung: Kiblat Buku Utama.

Verbeek, R.D.M. 1891. Oudheden van Java: Lijst der voornaamste overblijfselen uit den hindoetijd op Java, met eene oudheidkundige kaart. Verhandelingen van het Bataviaasch Genootschap van Kunsten en Wetenschappen 46. Batavia; 's-Hage: Landsdrukkerij; Nijhoff.

Vogel, J.Ph. 1925. "The earliest Sanskrit inscriptions of Java." In Publicaties van den Oudheidkundigen Dienst in Nederlandsch-Indië, 15-35. Batavia.

Waruno Mahdi. 2005. "Old Malay." In The Austronesian Languages of Asia and Madagascar, edited by Alexander Adelaar and Nikolaus P. Himmelmann, 182-201. London: New York: Routledge.

Wilde, Andries de. 1841. Nederduitsch-Maleisch en Soendasch woordenboek, benevens twee stukken tot oefening in het Soendasch. Amsterdam: Müller.

Wilkinson, Richard James. 1959. A Malay-English Dictionary (Romanised). 2 vols. London; New York: MacMillan \& Co; St Martin's.

Wilsen, F.C. 1857. 'Bijgeloovigheden van de Soendanezen'. Tijdschrift voor Indische taal-, land- en volkenkunde 6: 57-96.

Zakariya Pamuji Aminullah. 2019. "Candrakirana: présentation du texte avec étude de sa première partie consacrée entre autres aux structures métriques.” Paris: École pratique des hautes études (Paris).

Zoetmulder, P.J. 1950. De taal van het Adiparwa: Een grammaticale studie van het Oudjavaans. Reprint 1983, Dordrecht [etc.]: Foris Publications.

—. 1982. Old Javanese-English Dictionary. 2 vols. 's-Gravenhage: Martinus Nijhoff. 
